\title{
Price transmission in international rice markets
}

\author{
Dissertation \\ to obtain the $\mathrm{Ph}$. D. degree in the \\ International Ph. D. Program for Agricultural Sciences in Göttingen (IPAG) \\ at the Faculty of Agricultural Sciences, \\ Georg-August-Universität Göttingen, Germany
}

presented by

\section{Nelissa Jamora}

born in the Philippines

Göttingen, July 2014 
D7

Referee: Stephan von Cramon-Taubadel

Co-referee: Bernhard Brümmer

Date of oral examination: 14 July 2014 


\section{Summary}

The study analyzes price transmission in international rice markets in the last 12 years, covering the period before and after the 2008 food crisis. To this end, it provides empirical evidence of price transmission between the international and domestic markets of rice using price series from January 2000 to December 2012 and contributes to the literature in two aspects. First, it examines export prices that can serve as international reference price in price transmission analysis in order to answer an important question: what is the world price for rice? Second, it explores the role of thresholds, as caused by trade costs, in spatial price relationships from world-to-domestic rice markets using an improved estimation technique for threshold models. We are not aware of publications in price transmission analysis which addresses the two points using a consistent set of price data for a large number of countries. We also characterize the dynamics of price relationships between world to domestic markets across geographical regions and by sample period (pre- and post-2008 food crisis).

The first paper uses linear cointegration procedures to analyze price relationships on international rice markets and provide an overview of price transmission patterns in 269 markets from 58 countries, synthesizing results by rice type. Key results show that export prices for indica rice in Vietnam are linked to the largest number of rice markets worldwide, but no single export price strongly dominates and many domestic prices are linked to more than one export price. Hence, there is no single export price that can be considered as the international reference price for rice. The first paper highlights the importance of differentiating between rice types in order to identify world to domestic price linkages accurately.

The second paper models price relationship between international and domestic rice markets in 47 net-importing countries using an improved regularized Bayesian threshold estimator for threshold vector error correction models. We observe an increase in the magnitude of thresholds and a decline in the speed of price transmission over the sample period. The former suggests that trade costs in international rice trade have increased in recent years; the latter points to some decoupling of domestic and international markets. Overall, our results are consistent with the theory of spatial arbitrage in the presence of trade costs. Some violations for individual countries may be attributed to policy interventions implemented during the 2008 food price crisis.

The results for domestic markets in the Philippines are discussed in chapter 5. Rice is the most important commodity in the country and the Philippines is one of the top importers of rice in the world. We confirm that PT from world to domestic markets in the Philippines has been restricted, particularly after the 2008 food crisis. Trade distortions, e.g., import tariffs, sales tax, and import quotas, largely explain the wide price margins between domestic and international markets.

In the last section, we discuss some implications of the key findings. The results indicate slower price transmission in the period of wider price margins for countries that implemented certain policies during the 2008 food price crisis. Understanding price dynamics in various policy settings could help estimate the welfare impacts of such interventions. Policy makers should also consider ways in reducing trade costs between world and domestic rice markets. 


\section{Acknowledgement}

I am grateful for the supervision and mentorship of Stephan von Cramon-Taubadel. Working with him was a big reason why I moved to Germany and I have no regrets.

I appreciate the valuable feedback I received from Bernhard Brümmer as co-referee, from Matin Qaim as speaker of the RTG, and from Rico Ihle as my third examiner. Special thanks go to Friederike Greb for sharing her intellectual property and statistical skills; to my junior and senior colleagues at GlobalFood and at the Chair of Agricultural Policy; and to the German Research Foundation (DFG) for the travel and research funds.

I give credit to the following people who have advised me throughout my graduate studies: Randy Barker (Cornell), Richard Bernsten (MSU), Mywish Maredia (MSU), Scott Swinton (MSU), Nicholas Minot (IFPRI), Sergiy Zorya (WB), Iain Shuker (WB), David Dawe (FAO), and Piedad Moya (IRRI).

Many thanks go to Antje Wagener, Melanie Grosse, Kathrina Gonzales, and the „Hiwis“ for the research support and to my Filipino friends in Göttingen (and nearby towns) for making us feel at home in Germany. To my family and friends from Asia, North America, and Europe, thank you for your love and support.

For letting me pursue my aspirations across the globe, I am especially indebted to my family -- JJ, Luis, Nanay Lisa, and Lola Tess.

All glory to God. 


\section{Table of contents}

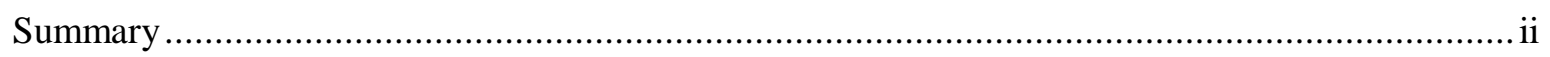

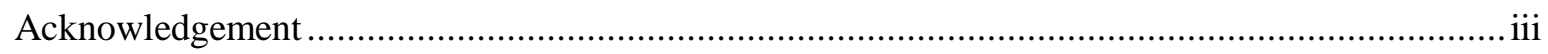

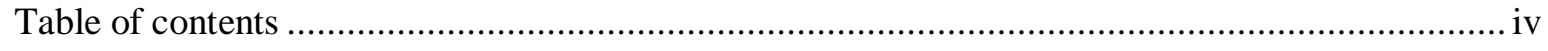

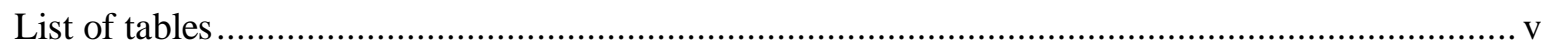

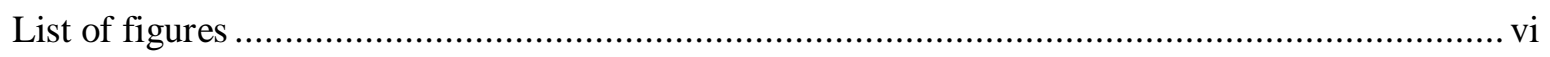

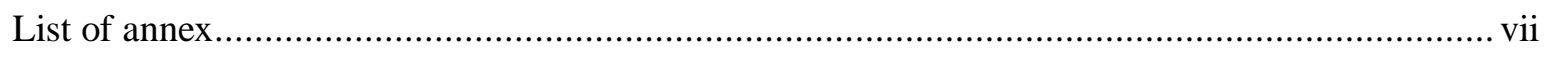

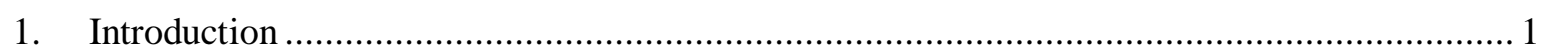

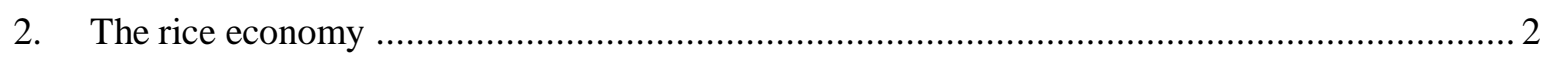

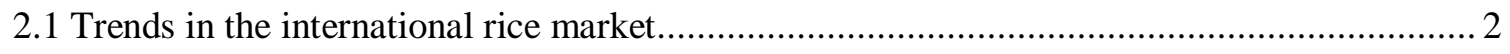

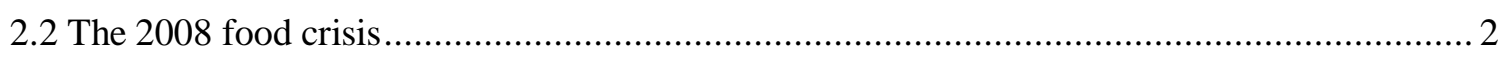

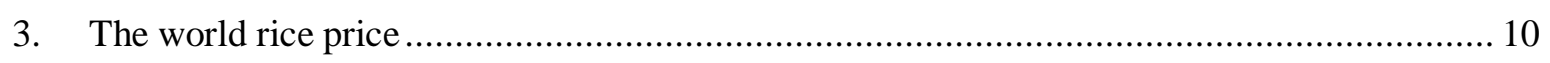

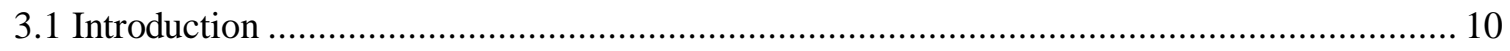

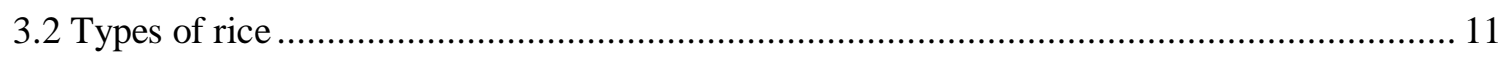

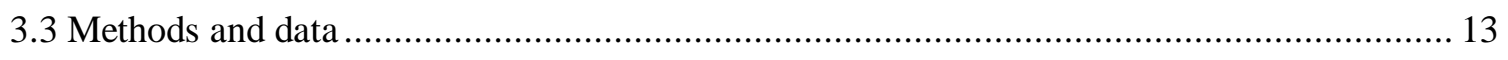

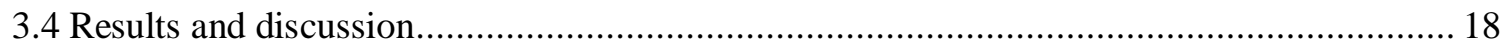

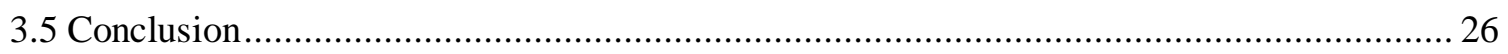

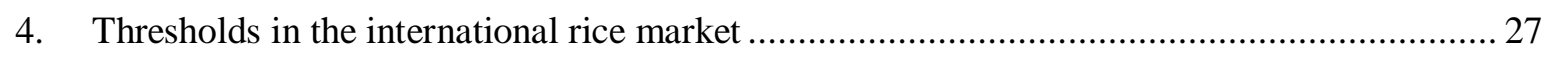

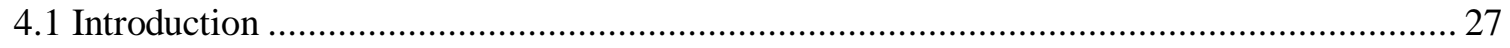

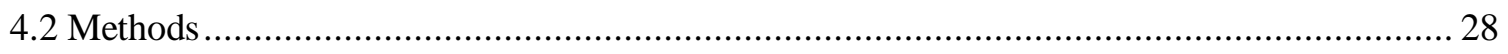

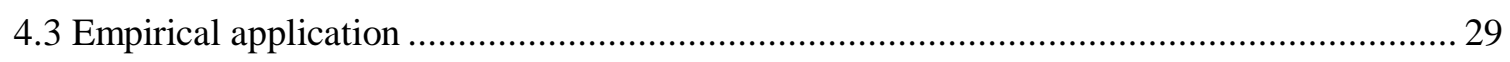

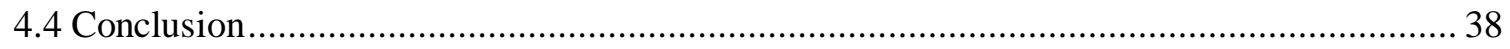

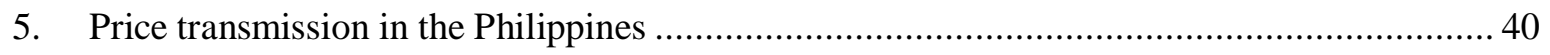

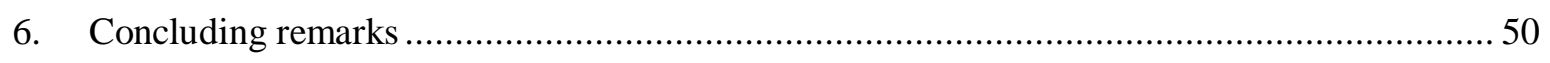

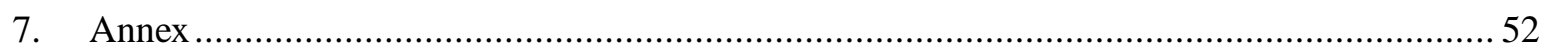

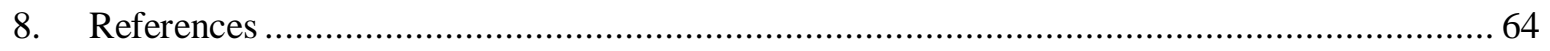




\section{List of tables}

Table 1. Global average production, area, and exports of grains, 1960 to 2010 ................................ 4

Table 2. Top 10 rice producers and consumers, values in decreasing order, 2012 ............................ 4

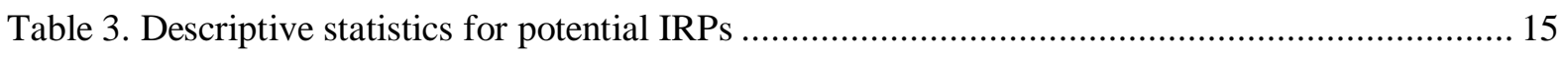

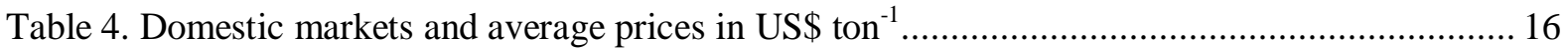

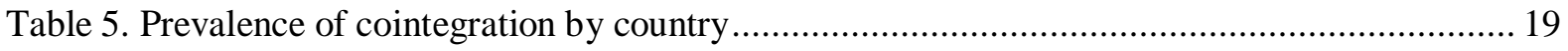

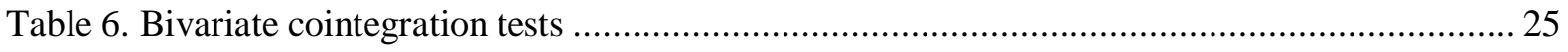

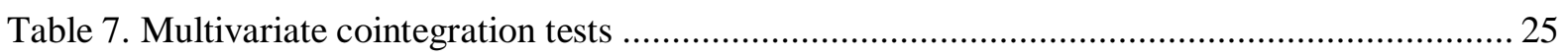

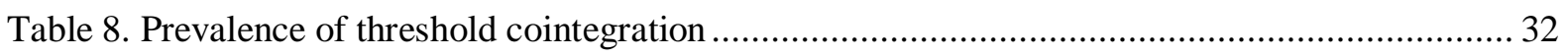

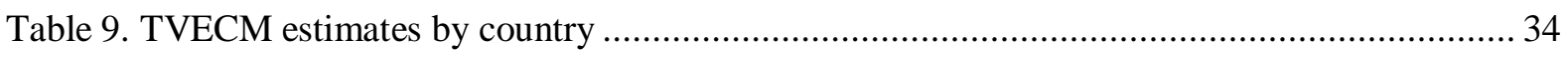

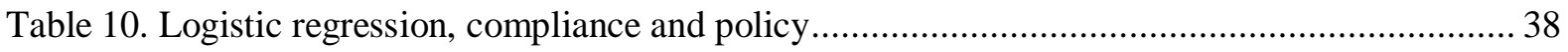

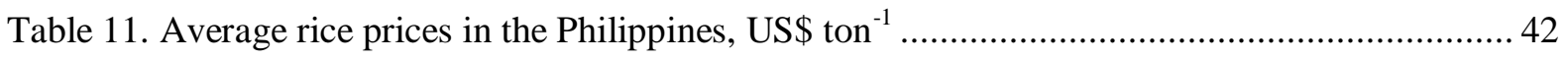

Table 12. Prevalence of linear cointegration in domestic markets in the Philippines ........................ 44

Table 13. Prevalence of threshold cointegration in the Philippines .................................................. 45

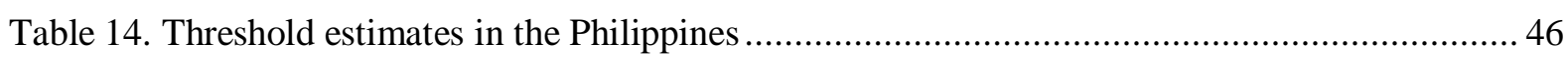




\section{List of figures}

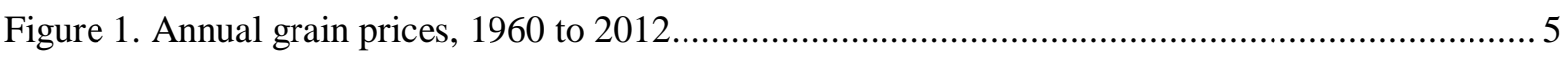

Figure 2. Average world consumption and production growth rates, 1960 to 2010 ........................... 6

Figure 3. Global rice surplus (deficit) and ending stocks, 1960 to 2012 .......................................... 6

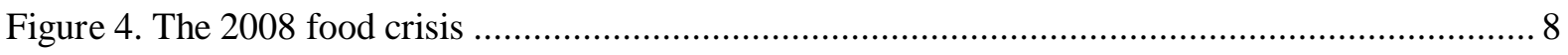

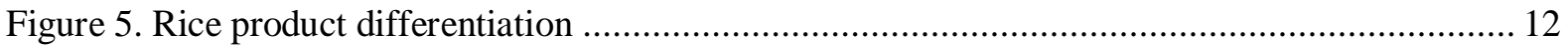

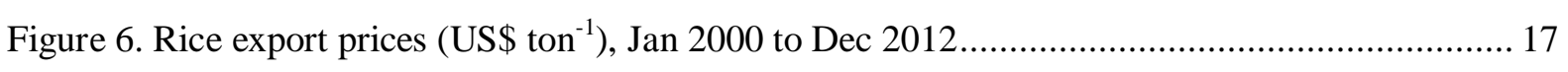

Figure 7. Prevalence of cointegration by geographical region....................................................... 23

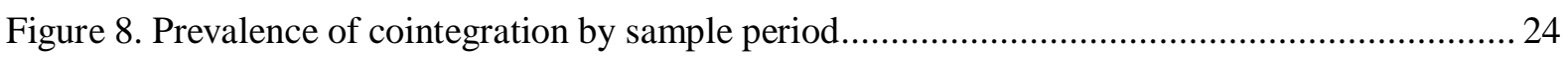

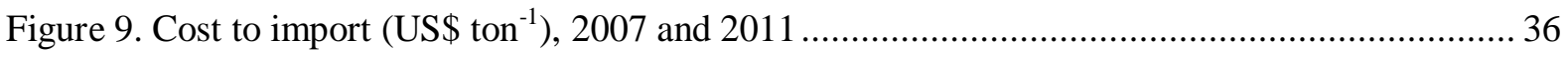



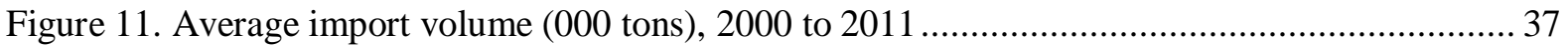

Figure 12. Share of rice in total caloric food consumption in the Philippines .................................. 40

Figure 13. Rice demand and supply in the Philippines, 1961 to 2012 ............................................ 41

Figure 14. Rice price trends in the Philippines, 1961 to 2012 ....................................................... 43

Figure 15. Thresholds and regime-switching, Philippines (national average, all sample).................. 47

Figure 16. Thresholds and regime-switching, Philippines (national average, sample-split) .............. 48

Figure 17. Price difference volatility (national average, sample-split) .............................................50

Figure 18. Domestic rice prices in the Philippines $\left(\mathrm{Php} \mathrm{kilo}^{-1}\right)$, Jan 2006 to Dec 2012 ..................... 50 


\section{List of annex}

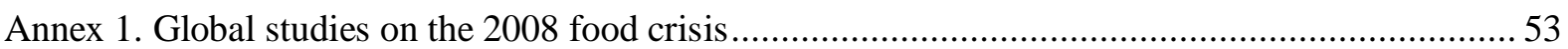

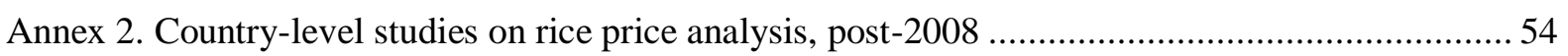

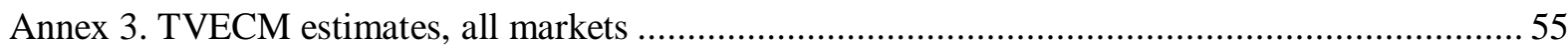

Annex 4. TVECM estimates using Vietnam 5\% as IRP, by country ............................................. 62 


\section{Introduction}

The increase in the price of rice from US\$322 ton ${ }^{-1}$ in 2007 to more than US\$1,000 ton ${ }^{-1}$ in April 2008 raised concerns among governments around the world. International organizations such as IFPRI, FAO, the World Bank, and IRRI came up with recommendations to address apprehensions about food security (FAO, 2008; IRRI, 2008; von Braun, 2008a; World Bank, 2008). The surge in rice prices generated renewed interest in the global rice economy. Because rice is the most important food crop of the developing world and the staple food of more than 3 billion people (IRRI, 2011), price transmission (PT) analysis of international rice markets helps better understand market integration, the dynamics of price relationships between the export and domestic markets, and the extent to which price shocks are transmitted to the poor.

This study provides empirical evidence of PT between the international and domestic markets of rice using price series from January 2000 to December 2012 and contributes to the literature in two aspects. First, we examine export prices that can serve as international reference price ${ }^{1}$ in PT analysis to determine the relevant world price for domestic rice markets. Second, we estimate thresholds and adjustment parameters using an improved estimation technique for threshold models to examine trade costs in spatial price relationships from world-to-domestic rice markets. We are not aware of publications in price transmission analysis which addresses these two points using a consistent set of price data for a large number of countries. We also characterize the dynamics of price relationships between world to domestic markets before and after the 2008 food crisis and across geographical regions.

The analysis of PT is important because prices drive decisions of economic agents in the allocation of resources and output mix and PT integrates markets vertically and horizontally (Meyer and von Cramon-Taubadel, 2004). Thus, studies on PT are usually empirical exercises that examine the predictions of economic theory and provide important insights as to how changes in one market are transmitted to another (Rapsomanikis et al., 2003). This reflects the extent to which markets function and, in turn, the extent of market integration. IFPRI (2011) lists at least three ways in which the results of PT analysis can help in the interpretation of price trends. First, it can help interpret changes in prices in a given market. If there is a relationship between international and domestic prices, the analysis can show how quickly domestic prices react to changes in world prices. However, if there is no relationship between the two prices, the explanations can focus on understanding domestic supply and demand, and thus avoid the erroneous attribution of change to world prices. Second, in the context of two prices, the analysis will help in looking at the direction of causation between markets. Third, PT analysis may help forecast prices in the short term. This prediction will be better if there is a strong relationship between local and world prices.

The paper is organized as follows: Section 2 describes trends in the rice economy and discusses some aspects of the 2008 food crisis. Sections 3 and 4 contain the two papers which discusses the price transmission mechanism in the international rice market. Section 5 highlights PT results for the Philippines, while Section 6 concludes and draws policy implications.

\footnotetext{
1 "World price", "export price", and the "international reference price" refer to same concepts in this study.
} 


\section{The rice economy}

\subsection{Trends in the international rice market}

Throughout history, wheat, maize and rice have been the most important grains for human consumption. Currently, over 500 million hectares are dedicated to cultivating these crops each year. Table 1 compares the three crops in terms of production, area, and exports over time. Rice is second to wheat in terms of harvested area and third in terms of total production. While export levels have increased from less than 10 million tons prior to 1980 , the world market for rice has historically been thin. In 2010, only about 31 million tons of rice was traded, compared with more than 134 million tons of wheat and 93 million tons of maize. Unlike wheat and maize, which are also processed as animal feed and as feed stocks for biofuel and sweetener production, rice is predominantly used for human consumption.

Table 2 shows that over 80 percent of the world's rice is produced and consumed in Asia. Rice is central to the region's culture, and in many regions of Asia, the word 'rice' is synonymous with 'food' (Asia Society and IRRI, 2010). The geographic concentration of rice production and the dominance of rice in domestic diets have compelled most Asian countries to protect producers and consumers from fluctuating world prices in order to achieve food security (Timmer and Dawe 2007). Indeed, world rice prices have historically been more volatile than the prices of other grains (figure 1). Jayne (1993) discusses several factors that contribute to the instability of world rice markets: the geographic concentration of rice production which increases exposure to systematic production shocks due to weather, a thin and fragmented world market with high costs in trading, low domestic price elasticities of demand, and relatively low world stockholdings.

Figure 2 presents trends in global rice production and consumption. It conveys three important developments that transpired in the last 50 years. First is the decline of both consumption and growth rates of rice. Second is the two major rice price peaks (1975 and 2008) that occurred in periods in which the growth of consumption outpaced production. Third is our justified concern that current rates of consumption have consistently outpaced production in the last two decades.

Figure 3 highlights years in which production exceeded consumption, which can also be considered as the surplus years. The surplus years gave momentum to build up level of stocks, reaching as high as 146 million tons of rice in 2000 or $37 \%$ of world production. This gave rise to complacency in many Asian countries as the world price of rice dipped below US\$200 ton ${ }^{-1}$. There was overproduction and it appeared to made sense at that time to reduce large stockholdings in order to reduce storage opportunity costs. However, the story quickly changed. A series of deficit years brought down stocks to levels seen in the 1980s and world rice prices gradually increased. Nevertheless, the 2008 food crisis was not a direct cause of adverse production shocks. While average consumption growth rates have surpassed production, there is no current shortage of rice in the world.

\subsection{The 2008 food crisis}

There has been a significant amount of analyses of rice markets that coincided with the spike in rice prices in 2008. Many international developmental organizations released their own policy recommendations and initiatives designed to ease the impact of price shocks. 
Understandably, rice provides the basic food and, thus, the object of considerable policy focus for Asian governments (Dawe 2010). Due to fear of spiraling commodity prices, several major exporting countries adopted export restrictions to insulate its domestic markets. For some developing countries that rely on food imports, the price shock threatened food security. Many factors that have led to the 2008 food crisis, include the: (1) growing world demand for basic food commodities, (2) demand of cereals for biofuel, (3) rise in petroleum prices, (4) slowing rate of increases in farm cereals for biofuel, (5) evolution of global food commodity stocks, (6) commodity speculation, and (7) macroeconomic factors. ${ }^{2}$

Dawe (2010) provides a comprehensive analysis of the 2008 rice crisis. It is important to note two things. First, the recent peak in rice prices was much less than the peak reached during the 1972-73 crisis. Second, rice prices had gradually increased in real terms five years prior to the crisis. There was a decline in global wheat production in 2007 and wheat prices started rising in May 2007. This was followed by an increase in corn prices as demand for ethanol production in the U.S. put pressure on available supplies. However, the actual panic that resulted in the world rice market was not supported by fundamentals of supply and demand. The drastic surge in rice prices was not caused by adverse shocks to rice production or low stocks. Nonetheless, there are elements related to supply and demand that contributed to the atmosphere of concern to the world grain market such as, rising oil prices, weak US dollar, biofuel mandates, and weather-induced decline in wheat production. These factors arguably contributed to the policy decisions by major rice trading countries that triggered rice prices to skyrocket in the world market.

It is important to trace the events and government policy decisions to be able to understand what happened to the world rice market. Slayton (2009) provides a detailed chronology of events that transpired during the 2008 rice crisis (figure 4).

Four countries played pivotal roles in the global rice crisis that ensued: Thailand, Vietnam, India, and the Philippines. Thailand, Vietnam, and India are the top three rice exporters in the world, controlling more than $50 \%$ of global rice trade, or 17.6 million tons annually from 2004 to 2008. Prior to the crisis, Philippines had been importing over 1 million ton of rice on average since 2004.

On 9 October 2007, India banned exports of non-Basmati rice. This was replaced three weeks later with a series of minimum export prices set above world price levels. This restriction had its roots in a weather-induced production shortfall of wheat crop in 2006, resulting to high wheat imports. India stabilized national cereal prices by bartering rice for wheat, thereby reducing wheat imports and rice exports.

On 21 July 2007, Vietnam reached its export sales quota and no further supplements were issued. However, this ban was anticipated and did not substantially disrupt international rice trade or create uncertainty. The situation was different in 2008. Export sales were allowed in January 2008 but only for two and a half weeks before the government banned sales due to fears triggered by cold weather in Red River Delta. This created the first uncertainty because the duration of the restriction was not clear.

\footnotetext{
${ }^{2}$ Refer to annexes 1 and 2 for a list of publications on the 2008 food crisis.
} 
Table 1. Global average production, area, and exports of grains, 1960 to 2010

\begin{tabular}{cccc}
\hline Milled production (1000 mt) & Maize & Rice & Wheat \\
1960-1970 & 230,734 & 173,967 & 267,528 \\
1970-1980 & 338,681 & 233,758 & 371,075 \\
$\mathbf{1 9 8 0 - 1 9 9 0}$ & 436,456 & 308,297 & 489,283 \\
$\mathbf{1 9 9 0 - 2 0 0 0}$ & 544,347 & 371,923 & 568,290 \\
2000-2010 & 696,063 & 412,996 & 611,148 \\
\hline Area harvested (1000 ha) & & & \\
1960-1970 & 106,355 & 123,888 & 212,479 \\
1970-1980 & 120,282 & 138,531 & 220,997 \\
1980-1990 & 128,128 & 144,335 & 229,778 \\
1990-2000 & 135,219 & 149,284 & 223,317 \\
2000-2010 & 147,329 & 152,952 & 217,924 \\
\hline 1960-1970 & & & \\
1970-1980 & $10.1 \%$ & $4.3 \%$ & $19.8 \%$ \\
1980-1990 & $14.7 \%$ & $3.9 \%$ & $17.9 \%$ \\
1990-2000 & $14.9 \%$ & $3.9 \%$ & $20.4 \%$ \\
2000-2010 & $12.0 \%$ & $5.1 \%$ & $18.5 \%$ \\
\hline
\end{tabular}

Note: Average values in each period using annual data from USDA PS\&D.

Table 2. Top 10 rice producers and consumers, values in decreasing order, 2012

\begin{tabular}{lrrlrr}
\hline Country & $\begin{array}{c}\text { Production } \\
\text { (000 mt) }\end{array}$ & $\begin{array}{c}\text { \% of } \\
\text { World }\end{array}$ & Country & $\begin{array}{c}\text { Consumption } \\
\text { (000 mt) }\end{array}$ & $\begin{array}{c}\text { \% of } \\
\text { World }\end{array}$ \\
\hline China & 143000 & $30.3 \%$ & China & 144000 & $30.9 \%$ \\
India & 105240 & $22.3 \%$ & India & 94031 & $20.2 \%$ \\
Indonesia & 36550 & $7.8 \%$ & Indonesia & 38127 & $8.2 \%$ \\
Bangladesh & 33820 & $7.2 \%$ & Bangladesh & 34500 & $7.4 \%$ \\
Vietnam & 27519 & $5.8 \%$ & Vietnam & 21900 & $4.7 \%$ \\
Thailand & 20200 & $4.3 \%$ & Philippines & 12850 & $2.8 \%$ \\
Burma & 11715 & $2.5 \%$ & Thailand & 10600 & $2.3 \%$ \\
Philippines & 11428 & $2.4 \%$ & Burma & 10400 & $2.2 \%$ \\
Brazil & 7990 & $1.7 \%$ & Japan & 8250 & $1.8 \%$ \\
Japan & 7756 & $1.6 \%$ & Brazil & 7850 & $1.7 \%$ \\
Others & 66048 & $14.0 \%$ & Others & 82950 & $17.8 \%$ \\
\hline Source
\end{tabular}


Figure 1. Annual grain prices, 1960 to 2012

(a) Nominal prices



(b) Real prices

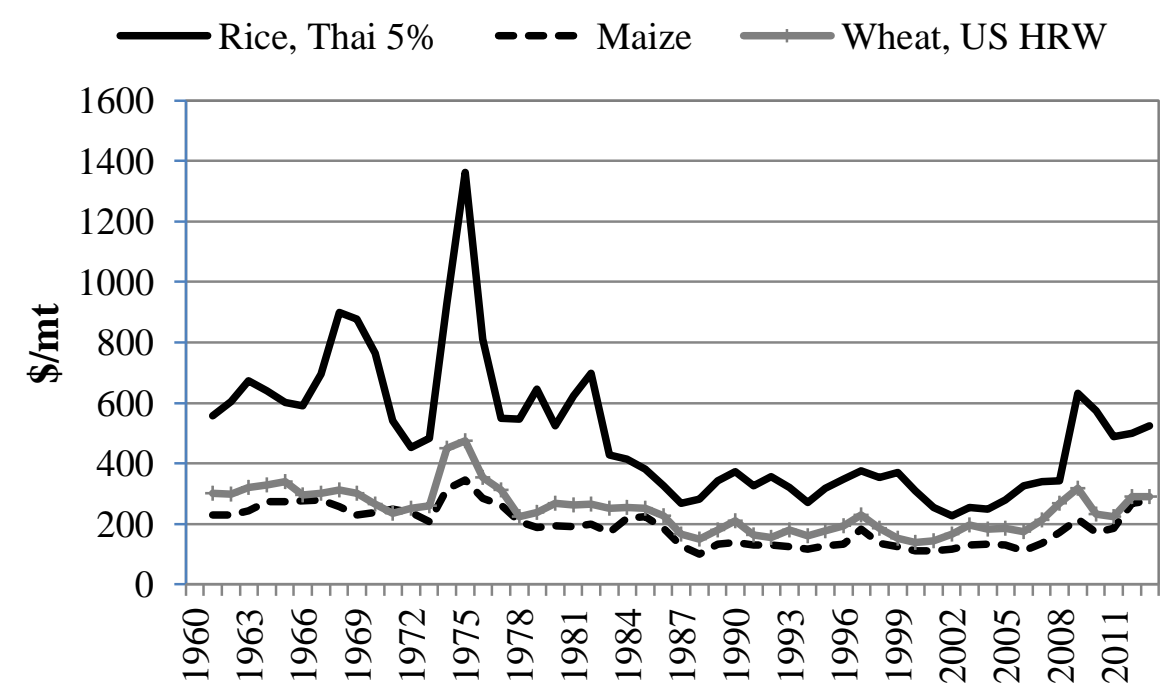

Source: WB Pink Sheet. 
Figure 2. Average world consumption and production growth rates, 1960 to 2010

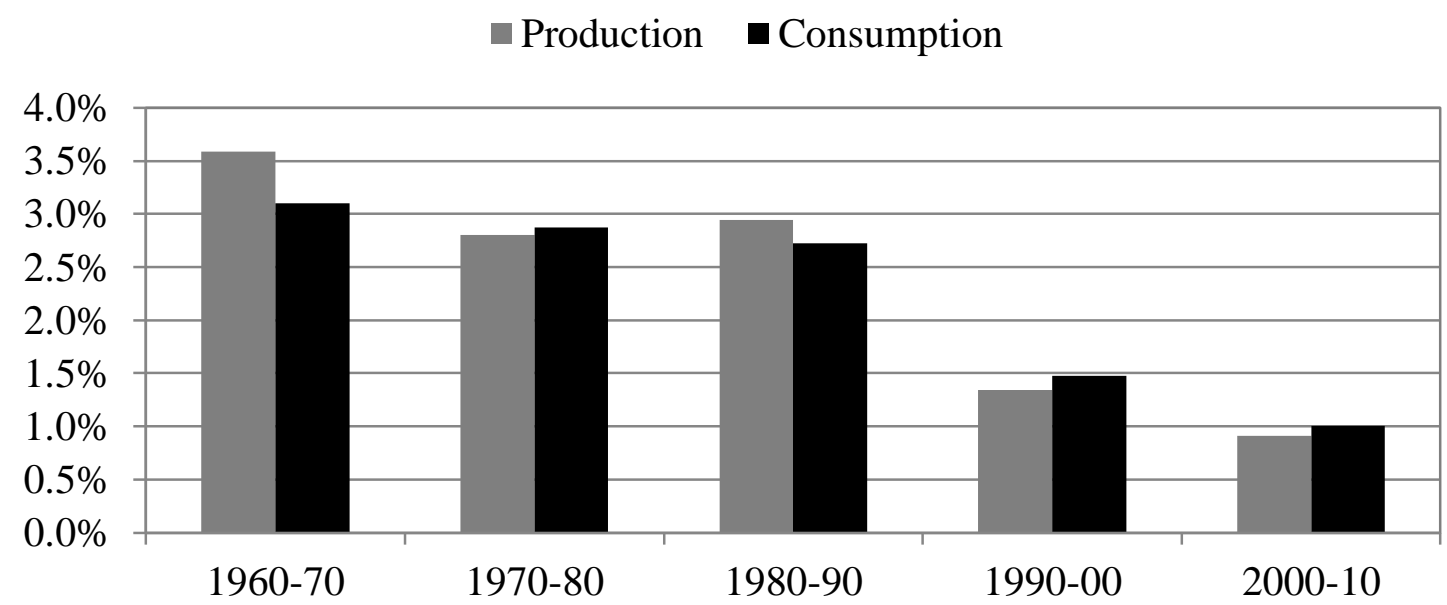

Source of raw data: USDA PS\&D.

Figure 3. Global rice surplus (deficit) and ending stocks, 1960 to 2012

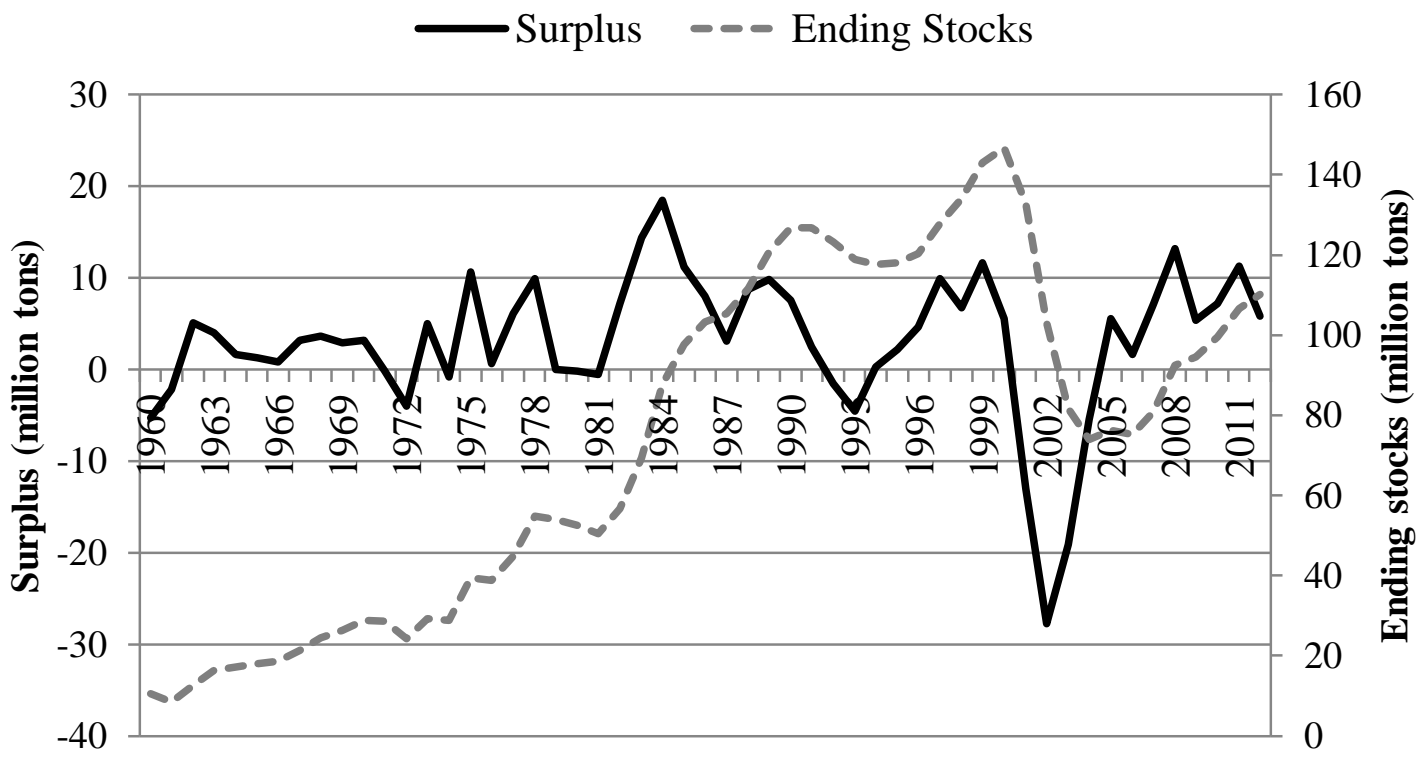

Source of raw data: USDA PS\&D. 
The Philippines issued rice tenders in December 2007 and January 2008 for imported rice. Vietnam, through Vinafood 2, participated in the negotiations and this resulted in contracts for over 700,000 tons, in which the bulk was scheduled for first quarter arrival in Philippines. The price paid in the January 2008 tender was about US\$70 ton $^{-1}$ higher than the December 2007 tender and only 320,000 tons were actually delivered.

While there are no signs of crisis in the Philippines, the government continued to put out more large tenders to build up domestic stocks. On 11 March 2008, the Philippines agreed to pay the increasingly high prices quoted by Vietnam, even though they were US $\$ 150$ above the spot market levels.

On 1 April 2008, India banned all rice exports. This was the second source of uncertainty because it was not clear how long the ban would last. It is important to note that trade did not completely stop, as over 2.5 million tons of non-Basmati were exported to Bangladesh, Bhutan, Sri Lanka, and other countries from October 2007 to March 2008.

The Indian export ban perhaps triggered the Philippines to announce another tender in early May, nine days before the 17 April 2008 tender. The peak in rice prices was reached during the April tender, when the Philippines bought 364,000 tons at an average price of US $\$ 1,100$ ton $^{-1}$ from the export market. During this period, the Philippines pursued an agreement with Thailand for more rice deliveries and made repeated efforts to commercially tender for U.S. rice. Arguably, these tenders fuelled speculation and led to higher prices in the global rice market as it conveyed the impression that the Philippines, the top importer of rice, was willing to pay almost any price for rice imports.

Thailand followed these events but did not impose any export restrictions. From October 2007 to September 2008, it exported 11.7 million tons of rice. However, policies and statements of the Thai government contributed to the uncertainty in the world market and created concerns that Thailand would restrict exports. In 18 March 2008, the Deputy Commerce Minister was quoted saying the government was studying measures to ensure that there would be sufficient rice to meet domestic demand (Bangkok Post, 2008). In late April 2008, the government publicized a proposal for establishing a rice exporter cartel with Vietnam, Cambodia, and Myanmar. This was quickly dumped on 6 May 2008 because of the strong negative global public opinion that resulted. 
Figure 4. The 2008 food crisis

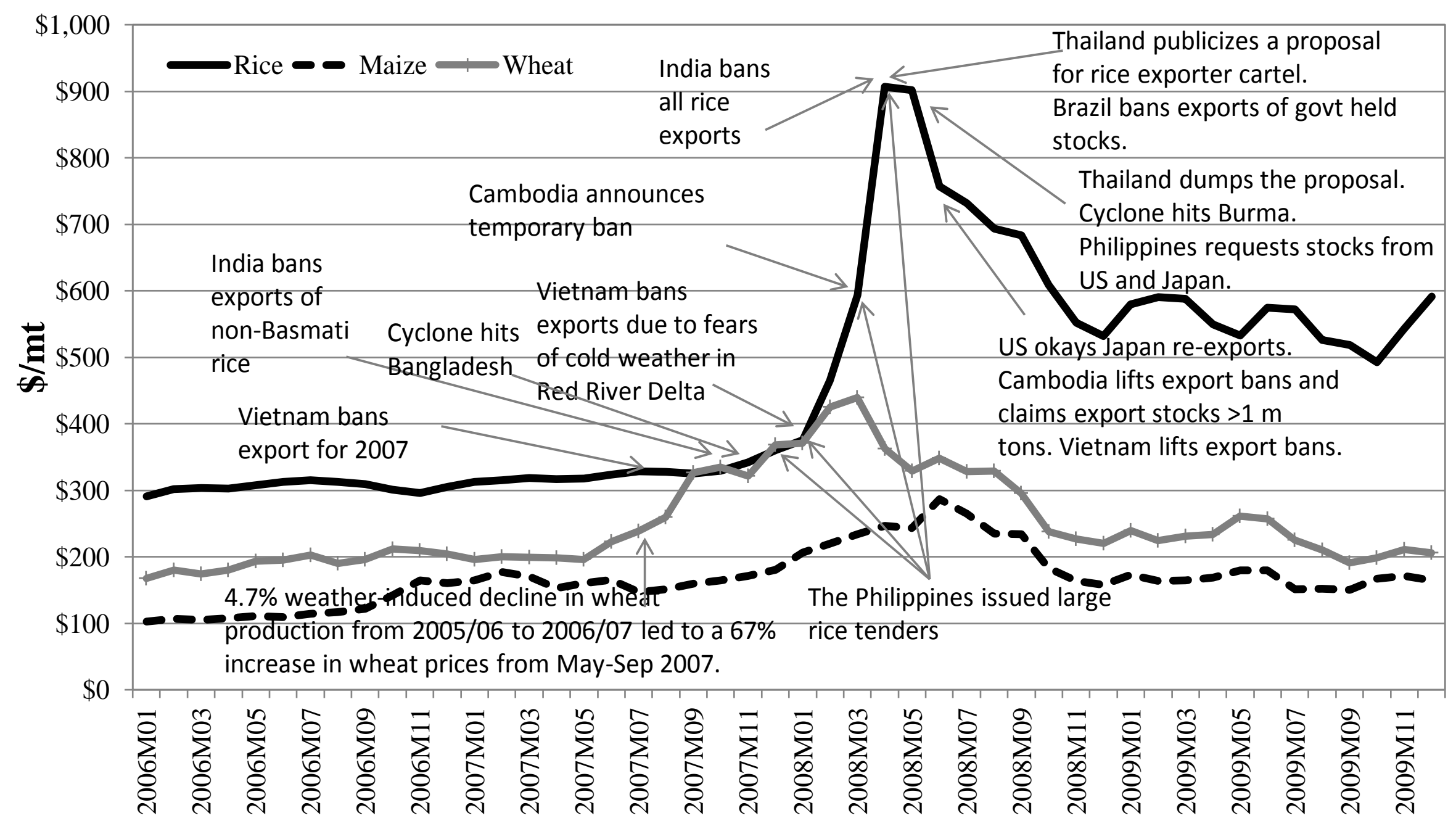


Other countries contributed to the atmosphere of uncertainty by releasing statements of intent on export restrictions and aggressive stockpiling to secure domestic rice supply. ${ }^{3}$ The media also played a significant role in magnifying speculations from export restrictions. Statements by key officials of well-known international organizations forecasting higher prices further contributed to market fears. ${ }^{4}$ Needless to say, many of the proposals failed to materialize after the world rice prices reversed direction.

The upward momentum of rice prices overturned in May 2008. The Philippines disclosed in 19 May 2008 that Japan might provide 200,000 tons of imported rice. This came after a paper released by the Center of Global Development on 9 May suggesting that Japan, Thailand, China, and the U.S. could solve the rice crisis (Slayton and Timmer, 2008). Pakistan affirmed it had an additional one million tons available for export. Ten days after, Thailand reported that it is prepared to sell its stocks to the Philippines at friendship prices. Cambodia also lifted its remaining export restrictions on 26 May 2008. The Philippines also concluded a government-to-government deal with Vietnam for 600,000 tons in mid-June, and signaled that it had met its import demands for the year. A few days later, Vietnam lifted its export ban. Many events have led to the reversal of rice prices but the mere prospect of additional rice being released onto the world market seemed to have been adequate to quash the mounting trend of prices. By the end of 2008, rice prices have declined by 41 percent from its peak in April of that year. However, the declining trend does not indicate any reversal of the price levels seen before the food crisis. Rice prices have stabilized at around US $\$ 500$ ton $^{-1}$ in the last three years, much higher than the US\$200 ton ${ }^{-1}$ from 2000 to 2004 levels.

\footnotetext{
${ }^{3}$ Malaysia announced plans in mid-January 2008 to increase Bernas' stock levels from 92,000 tons to 550,000 tons. Nigeria announced plans to increase imports by extra 500,000 tons and build up reserve by end of 2008 . Egypt suspended exports several times in 2008 -- January to February 2008, March to October 2008, and then extended to April 2009. China delayed issuance of export quotas during the crisis. Cambodia, a minor exporter averaging 330,000 tons from 2004-05 to 2006-07, temporarily banned exports in late March 2008. This ban was soon largely lifted, within two weeks of original announcement, and was not as strict or effective. Brazil, also a minor exporter averaging over 250,000 tons, banned all rice exports. A few days later, it was clarified that this only involved government held stocks.

4 "The rise in prices of food commodities all over the world is not going to ease in the short term..." FAO's DG Jacques Diouf (Press Trust Of India, 2008). "Although the credit crunch has lowered the price of food... the stage is set for the next food crisis" IFPRI DG Joachim von Braun (von Braun, 2008b). "At the moment, high and unstable food prices look like they are here to stay for some time - perhaps years" (von Braun, 2008a). "The recent surge in world food prices is already creating havoc... worse is yet to come" (Sachs, 2008). "The trend in high food prices will likely persist over the next few years, if not longer. The era of cheap food... may thus be over" (ADB, 2008). "The observed increase in food prices is not a temporary phenomenon, but likely to persist in the medium term" (World Bank, 2008). "We believe that higher food prices are going to stay at least for another 2 years before they began to decline, but they will remain at elevated levels till well about say 2015." Vikram Nehru, Chief Economist for WB's East Asia and Pacific Region (Australian Broadcasting Corporation, 2008). "Food prices will remain high over the next decade even if they fall from current records, meaning millions more risk further hardship or hunger..." OECD and FAO (Love, 2008).
} 


\section{The world rice price ${ }^{5}$}

\subsection{Introduction}

Price transmission (PT) and market integration methods are often used to provide insights into how changes in world markets are transmitted to domestic markets (e.g. Baquedano and Liefert, 2014). Such analysis requires a consensus on an appropriate international reference price (IRP). For some internationally traded products, such a consensus prevails. In studies of wheat market integration for example, US Hard Red Winter FOB Gulf is very commonly used as the IRP; in the case of (yellow) maize, the dominant IRP is US No 2 Yellow FOB Gulf. The same cannot be said for rice, perhaps because there is no market-determined average world price for rice at any given point in time (Barker et al., 1985). This observation has important policy implications because it suggests that PT analysis can be misleading if domestic rice markets are not matched up with the appropriate IRPs. Moreover, it implies that the failure to find integration between world and domestic rice markets can be a result of failure to define the appropriate IRP. For example, using monthly export prices for Thai 100\%B and Thai A1 Super from 1990 to 1999, Sharma (2003) finds cointegrating relations for South Korea, Pakistan, and Thailand, but not for Indonesia, Philippines, and Sri Lanka. Minot (2011) examines the relationship between world prices and domestic prices in African countries using Thai A1 Super as the IRP and finds that only 8 of $17(47 \%)$ domestic rice price series are cointegrated with it.

The large range of different rice types and quality distinctions have resulted in less unanimity on the IRP for rice than there is for wheat and maize. There are four major sources of historical rice export prices. ${ }^{6}$ The longest monthly price series is Thai $5 \%$ which started in 1960 and is maintained by the World Bank. The FAO offers weekly data for Thai $100 \% \mathrm{~B}$ and Thai A1 Super. Vietnam export prices prior to 2000 are not easy accessible. Hence, Thailand rice, Thai $5 \%$ and Thai $100 \%$ B, are often used in PT studies. Falcon and Monke (1980) made the first explicit statement that Thai $5 \%$ brokens can serve as a reasonable indicator of movements on global rice markets since it is a widely traded variety. Nielsen \& Yu (2002) suggest that the international rice market is highly segmented and dominated by Thailand. In 2007, Calpe confirms that the most frequently used export price is Thai 5\% brokens, which has been quoted since 1957. However, several other prices are commonly used as IRPs as well. For example, the Food Security Portal of the International Food Policy Research Institute (IFPRI) makes reference to FAO's international commodity prices database, which lists Thai 100\%B and Thai A1 Super as world market prices for rice (IFPRI, 2013). ${ }^{7}$ Some price transmission studies on world markets do not explicitly state which IRP has been used (Baquedano and Liefert, 2014; Cudjoe et al., 2010; Imai et al., 2008).

This study aims to improve our understanding of price relationships in the world market for rice. In this context, we examine the cointegration of individual domestic prices with a number of possible IRPs extracted from the FAO Global Information and Early Warning System (GIEWS) food price database. While a few studies account for the differences in

\footnotetext{
${ }^{5}$ This chapter is co-authored with Stephan von Cramon-Taubadel. It has appeared as a GlobalFood Discussion Paper No. 17 (December 2012) and has been submitted to the Applied Economic Perspectives \& Policy (AEPP) journal. It received a "revise and resubmit" notice from AEPP as of August 2014.

${ }^{6}$ World Bank, Commodity Price Data (a.k.a. Pink Sheet) for Thai A1 Super, Thai 5\%, Thai 25\%, Viet 5\%; IMF, Primary Commodity Prices for Thai 5\%; FAO, International commodity prices for Thai A1 Super and Thai $100 \%$ B; FAO-GIEWS, Food Price Data for IRPs included in this study.

${ }^{7}$ Types and quality differences in export prices are discussed in the next section.
} 
types of rice available in the world market, ${ }^{8}$ most analyses have largely ignored this heterogeneity. However, PT studies that assume product homogeneity lead to "estimates with no clear interpretation of market integration" (Ghoshray, 2006). The growing literature using time series method to analyze commodity price relationships has been applied in hog markets by Faminow and Benson (1990), in cattle markets by Goodwin and Schroeder (1991), in seafood markets by Asche et al. (1997, 1999, \& 2004), and in grain markets by Ghoshray (2006) and Baquedano \& Liefert (2014). To our knowledge, no empirical analysis has been carried out to compare different potential IRPs for rice with a consistent set of price data for a large number of countries using a uniform methodology. Moreover, our sample period allows us to examine the dynamics of PT in the pre- and post-2008 food crisis regimes. While we anticipate that the results will confirm that international rice markets are heterogeneous, we expect to find that certain export prices do act as IRPs for certain markets segments and importing regions of the world.

The next section describes the types of rice traded in the global market. In the subsequent sections, we present the methods, data, and empirical results. The latter include: (1) a cointegration analysis from world to domestic rice markets and (2) an analysis of market integration between export types for rice. All of these analyses are based on the period January 2000 through December 2012. The final section presents conclusions that are relevant for the empirical analysis of the world rice market.

\subsection{Types of rice}

A wide range of rice types are sold on international markets (Barker et al., 1985) (figure 5). ${ }^{9}$ The bulk of the rice traded is long grain, usually from indica varieties, which is popular throughout South and Southeast Asia. There is a smaller market for short-grain, japonica varieties grown widely in East Asia and in other temperate zones of the world. Japonica rice is relatively sticky when cooked and has a shorter, thicker grain while indica is less sticky and becomes elongated when cooked. Other rice types (e.g., aromatic, glutinous) tend to be confined to particular regions and are generally traded as specialty items. Aromatic rice, mainly jasmine from Thailand and basmati from India and Pakistan, and glutinous rice, grown mostly in Southeast Asia and used in desserts and ceremonial dishes, typically sell at a premium in world markets.

Moreover, there are four forms of traded rice: rough, parboiled, brown, and milled (Childs and Burdett, 2000; Childs and Livezey, 2006; Knowledge Bank, IRRI, 2006; Texas A\&M University, 2011; USDA Agricultural Research Service, 2012). Rice that has been harvested from the plant with its husk intact is known as 'rough' or 'paddy' rice. When the husk is removed from rough rice, it is called 'brown' rice. Rice that has had its husk and bran layers removed by milling is called 'milled' rice. Milling rice increases its shelf life and provides consumers with a desired physical property - whiteness (Texas A\&M University, 2011). Rough rice can also be parboiled prior to milling, a process of soaking the rice in water and steaming it under intense pressure, which pushes nutrients from the bran layer into the kernel and makes the grain less likely to break during milling.

\footnotetext{
${ }^{8}$ Ghoshray (2008) and Nielsen and Yu (2002) examined cointegration among export rice prices by quality.

${ }^{9}$ We describe the types of rice in this section. A more detailed description can be found in Knowledge Bank, IRRI (2006) and USDA Agricultural Research Service (2012).
} 
Figure 5. Rice product differentiation
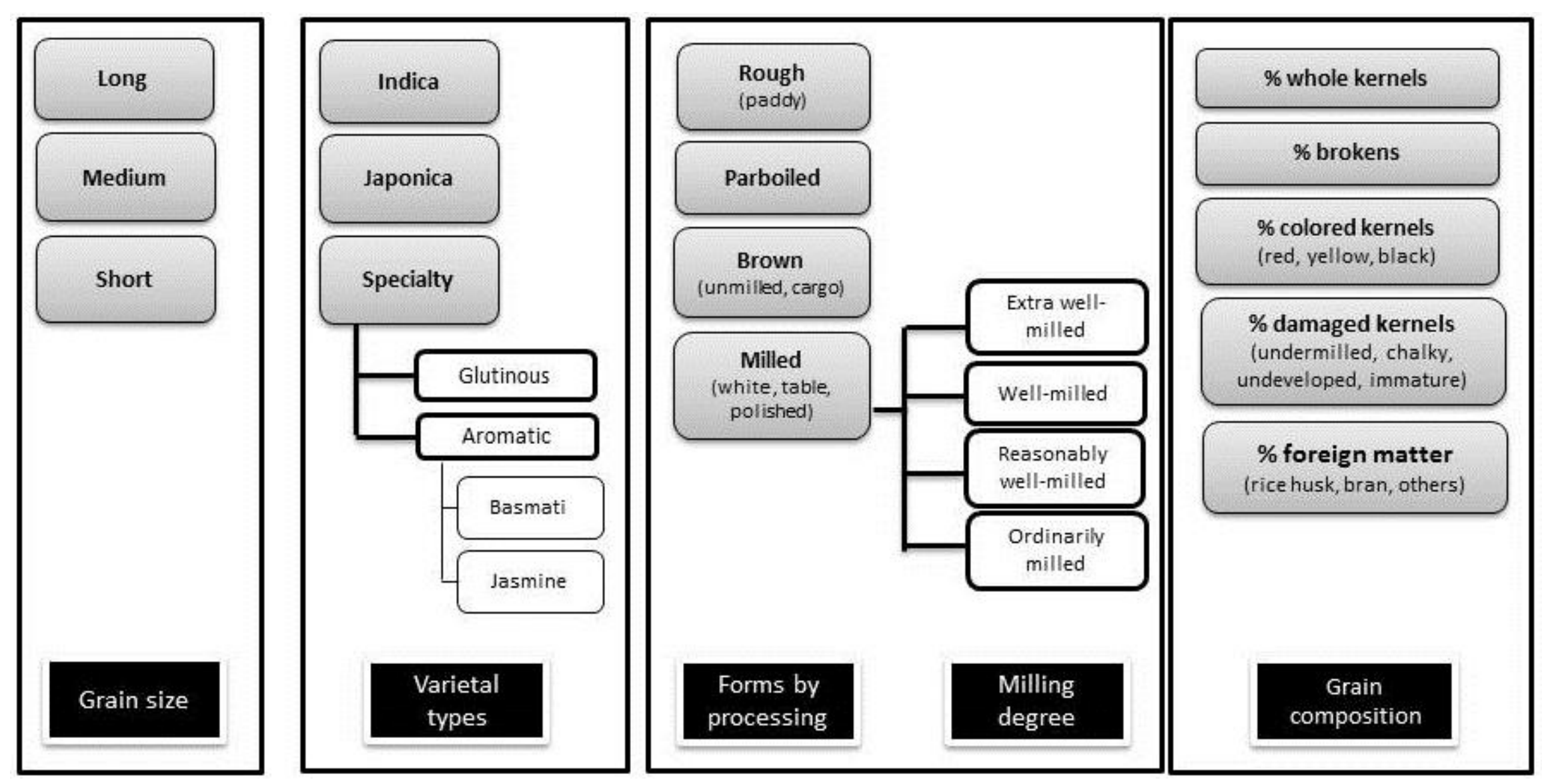
Rice entering the world market is further graded according to its milling degree and grain composition. However, there is a lack of international grading standards to measure and standardize variety and quality differences (McKenzie, 2012). For example, Thailand has 13 grades for milled white rice, ranging from 'Thailand $100 \%$ Grade A', with brokens not exceeding 4\%, to 'Thailand A1 Special', with $100 \%$ brokens obtained from the milling of 15\% and 25\% Super (Thailand Ministry of Commerce, 1997). The U.S. has 6 grades for milled rice, ranging from 'US No. 1' with brokens not exceeding 4\%, to 'US No. 6' with brokens not exceeding 50\% (USDA Department of Agriculture, 2009). Vietnam has 7 major grades based on maximum broken limits.

Manful (2010) lists several characteristics of a good quality rice grain but notes that grain quality has different meanings at different levels of the rice value chain. A good quality rice has little or no chalk, translucent appearance, uniform coloration (white for milled rice and yellowish for parboiled rice), and a high percentage of whole unbroken grains. The percentage of whole unbroken grains is perceived by consumers as the most important quality, unlike other cereals, because rice is eaten as a whole grain. Multi-country comparative research on rice grain quality in Asia confirms that quality preferences vary across countries and regions, but in general, consumers prefer higher head rice yield, more translucent grain and a high percentage of whole kernels (Juliano, 1993; Knowledge Bank, IRRI, 2006; Unnevehr et al., 1992; Unnevehr, 1986). ${ }^{10}$ However, given the many dimensions of rice quality there are no strict lines that divide different qualities on a monotonic scale from 'very low' to 'very high'.

Calpe (2004) reports that indica varieties represent $75 \%$ of world trade, while japonica and basmati rice account for $24 \%$. Most exported rice is milled $(77 \%)$, and about $15 \%$ is parboiled. Milled rice with less than $20 \%$ brokens accounts for $75 \%$ of global trade. In short, world rice trade is dominated by high-quality, milled indica varieties. Five countries account for roughly three-fourths of global rice trade. Thailand supplies about $30 \%$ of global rice exports and has been a consistent big exporter, particularly of high quality indica and aromatic Jasmine. Vietnam specializes in the export of lower quality indica. The U.S. produces and exports all types and forms of rice, and India and Pakistan are major exporters of aromatic Basmati rice.

\subsection{Methods and data}

The empirical tool that we use to examine evidence of PT is cointegration analysis and, in particular, the vector error correction model (VECM). The VECM is a re-parameterization of the standard vector autoregressive (VAR) model which relates the current levels of a set of time series to lagged values of those series. The VECM takes the following general form:

\footnotetext{
${ }^{10} \mathrm{Head}$ rice yield is the weight of whole rice grain remaining after milling, as a percentage of the total weight of the paddy. Breakage of grain during milling reduces the percentage of whole grain. The whiteness of rice ranges from white to yellow. Yellowness occurs because of aging or higher protein content. Translucence relates to the degree of crystallinity of the starch. Chalky grains are softer than translucent grains and are more likely to break during milling (Knowledge Bank, IRRI, 2006).
} 


$$
\Delta \mathrm{P}_{\mathrm{t}}=\Pi \mathrm{P}_{\mathrm{t}-1}+\sum_{\mathrm{k}=1}^{\mathrm{q}} \Gamma_{\mathrm{k}} \mathrm{P}_{\mathrm{t}-\mathrm{k}}+\varepsilon_{\mathrm{t}}
$$

where

$\mathrm{P}_{\mathrm{t}}$ is an $n \times 1$ vector of $n$ price variables;

$\Delta$ is the first difference operator;

$\Pi$ is an $n \times n$ matrix of estimated parameters that describe the long-term relationship and the error correction adjustment;

$\Gamma_{\mathrm{k}}$ is a set of $n \times n$ matrices of estimated parameters that describe the short-run relationship between prices, one for each of $q$ lags included in the model; and

$\varepsilon_{\mathrm{t}}$ is an $n \times 1$ vector of error terms.

The key parameter in the VECM is the $\Pi=\alpha \beta^{\prime}$ which contains the long-term relationship, or the cointegrating vector $(\beta)$, and the adjustment parameters $(\alpha)$ which reflects the speed of adjustment. $\mathrm{Pi}(\Pi)$ can decomposed into $\beta$ and $\alpha$ if the reduced rank (r) of $\Pi$ is $0<r<n$, where $n$ is the number of variables. The rank of $\Pi$ determines the number of stationary linear combinations of the variables in $\mathrm{P}_{t}$, and is usually estimated using a Johansen trace test (Johansen 1991). If the rank is exactly $n-1$, all of the prices follow the same stochastic trend (Stock and Watson, 1988) and correspondingly all of the underlying markets are integrated. The test allows for more than one cointegrating relationship, so it is also applicable to multivariate settings, $n>2$.

In the first stage of our study, we use a bivariate version of the VECM in equation (1) $(n=2)$ to analyze international to domestic rice PT between 269 local markets in 58 Asian, African, and Latin American countries and each of the 14 export prices in the FAO-GIEWS database as a potential IRP. Gregory-Hansen (1996) tests for cointegration with a structural break indicate regime shifts in many of the domestic-IRP price cointegration relationships towards the end of 2007. Thus, we employ a modification of equation (1) which allows for a structural break in December 2007. This date roughly corresponds to the beginning of increased volatility in export prices of rice.

The insights generated by the analysis of IRP to domestic rice PT form the basis for the second stage of our study, which is an analysis of integration within the export market for rice. We begin by examining the relationships between all pairs of the 14 export prices in the FAO-GIEWS database. We test whether the potential IRPs share the same long-run stochastic trend. If they do, then the prices are cointegrated and they are expected to move together over time through arbitrage, substitution, or both (Ghoshray, 2008). If this were the case, it would not matter whether we use, for example, Vietnam $25 \%$, Vietnam $5 \%$, or Thai $100 \% \mathrm{~B}$ when studying PT on world rice markets. Once cointegrated export price pairs are identified, we proceed by testing the addition of further export price series into quality clusters using the Johansen procedure for multivariate cointegration tests. We define our clusters using the percentage of brokens, i.e. rice type with less than $20 \%$ brokens is considered high quality. Asche et al. (1999) have shown that multivariate cointegration analysis can be implemented to test the law of one price (LOP) in groups of prices. The LOP holds for a group of $n$ prices when they move proportionally to each other in the long run. If the multivariate cointegration test indicates the existence one common trend in a group of $n$ prices, i.e. the rank of $\Pi$ is exactly $n-1$, the rice export types in that group are cointegrated and the LOP holds in that group (Asche et al. 1997). Otherwise, the rice types are segmented 
and are not close substitutes. In this way, we can identify IRPs for individual segments of the export rice market.

We apply the steps outlined above to 14 IRP (table 3) and 269 domestic rice prices extracted from the FAO-GIEWS food price database (table 4). These monthly data cover January 2000 to December $2012(T=156)$. The FAO-GIEWS database was established in 2009 as part of the FAO Initiative on Soaring Food Prices and now serves as the most important global source of updated price information. The export prices reported in FAOGIEWS are average FOB port quotations in US dollars collected from national official sources. Together, they represent about 11 million tons of rice or one-third of annual global rice trade. Figure 6 presents graphs of these 14 prices and their first differences. We examine the time series properties of the data using the Augmented Dickey-Fuller (ADF) tests for each of the price series expressed in log levels and in log differenced form. The tests confirm the presence of unit roots in levels and stationarity in first differences.

Table 3. Descriptive statistics for potential IRPs

\begin{tabular}{|c|c|c|c|c|c|c|c|}
\hline \multirow[t]{2}{*}{ Variety $^{1}$} & \multirow{2}{*}{$\begin{array}{c}\text { Description } \\
\text { (origin/type) }\end{array}$} & \multirow{2}{*}{ Quality $^{2}$} & \multirow{2}{*}{$\begin{array}{c}\text { Average } \\
\text { price }^{3}\end{array}$} & \multirow{2}{*}{$\begin{array}{l}\text { Std } \\
\text { dev }\end{array}$} & \multicolumn{3}{|c|}{ Optimal ADF trace statistics } \\
\hline & & & & & $\operatorname{lag}^{4}$ & level & diff \\
\hline $\mathrm{I} 25$ & India $-25 \%$ broken & Low & 281 & 97 & 4 & 0.655 & $-4.332 *$ \\
\hline $\mathrm{P} 25$ & Pakistan $-25 \%$ broken & Low & 283 & 119 & 3 & 0.750 & $-5.507^{*}$ \\
\hline $\mathrm{T} 25$ & Thailand $-25 \%$ broken & Low & 331 & 163 & 2 & 0.953 & $-6.207 *$ \\
\hline $\mathrm{TS}$ & Thailand - A1 Super & Low & 286 & 147 & 3 & 1.052 & $-5.685^{*}$ \\
\hline V25 & Vietnam - $25 \%$ broken & Low & 294 & 139 & 2 & 0.420 & $-6.309^{*}$ \\
\hline $\mathrm{T} 100$ & Thailand - Thai $100 \% \mathrm{~B}$ & High & 378 & 185 & 2 & 0.842 & $-6.131^{*}$ \\
\hline T5 & Thailand - $5 \%$ broken & High & 366 & 180 & 2 & 0.792 & $-6.119 *$ \\
\hline $\mathrm{TP}$ & Thailand - Parboiled 100\% & High & 384 & 193 & 3 & 0.729 & $-5.915^{*}$ \\
\hline UL & USA - Long Grain 2/4\% & High & 425 & 167 & 2 & 0.580 & $-5.812^{*}$ \\
\hline V5 & Vietnam - $5 \%$ broken & High & 321 & 151 & 3 & 0.545 & $-6.691^{*}$ \\
\hline PB & Pakistan - Basmati Ordinary & Premium & 671 & 302 & 2 & 1.205 & $-7.093^{*}$ \\
\hline $\mathrm{TF}$ & Thailand - Fragrant & Premium & 645 & 307 & 2 & 0.830 & $-5.986^{*}$ \\
\hline TG & Thailand -Glutinous & Premium & 521 & 253 & 3 & 1.006 & $-6.072 *$ \\
\hline UM & USA - California Medium Grain & Premium & 536 & 299 & 2 & 0.805 & $-5.131^{*}$ \\
\hline
\end{tabular}

Notes: 'Authors' abbreviation. ${ }^{2}$ Based on percentage of broken grains and varietal type (see figure 5). ${ }^{3}$ Average price (US\$ ton ${ }^{-1}$ ) for the sample period, Jan 2000 to December 2012. ${ }^{4}$ in $\log$ level, based on AIC. IRPs=international reference prices. *indicates rejection of the null hypothesis of non-stationarity at the 1 percent significance level. Source of raw data: FAO-GIEWS. 
Table 4. Domestic markets and average prices in US\$ ton $^{-1}$

\begin{tabular}{|c|c|c|c|c|c|c|c|c|}
\hline Country & $\begin{array}{c}\text { No. of } \\
\text { markets }\end{array}$ & $\begin{array}{c}\text { Average } \\
\text { price }\end{array}$ & Country & $\begin{array}{c}\text { No. of } \\
\text { markets }\end{array}$ & $\begin{array}{c}\text { Average } \\
\text { price }\end{array}$ & Country & $\begin{array}{c}\text { No. of } \\
\text { markets }\end{array}$ & $\begin{array}{c}\text { Average } \\
\text { price }\end{array}$ \\
\hline Africa & 125 & 787 & Asia & 83 & 493 & Latin America & 61 & 817 \\
\hline Benin & 4 & 727 & Bangladesh & 3 & 320 & Bolivia & 6 & 700 \\
\hline Burkina Faso & 9 & 768 & Bhutan & 2 & 362 & Brazil & 3 & 477 \\
\hline Burundi & 1 & 971 & Cambodia & 4 & 377 & Colombia & 7 & 729 \\
\hline Cameroon & 5 & 767 & China & 4 & 496 & Costa Rica & 2 & 915 \\
\hline Cape Verde & 6 & 919 & India & 8 & 301 & Dominican Republic & 4 & 1,008 \\
\hline Chad & 3 & 919 & Indonesia & 2 & 851 & Ecuador & 5 & 735 \\
\hline Congo & 4 & 983 & Lao & 12 & 630 & El Salvador & 2 & 961 \\
\hline Djibouti & 3 & 863 & Mongolia & 1 & 1,049 & Guatemala & 3 & 788 \\
\hline Egypt & 4 & 597 & Myanmar & 2 & 331 & Haiti & 5 & 1,222 \\
\hline Gabon & 1 & 1,070 & Nepal & 1 & 414 & Honduras & 2 & 854 \\
\hline Ghana & 2 & 937 & Pakistan & 10 & 509 & Mexico & 4 & 895 \\
\hline Guinea & 2 & 615 & Philippines & 28 & 508 & Nicaragua & 10 & 767 \\
\hline Lesotho & 6 & 1,681 & Sri Lanka & 1 & 468 & Panama & 2 & 937 \\
\hline Madagascar & 2 & 547 & Thailand & 2 & 321 & Peru & 4 & 660 \\
\hline Malawi & 2 & 1,123 & Timor Leste & 1 & 736 & Uruguay & 2 & 858 \\
\hline Mali & 14 & 691 & Vietnam & 2 & 392 & & & \\
\hline Mauritania & 1 & 801 & & & & & & \\
\hline Mozambique & 10 & 635 & & & & & & \\
\hline Niger & 12 & 754 & & & & & & \\
\hline Rwanda & 1 & 940 & & & & & & \\
\hline Senegal & 11 & 728 & & & & & & \\
\hline Somalia & 12 & 521 & & & & & & \\
\hline Tanzania & 1 & 790 & & & & & & \\
\hline Togo & 6 & 697 & & & & & & \\
\hline Tunisia & 1 & 706 & & & & & & \\
\hline Uganda & 1 & 824 & & & & & & \\
\hline Zambia & 1 & 1,384 & & & & & & \\
\hline
\end{tabular}


Figure 6. Rice export prices (US\$ ton ${ }^{-1}$ ), Jan 2000 to Dec 2012
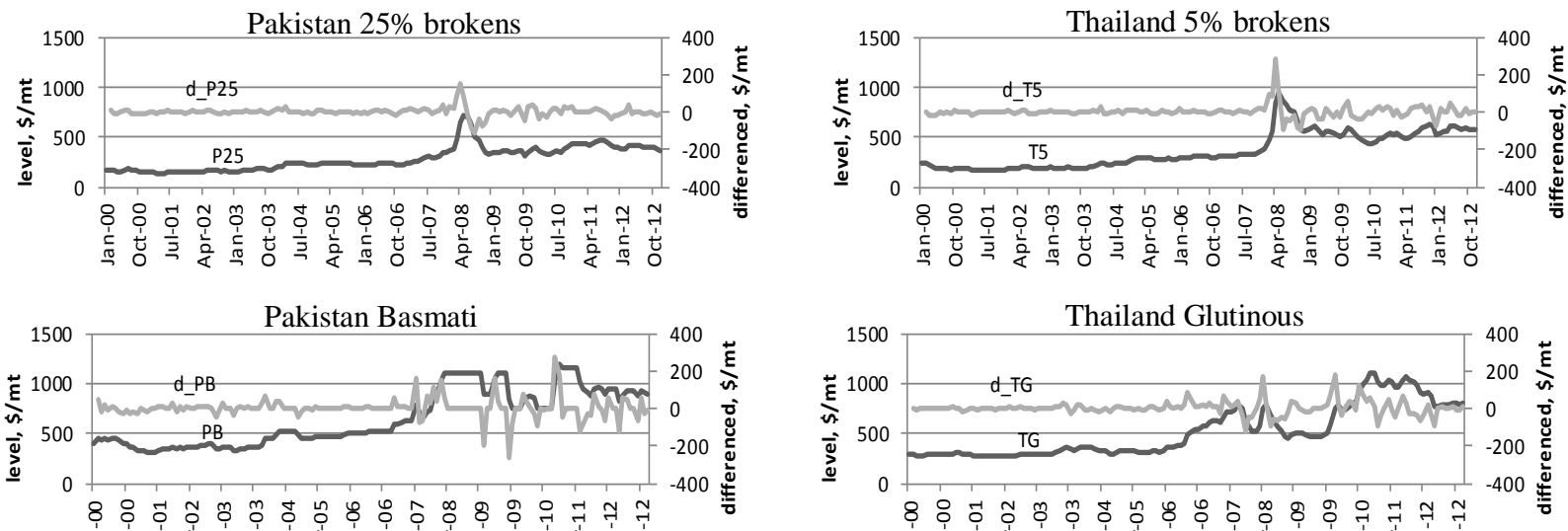

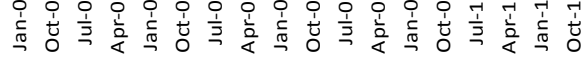

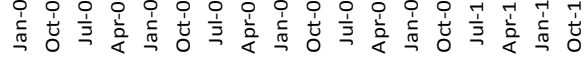

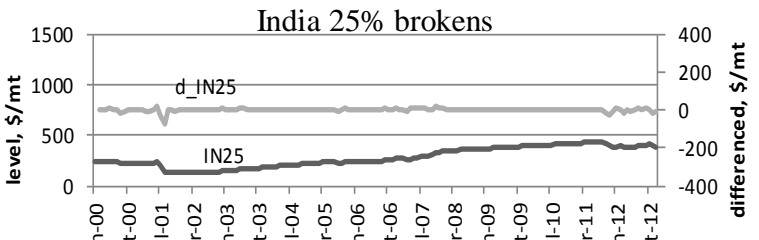

US California Medium
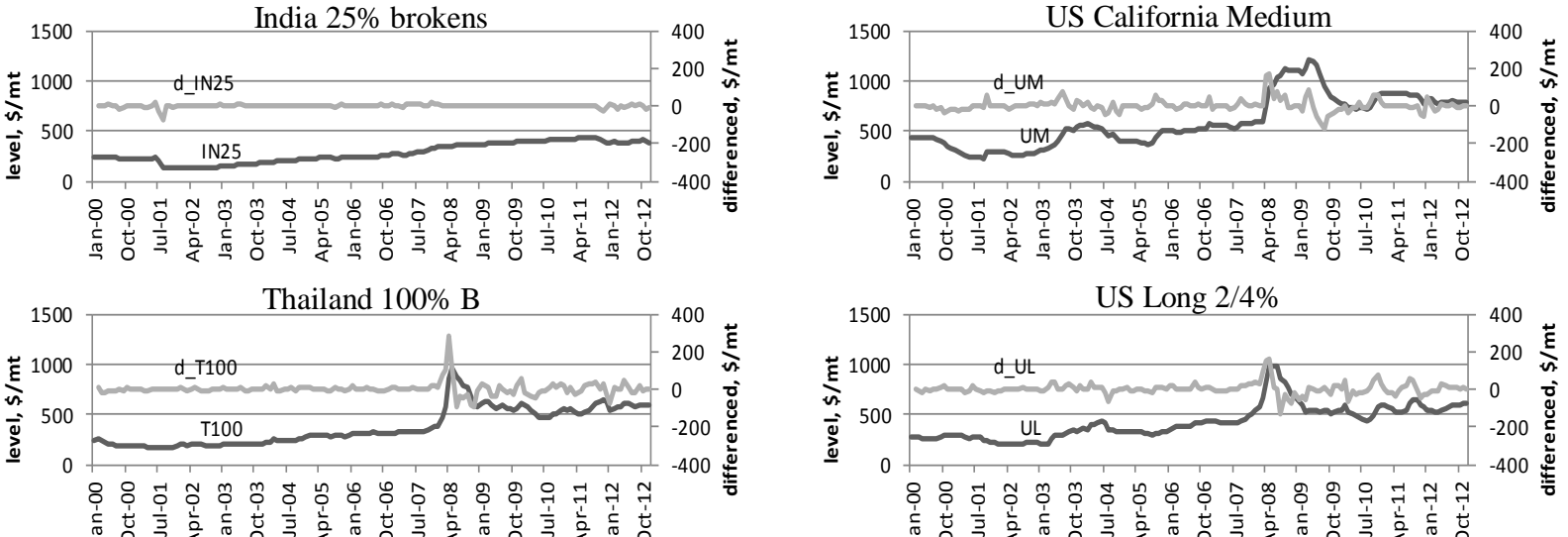

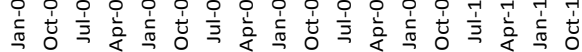
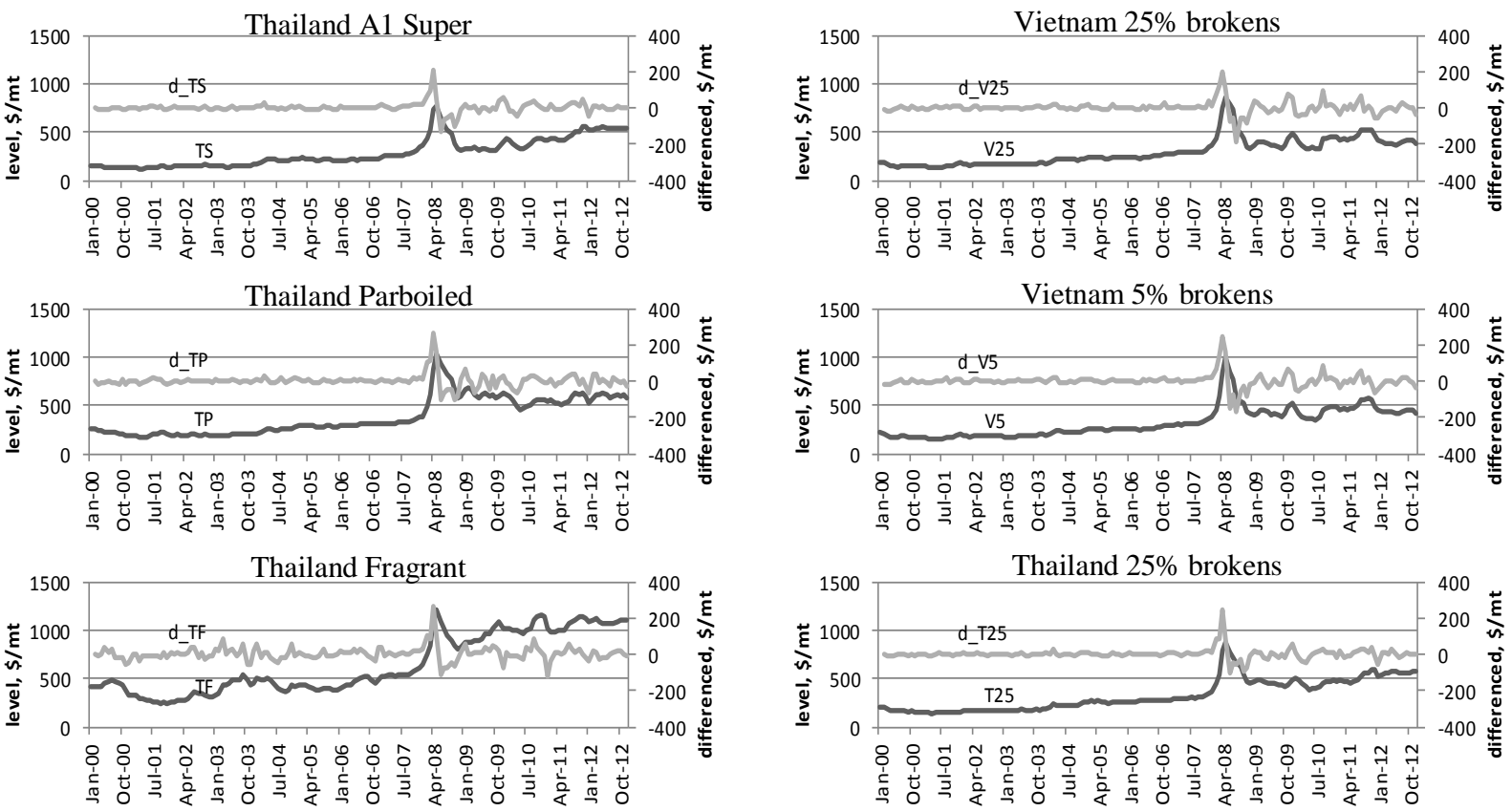

Note: "d_" depicts first differences. Source of raw data: FAO-GIEWS. 
The domestic prices have different starting years, but for consistency, we only use series that begin in January 2000. The minimum length of prices series included in our analysis is $t=17$, but over $70 \%$ of the domestic price series have at least $t=84$ observations. Individual missing values are linearly interpolated. Domestic prices are available for 27 countries in Africa, 16 in Asia, and 15 in Latin America, for a total of 58 countries. Up to 28 individual domestic prices are available for each country, providing us with 269 domestic prices altogether. The AIC reveals one lag in the VECM as optimal in the majority of cases and the Lagrange-multiplier (LM) tests for autocorrelation in the residuals of VECMs reject the presence of autocorrelation in $81 \%$ of all cases using one lag. We, therefore, estimate the VECMs reported below using price series in logarithms with one lag.

\subsection{Results and discussion}

The results of the cointegration tests between the IRP and the domestic rice markets are presented in table 5 . We define the prevalence of cointegration as the number of domestic prices in a country/region that is cointegrated with an IRP. A major observation is that many domestic prices are cointegrated with more than one IRP. Export prices in Vietnam (V25 in the low quality group and V5 in the high quality group) display the highest prevalence of cointegration with domestic prices, especially in Asia and Latin America. Thailand rice (T100, T5, T25, TP, and TF) plays a more important role in many African markets than in Asia. US rice (UL and UM) is cointegrated with only few domestic prices in Asia, but displays a higher prevalence of cointegration with prices in Latin America. Prices in six African countries (Ghana, Malawi, Mauritania, Senegal, Uganda, and Zambia) and one Asian country (Sri Lanka) are not cointegrated with any of the IRP. At the other extreme, at least one domestic price in Mozambique, Somalia, Togo, and Nicaragua is cointegrated with all 14 export rice types. The cointegration analysis also reveals interesting patterns among IRP. Among the export prices, we observe T5 to be cointegrated with about the same markets as T100 (96\% of cases). Similarly, markets that are cointegrated with V25 are also found to be cointegrated with V5 (96\% of cases).

We also find that, while several countries have domestic prices that are cointegrated with an IRP for either high or low quality rice exclusively, price series are cointegrated with both quality types in many countries. The prevalence of cointegration is slightly higher with low quality rice; about $63 \%$ of domestic price series are cointegrated with at least one low quality IRP, while $58 \%$ of markets are cointegrated with at least one high quality IRP. For one, this suggests that low quality rice is gaining ground in global rice trade, particularly for markets and countries that are included in the FAO-GIEWS database. This is in line with USDA (2012) which reports that low quality rice is favored in many African countries not only due to consumer preference but also because of lower import duties. Evidence of cointegration is weakest with I25 and premium export rice types (TG, TF, and UM), but basmati rice (PB) prices appear to be cointegrated with many domestic market prices. For instance, 92 domestic prices in 25 countries are cointegrated with PB. 
Table 5. Prevalence of cointegration by country

\begin{tabular}{|c|c|c|c|c|c|c|c|c|c|c|c|c|c|c|c|c|c|c|c|c|}
\hline \multirow[t]{3}{*}{ Country } & \multirow{3}{*}{$\begin{array}{c}\text { Number } \\
\text { of prices/ } \\
\text { markets }\end{array}$} & \multicolumn{19}{|c|}{ Number of domestic prices cointegrated with the IRP } \\
\hline & & \multicolumn{7}{|c|}{ Low quality } & \multicolumn{6}{|c|}{ High quality } & \multicolumn{5}{|c|}{ Premium quality } & \multirow{2}{*}{$\begin{array}{c}\text { All } \\
\text { potential } \\
\text { IRPs }\end{array}$} \\
\hline & & $\mathbf{I 2 5}$ & $\mathbf{P 2 5}$ & $\mathbf{T 2 5}$ & TS & V25 & & $\begin{array}{l}\text { All } \\
\text { low }\end{array}$ & T100 & T5 & TP & $\mathbf{U L}$ & V5 & $\begin{array}{c}\text { All } \\
\text { high }\end{array}$ & PB & TF & TG & UM & $\begin{array}{c}\text { All } \\
\text { premium }\end{array}$ & \\
\hline$\overline{\text { Asia }}$ & 83 & $\begin{array}{c}\mathbf{3} \\
(4 \%)\end{array}$ & $\begin{array}{c}\mathbf{2 2} \\
(27 \%)\end{array}$ & $\begin{array}{c}\mathbf{1 6} \\
(19 \%)\end{array}$ & $\begin{array}{c}\mathbf{4 3} \\
(52 \%)\end{array}$ & $\begin{array}{c}\mathbf{4 6} \\
(55 \%)\end{array}$ & 55 & $(66 \%)$ & $\begin{array}{c}\mathbf{1 4} \\
(17 \%)\end{array}$ & $\begin{array}{c}\mathbf{1 4} \\
(17 \%)\end{array}$ & $\begin{array}{c}\mathbf{1 0} \\
(12 \%)\end{array}$ & $\begin{array}{c}\mathbf{2} \\
(2 \%)\end{array}$ & $\begin{array}{c}\mathbf{4 5} \\
(54 \%)\end{array}$ & $50(60 \%)$ & $\begin{array}{c}\mathbf{2 6} \\
(31 \%)\end{array}$ & $\begin{array}{c}9 \\
(11 \%)\end{array}$ & $\begin{array}{c}\mathbf{1 1} \\
(13 \%)\end{array}$ & $\begin{array}{c}4 \\
(5 \%)\end{array}$ & $41(49 \%)$ & $66(80 \%)$ \\
\hline South/Central Asia & 30 & 1 & 10 & 5 & 12 & 11 & 17 & $(57 \%)$ & 8 & 8 & 6 & 2 & 11 & $15(50 \%)$ & 3 & 3 & 5 & 2 & $12(40 \%)$ & $21(70 \%)$ \\
\hline Bangladesh & 3 & 0 & 2 & 0 & 0 & 2 & 2 & $(67 \%)$ & 1 & 1 & 1 & 1 & 2 & $3(100 \%)$ & 0 & 0 & 0 & 2 & $2 \quad(67 \%)$ & $3(100 \%)$ \\
\hline Bhutan & 2 & 0 & 1 & 0 & 0 & 1 & 1 & $(50 \%)$ & 2 & 2 & 2 & 1 & 1 & $2(100 \%)$ & 0 & 0 & 0 & 0 & $0 \quad(0 \%)$ & $2(100 \%)$ \\
\hline China & 4 & 0 & 0 & 0 & 1 & 0 & 1 & $(25 \%)$ & 0 & 0 & 0 & 0 & 0 & $0 \quad(0 \%)$ & 0 & 0 & 1 & 0 & $1 \quad(25 \%)$ & $1(25 \%)$ \\
\hline India & 8 & 0 & 3 & 1 & 6 & 3 & 6 & $(75 \%)$ & 1 & 1 & 1 & 0 & 4 & $4(50 \%)$ & 2 & 2 & 3 & 0 & $7 \quad(88 \%)$ & $8(100 \%)$ \\
\hline Mongolia & 1 & 0 & 1 & 0 & 0 & 0 & 1 & $(100 \%)$ & 0 & 0 & 0 & 0 & 0 & $0 \quad(0 \%)$ & 0 & 0 & 0 & 0 & $0 \quad(0 \%)$ & $1(100 \%)$ \\
\hline Nepal & 1 & 1 & 0 & 1 & 1 & 0 & 1 & $(100 \%)$ & 1 & 1 & 1 & 0 & 0 & $1(100 \%)$ & 0 & 1 & 1 & 0 & $1(100 \%)$ & $1(100 \%)$ \\
\hline Pakistan & 10 & 0 & 3 & 3 & 4 & 5 & 5 & $(50 \%)$ & 3 & 3 & 1 & 0 & 4 & $5(50 \%)$ & 1 & 0 & 0 & 0 & $1 \quad(10 \%)$ & $5(50 \%)$ \\
\hline Sri Lanka & 1 & 0 & 0 & 0 & 0 & 0 & 0 & $(0 \%)$ & 0 & 0 & 0 & 0 & 0 & $0(0 \%)$ & 0 & 0 & 0 & 0 & $0 \quad(0 \%)$ & $0 \quad(0 \%)$ \\
\hline Southeast Asia & 53 & 2 & 12 & 11 & 31 & 35 & 38 & $(72 \%)$ & 6 & 6 & 4 & $\mathbf{0}$ & 34 & $35(66 \%)$ & 23 & 6 & 6 & 2 & $29(55 \%)$ & $45(85 \%)$ \\
\hline Cambodia & 4 & 0 & 1 & 1 & 1 & 1 & 1 & $(25 \%)$ & 0 & 0 & 0 & 0 & 1 & $1(25 \%)$ & 0 & 0 & 0 & 0 & $0 \quad(0 \%)$ & $1(25 \%)$ \\
\hline Indonesia & 2 & 0 & 1 & 1 & 2 & 0 & 2 & $(100 \%)$ & 1 & 1 & 1 & 0 & 1 & $1(50 \%)$ & 0 & 2 & 0 & 2 & $2(100 \%)$ & $2(100 \%)$ \\
\hline Lao & 12 & 0 & 2 & 2 & 5 & 5 & 6 & $(50 \%)$ & 1 & 1 & 1 & 0 & 6 & $6(50 \%)$ & 2 & 2 & 2 & 0 & $4 \quad(33 \%)$ & $8(67 \%)$ \\
\hline Myanmar & 2 & 0 & 0 & 0 & 0 & 1 & 1 & $(50 \%)$ & 0 & 0 & 0 & 0 & 0 & $0(0 \%)$ & 0 & 0 & 0 & 0 & $0 \quad(0 \%)$ & $1(50 \%)$ \\
\hline Philippines & 28 & 2 & 6 & 5 & 19 & 24 & 24 & $(86 \%)$ & 2 & 2 & 2 & 0 & 24 & $24(86 \%)$ & 19 & 2 & 2 & 0 & $19(68 \%)$ & $28(100 \%)$ \\
\hline Thailand & 2 & 0 & 2 & 2 & 2 & 2 & 2 & $(100 \%)$ & 1 & 1 & 0 & 0 & 2 & $2(100 \%)$ & 2 & 0 & 0 & 0 & $2(100 \%)$ & $2(100 \%)$ \\
\hline Timor Leste & 1 & 0 & 0 & 0 & 0 & 0 & 0 & $(0 \%)$ & 1 & 1 & 0 & 0 & 0 & $1(100 \%)$ & 0 & 0 & 0 & 0 & $0 \quad(0 \%)$ & $1(100 \%)$ \\
\hline Vietnam & 2 & 0 & 0 & 0 & 2 & 2 & 2 & $(100 \%)$ & 0 & 0 & 0 & 0 & 0 & $0 \quad(0 \%)$ & 0 & 0 & 2 & 0 & $2(100 \%)$ & $2(100 \%)$ \\
\hline
\end{tabular}

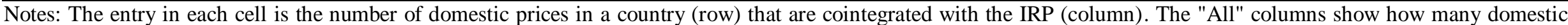

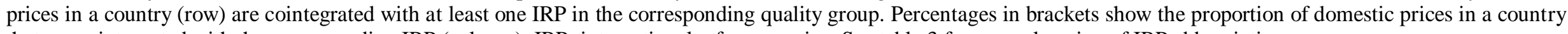
that are cointegrated with the corresponding IRP (column). IRP=international reference price. See table 3 for an explanation of IRP abbreviations. 
Table 5 (continued). Prevalence of cointegration by country

\begin{tabular}{|c|c|c|c|c|c|c|c|c|c|c|c|c|c|c|c|c|c|c|c|}
\hline \multirow[t]{3}{*}{ Country } & \multirow{3}{*}{$\begin{array}{c}\text { Number } \\
\text { of prices/ } \\
\text { markets }\end{array}$} & \multicolumn{18}{|c|}{ Number of domestic prices cointegrated with the IRP } \\
\hline & & \multicolumn{6}{|c|}{ Low quality } & \multicolumn{6}{|c|}{ High quality } & \multicolumn{5}{|c|}{ Premium quality } & \multirow{2}{*}{$\begin{array}{c}\text { All } \\
\text { potential } \\
\text { IRPs }\end{array}$} \\
\hline & & $\mathbf{I 2 5}$ & $\mathbf{P 2 5}$ & T25 & TS & $\mathbf{V 2 5}$ & $\begin{array}{l}\text { All } \\
\text { low }\end{array}$ & T100 & T5 & $\mathbf{T P}$ & $\mathbf{U L}$ & V5 & $\begin{array}{c}\text { All } \\
\text { high }\end{array}$ & PB & TF & TG & UM & $\begin{array}{c}\text { All } \\
\text { premium }\end{array}$ & \\
\hline \multirow[t]{2}{*}{ Africa } & 125 & 18 & 39 & 45 & 43 & 44 & $64(51 \%)$ & 50 & 48 & 45 & 28 & 47 & $61(49 \%)$ & 43 & 33 & 15 & 17 & $70(56 \%)$ & \multirow[t]{2}{*}{$83(66 \%)$} \\
\hline & \multicolumn{7}{|c|}{$(14 \%)(31 \%)(36 \%)(34 \%)(35 \%)$} & \multicolumn{6}{|c|}{$(40 \%)(38 \%)(36 \%)(22 \%)(38 \%)$} & \multicolumn{5}{|c|}{$(34 \%)(26 \%)(12 \%)(14 \%)$} & \\
\hline West/Central Africa & 80 & 8 & 17 & 23 & 20 & 20 & $34(43 \%)$ & 27 & 24 & 22 & 11 & 23 & $31(39 \%)$ & 20 & 18 & 10 & 9 & $40(50 \%)$ & $48(60 \%)$ \\
\hline Benin & 4 & 0 & 4 & 4 & 4 & 4 & $4(100 \%)$ & 4 & 4 & 4 & 2 & 4 & $4(100 \%)$ & 4 & 1 & 0 & 1 & $4(100 \%)$ & $4(100 \%)$ \\
\hline Burkina Faso & 9 & 0 & 0 & 1 & 0 & 0 & $1(11 \%)$ & 1 & 1 & 1 & 0 & 0 & $1(11 \%)$ & 0 & 3 & 5 & 0 & $6 \quad(67 \%)$ & $6(67 \%)$ \\
\hline Cameroon & 5 & 1 & 2 & 2 & 0 & 2 & $4(80 \%)$ & 5 & 4 & 4 & 1 & 2 & $5(100 \%)$ & 4 & 1 & 0 & 1 & $4 \quad(80 \%)$ & $5(100 \%)$ \\
\hline Cape Verde & 6 & 0 & 0 & 1 & 2 & 3 & $3(50 \%)$ & 1 & 0 & 0 & 0 & 3 & $3(50 \%)$ & 0 & 4 & 0 & 0 & $4 \quad(67 \%)$ & $4(67 \%)$ \\
\hline Chad & 3 & 0 & 0 & 1 & 1 & 1 & $1(33 \%)$ & 1 & 1 & 1 & 0 & 1 & $1(33 \%)$ & 1 & 1 & 0 & 1 & $2(67 \%)$ & $2(67 \%)$ \\
\hline Congo & 4 & 1 & 0 & 1 & 1 & 0 & $2(50 \%)$ & 0 & 0 & 0 & 0 & 0 & $0 \quad(0 \%)$ & 0 & 0 & 0 & 0 & $0 \quad(0 \%)$ & $2(50 \%)$ \\
\hline Gabon & 1 & 0 & 0 & 0 & 0 & 0 & $0 \quad(0 \%)$ & 0 & 0 & 0 & 0 & 0 & $0 \quad(0 \%)$ & 0 & 1 & 0 & 0 & $1(100 \%)$ & $1(100 \%)$ \\
\hline Ghana & 2 & 0 & 0 & 0 & 0 & 0 & $0 \quad(0 \%)$ & 0 & 0 & 0 & 0 & 0 & $0 \quad(0 \%)$ & 0 & 0 & 0 & 0 & $0 \quad(0 \%)$ & $0(0 \%)$ \\
\hline Guinea & 2 & 0 & 0 & 0 & 0 & 0 & $0 \quad(0 \%)$ & 0 & 0 & 0 & 0 & 1 & $1(50 \%)$ & 2 & 0 & 0 & 0 & $2(100 \%)$ & $2(100 \%)$ \\
\hline Mali & 14 & 2 & 0 & 1 & 2 & 0 & $4(29 \%)$ & 1 & 1 & 1 & 0 & 0 & $1(7 \%)$ & 0 & 1 & 4 & 0 & $5 \quad(36 \%)$ & $6(43 \%)$ \\
\hline Mauritania & 1 & 0 & 0 & 0 & 0 & 0 & $0 \quad(0 \%)$ & 0 & 0 & 0 & 0 & 0 & $0 \quad(0 \%)$ & 0 & 0 & 0 & 0 & $0 \quad(0 \%)$ & $0 \quad(0 \%)$ \\
\hline Niger & 12 & 0 & 7 & 9 & 8 & 7 & $9(75 \%)$ & 10 & 10 & 8 & 7 & 8 & $10(83 \%)$ & 4 & 1 & 0 & 3 & $7 \quad(58 \%)$ & $10(83 \%)$ \\
\hline Senegal & 11 & 0 & 0 & 0 & 0 & 0 & $0 \quad(0 \%)$ & 0 & 0 & 0 & 0 & 0 & $0(0 \%)$ & 0 & 0 & 0 & 0 & $0 \quad(0 \%)$ & $0(0 \%)$ \\
\hline Togo & 6 & 4 & 4 & 3 & 2 & 3 & $6(100 \%)$ & 4 & 3 & 3 & 1 & 4 & $5(83 \%)$ & 5 & 5 & 1 & 3 & $5 \quad(83 \%)$ & $6(100 \%)$ \\
\hline East/South Africa & 45 & 10 & 22 & 22 & 23 & 24 & $30(67 \%)$ & 23 & 24 & 23 & 17 & 24 & $30(67 \%)$ & 23 & 15 & 5 & 8 & $30(67 \%)$ & $35(78 \%)$ \\
\hline Burundi & 1 & 0 & 0 & 0 & 0 & 1 & $1(100 \%)$ & 0 & 0 & 0 & 0 & 1 & $1(100 \%)$ & 0 & 0 & 0 & 0 & $0 \quad(0 \%)$ & $1(100 \%)$ \\
\hline Djibouti & 3 & 0 & 3 & 1 & 1 & 3 & $3(100 \%)$ & 3 & 3 & 3 & 2 & 3 & $3(100 \%)$ & 3 & 0 & 0 & 2 & $3(100 \%)$ & $3(100 \%)$ \\
\hline Egypt & 4 & 0 & 1 & 0 & 1 & 2 & $2(50 \%)$ & 0 & 0 & 0 & 1 & 2 & $2(50 \%)$ & 0 & 1 & 1 & 0 & $2(50 \%)$ & $4(100 \%)$ \\
\hline Lesotho & 6 & 1 & 0 & 0 & 0 & 0 & $1(17 \%)$ & 0 & 0 & 1 & 1 & 0 & $2(33 \%)$ & 0 & 2 & 0 & 0 & $2(33 \%)$ & $3(50 \%)$ \\
\hline Madagascar & 2 & 1 & 0 & 0 & 0 & 0 & $1(50 \%)$ & 0 & 0 & 0 & 0 & 0 & $0 \quad(0 \%)$ & 1 & 1 & 0 & 0 & $2(100 \%)$ & $2(100 \%)$ \\
\hline Malawi & 2 & 0 & 0 & 0 & 0 & 0 & $0 \quad(0 \%)$ & 0 & 0 & 0 & 0 & 0 & $0 \quad(0 \%)$ & 0 & 0 & 0 & 0 & $0 \quad(0 \%)$ & $0 \quad(0 \%)$ \\
\hline Mozambique & 10 & 3 & 7 & 9 & 9 & 9 & $10(100 \%)$ & 8 & 9 & 8 & 3 & 9 & $10(100 \%)$ & 9 & 4 & 2 & 2 & $10(100 \%)$ & $10(100 \%)$ \\
\hline Rwanda & 1 & 0 & 0 & 1 & 1 & 0 & $1(100 \%)$ & 1 & 1 & 0 & 0 & 0 & $1(100 \%)$ & 0 & 0 & 0 & 0 & $0 \quad(0 \%)$ & $1(100 \%)$ \\
\hline Somalia & 12 & 5 & 9 & 9 & 9 & 7 & $9(75 \%)$ & 9 & 9 & 9 & 9 & 7 & $9(75 \%)$ & 9 & 5 & 2 & 4 & $9 \quad(75 \%)$ & $9(75 \%)$ \\
\hline Tanzania & 1 & 0 & 1 & 1 & 1 & 1 & $1(100 \%)$ & 1 & 1 & 1 & 0 & 1 & $1(100 \%)$ & 0 & 1 & 0 & 0 & $1(100 \%)$ & $1(100 \%)$ \\
\hline Tunisia & 1 & 0 & 1 & 1 & 1 & 1 & $1(100 \%)$ & 1 & 1 & 1 & 1 & 1 & $1(100 \%)$ & 1 & 1 & 0 & 0 & $1(100 \%)$ & $1(100 \%)$ \\
\hline Uganda & 1 & 0 & 0 & 0 & 0 & 0 & $0 \quad(0 \%)$ & 0 & 0 & 0 & 0 & 0 & $0 \quad(0 \%)$ & 0 & 0 & 0 & 0 & $0 \quad(0 \%)$ & $0 \quad(0 \%)$ \\
\hline Zambia & 1 & 0 & 0 & 0 & 0 & 0 & $0 \quad(0 \%)$ & 0 & 0 & 0 & 0 & 0 & $0 \quad(0 \%)$ & 0 & 0 & 0 & 0 & $0 \quad(0 \%)$ & $0 \quad(0 \%)$ \\
\hline
\end{tabular}

N 
Table 5 (continued). Prevalence of cointegration by country

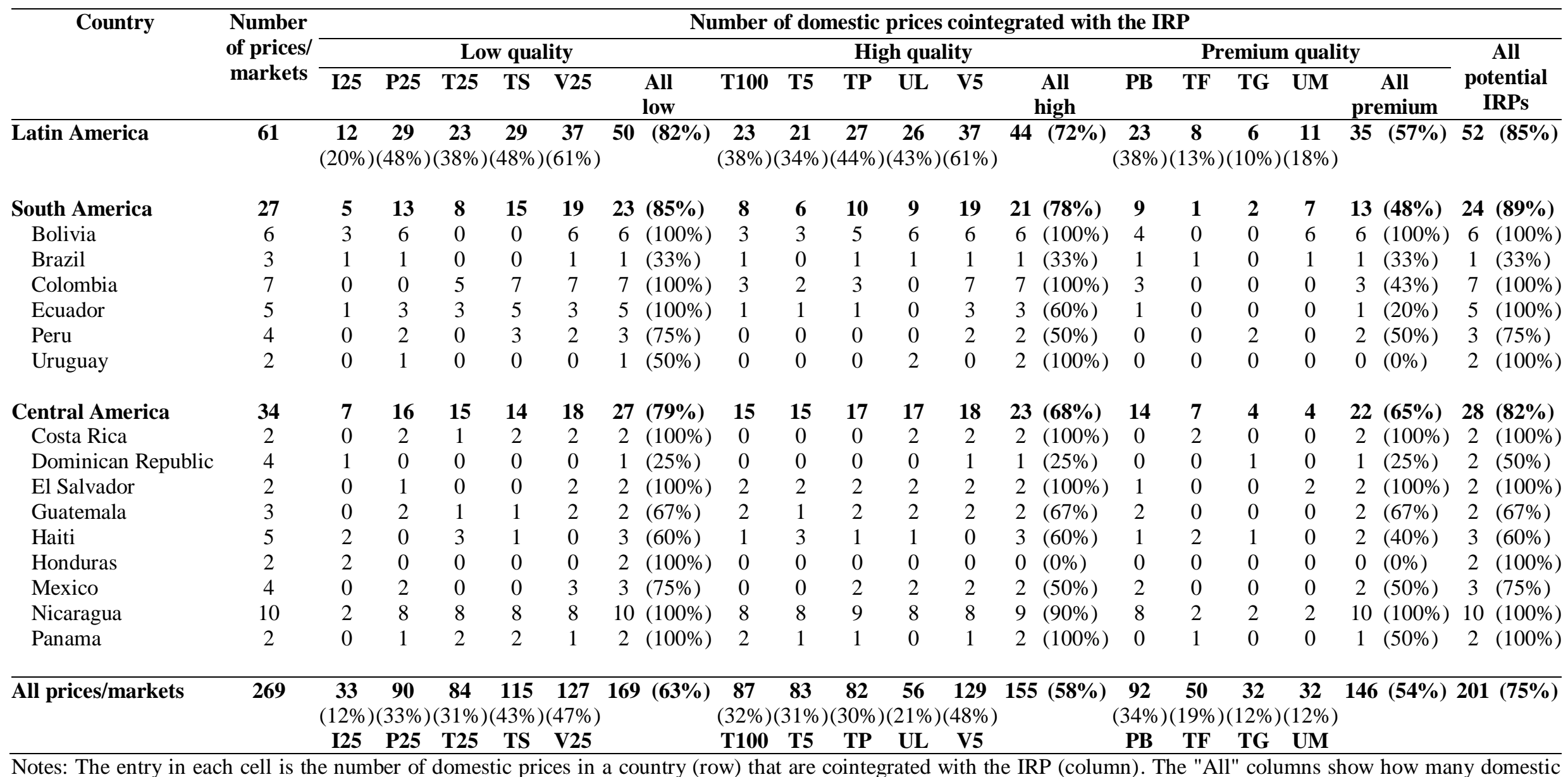

(he proportion of domestic prices in a country that are cointegrated with the corresponding IRP (column). IRP=international reference price. See table 3 for an explanation of IRP abbreviations. 
There are also distinct differences in the prevalence of cointegration within geographical regions (figure 7). Markets in Southeast Asia exhibit higher rates of cointegration than those in South/Central Asia. Export prices in Vietnam appear to be the relevant IRP for markets in Southeast Asia and South America. About 66\% and 64\% of domestic prices in Southeast Asia are cointegrated with V25 and V5, respectively. Similarly, we find 70\% of domestic prices in South America are cointegrated with Vietnam export prices. While there is no single export price that strongly dominates in the African region, price series in East/South Africa have higher prevalence of cointegration compared to markets in West/Central Africa.

When the sample is split pre- and post-December 2007 (figure 8), we find less evidence of cointegration between export and domestic rice prices prior to the food price crisis. This is particularly evident in Asia, where only $45 \%$ of all domestic prices are cointegrated with at least one IRP prior to 2008, but $93 \%$ are cointegrated after. The corresponding shares are $61 \%$ and $84 \%$ in Latin America and 58\% and 64\% in Africa. While the prevalence of cointegration is low in pre-December 2007, we find T100 to be cointegrated with the most number of domestic markets. Post-December 2007, we observe Thailand prices (T100, T5, and TP) to be cointegrated with many domestic markets in Asia.

We investigate the extent of market integration among export rice prices in table 6 and confirm long run relations between price pairs V25-V5 and T100-T5. As in Ghoshray (2008), we also find long run relations between rice export prices of Vietnam and Thailand in the 5\% and $25 \%$ brokens. Basmati rice from Pakistan (PB) appears to be cointegrated with many other IRPs. While TS is relevant for many domestic markets, it does not appear to share long run relationships with Vietnam or other Thailand export prices. I25, TF, TG, UL, and UM are not cointegrated with any other IRPs.

Next, we test for evidence of the LOP within each of the three quality groups using multivariate cointegration analysis (table 7). In none of the clusters do we find that all of the corresponding export prices follow a common stochastic trend, i.e. not all prices within each quality group adhere to the LOP. This supports the assertion that rice types, in general, are not homogenous. The Johansen's trace tests finds one cointegrating relation in the low quality cluster (I25, P25, T25, TS, and V25) and three cointegrating relations in the high quality cluster (T100, T5, TP, UL, and V5). In a similar analysis, Nielsen and Yu (2002), using monthly data from 1990 to 2001, find one cointegrating relation in the low quality cluster (T25, V25, I25, and TS) and two cointegrating relations in the high quality cluster (UL, T100, T5, V5 and I $5^{11}$ ). We find no cointegrating relations in the premium cluster (PB, TF, TG, and UM). This confirms that rice types in the premium category are highly segmented and are not substitutes. Interestingly, we find evidence of cointegration in a cluster that includes export prices from both low and high quality groups. We test for evidence of LOP in a group that includes V25, V5, T5, and T100 because, as reported above, they are cointegrated with the largest number of domestic rice prices. They are also pair-wise cointegrated and share common trends with many other IRPs. We find that these four prices are linked by three cointegrating vectors and, thus, adhere to the LOP.

\footnotetext{
${ }^{11} \mathrm{I} 5=$ India $5 \%$ brokens. This series is not available at the FAO-GIEWS price database.
} 
Figure 7. Prevalence of cointegration by geographical region
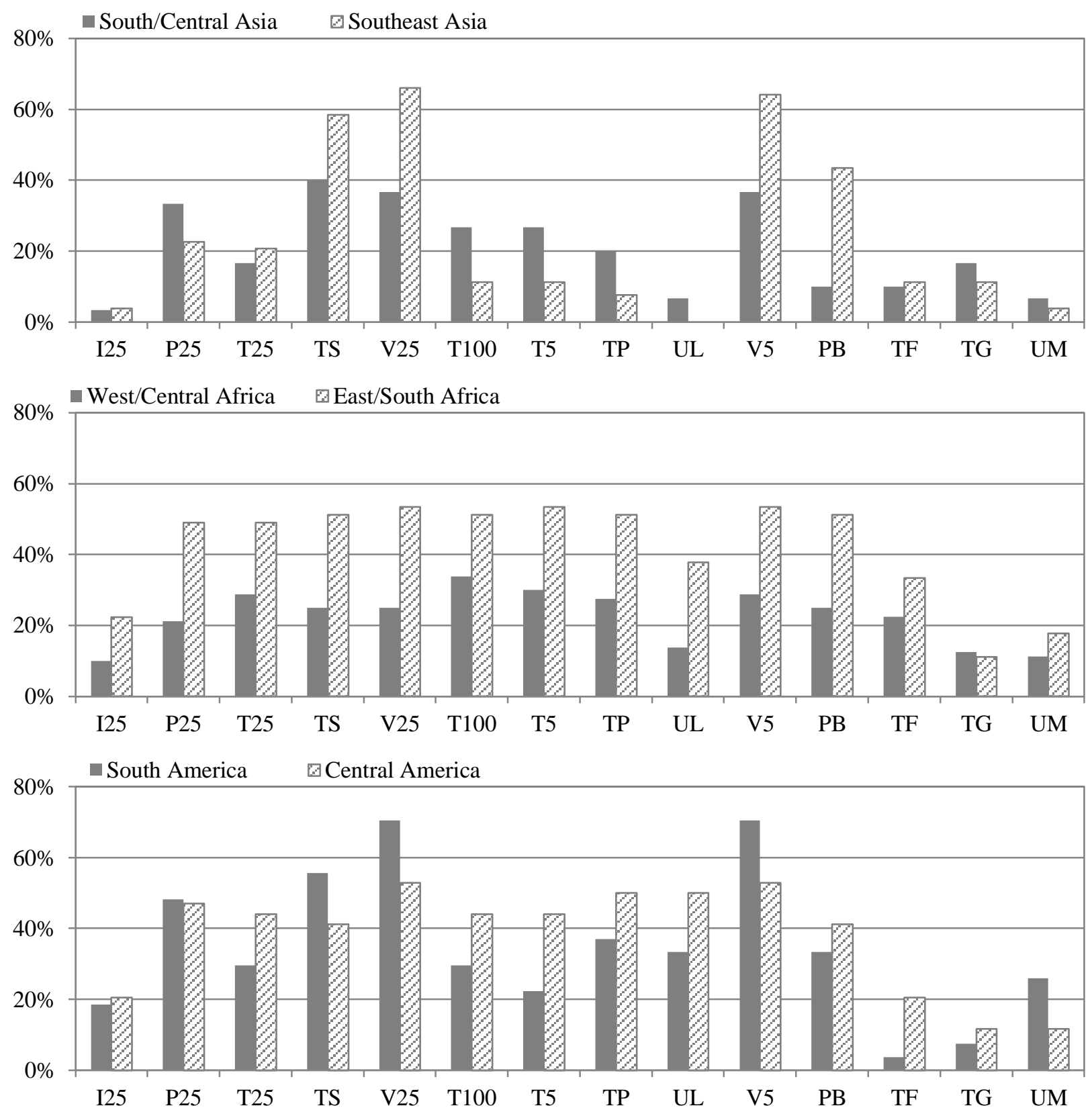

Note: See table 3 for an explanation of IRP abbreviations. 
Figure 8. Prevalence of cointegration by sample period
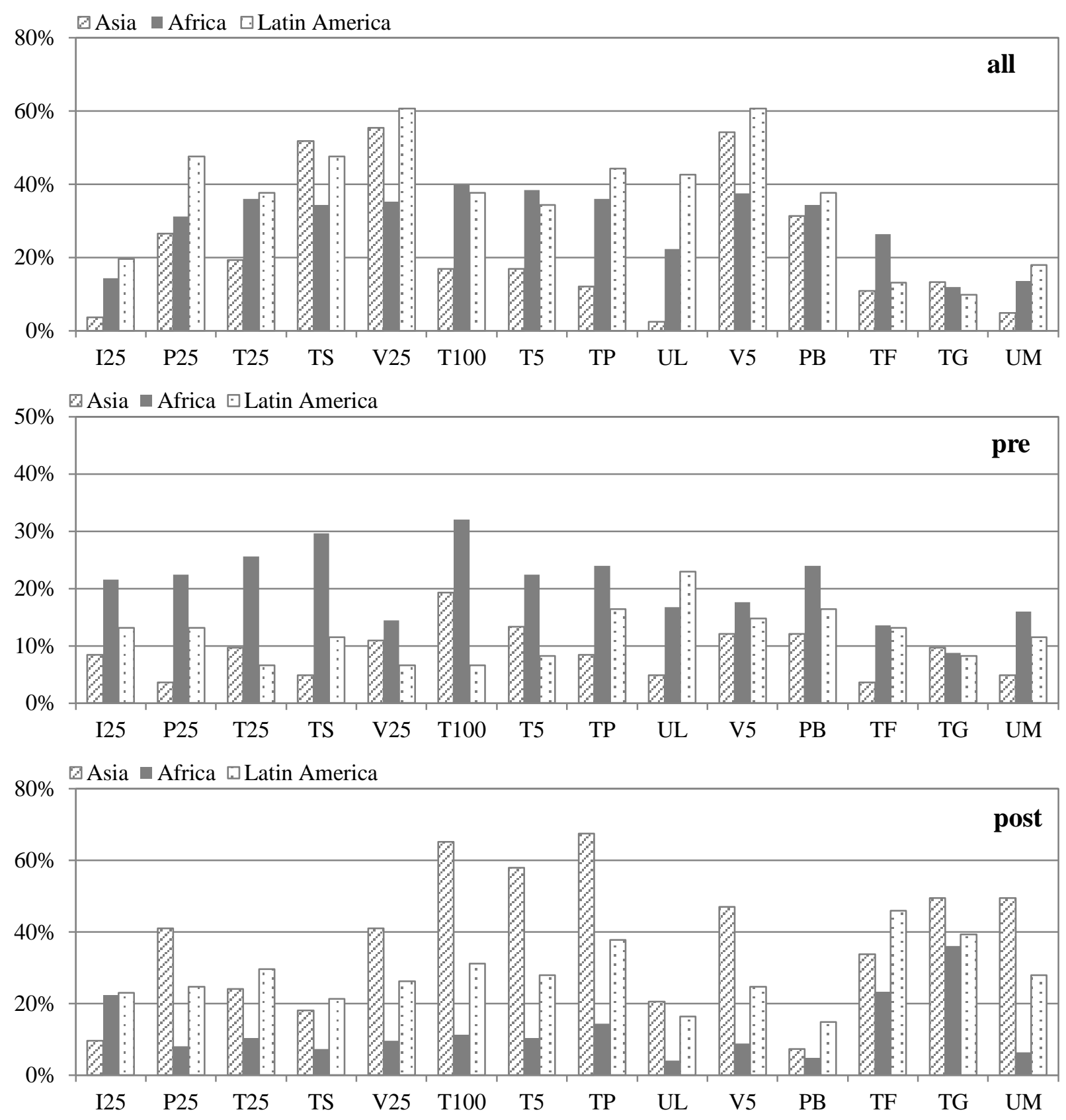

Notes: See table 3 for an explanation of IRP abbreviations. Pre=sample period from Jan 2000 to Dec 2007.

Post=sample period from Jan 2008 to Dec 2012. 
Table 6. Bivariate cointegration tests, $(1=$ cointegrated $)$

\begin{tabular}{|c|c|c|c|c|c|c|c|c|c|c|c|c|c|c|c|}
\hline \multirow{2}{*}{ Quality } & \multirow{2}{*}{ Variety } & \multicolumn{5}{|c|}{ Low quality } & \multicolumn{5}{|c|}{ High quality } & \multicolumn{4}{|c|}{ Premium quality } \\
\hline & & I25 & P25 & T25 & TS & V25 & T100 & T5 & TP & UL & V5 & PB & TF & TG & UM \\
\hline \multirow{5}{*}{$\begin{array}{l}\text { Low } \\
\text { quality }\end{array}$} & I25 & 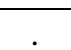 & 0 & 0 & 0 & 0 & 0 & 0 & 0 & 0 & 0 & 0 & 0 & 0 & 0 \\
\hline & P25 & 0 & . & 0 & 0 & 1 & 1 & 1 & 0 & 0 & 1 & 1 & 0 & 0 & 0 \\
\hline & T25 & 0 & 0 & . & 0 & 1 & 0 & 0 & 0 & 0 & 1 & 1 & 0 & 0 & 0 \\
\hline & TS & 0 & 0 & 0 & . & 0 & 0 & 0 & 0 & 0 & 0 & 1 & 0 & 0 & 0 \\
\hline & V25 & 0 & 1 & 1 & 0 & . & 1 & 1 & 1 & 0 & 1 & 1 & 0 & 0 & 0 \\
\hline \multirow{5}{*}{$\begin{array}{l}\text { High } \\
\text { quality }\end{array}$} & T100 & 0 & 1 & 0 & 0 & 1 & . & 1 & 1 & 0 & 1 & 1 & 0 & 0 & 0 \\
\hline & T5 & 0 & 1 & 0 & 0 & 1 & 1 & . & 1 & 0 & 1 & 1 & 0 & 0 & 0 \\
\hline & $\mathbf{T P}$ & 0 & 0 & 0 & 0 & 1 & 1 & 1 & . & 0 & 1 & 1 & 0 & 0 & 0 \\
\hline & $\mathbf{U L}$ & 0 & 0 & 0 & 0 & 0 & 0 & 0 & 0 & . & 0 & 0 & 0 & 0 & 0 \\
\hline & V5 & 0 & 1 & 1 & 0 & 1 & 1 & 1 & 1 & 0 & . & 1 & 0 & 0 & 0 \\
\hline \multirow{4}{*}{$\begin{array}{l}\text { Premium } \\
\text { quality }\end{array}$} & PB & 0 & 1 & 1 & 1 & 1 & 1 & 1 & 1 & 0 & 1 & . & 0 & 0 & 0 \\
\hline & TF & 0 & 0 & 0 & 0 & 0 & 0 & 0 & 0 & 0 & 0 & 0 & . & 0 & 0 \\
\hline & TG & 0 & 0 & 0 & 0 & 0 & 0 & 0 & 0 & 0 & 0 & 0 & 0 & . & 0 \\
\hline & $\mathbf{U M}$ & 0 & 0 & 0 & 0 & 0 & 0 & 0 & 0 & 0 & 0 & 0 & 0 & 0 & . \\
\hline
\end{tabular}

Note: See table 3 for an explanation of IRP abbreviations.

Table 7. Multivariate cointegration tests

\begin{tabular}{lcccc}
\hline Clusters & Rank & Trace statistics & 5\% critical value & ${\text { Reject } \mathbf{H}_{\mathbf{0}}}^{\text {Low quality }}$ \\
I25 P25 T25 TS V25 & 0 & 98.74 & 76.07 & Yes \\
& 1 & $51.90^{*}$ & 53.12 & No \\
& 2 & 22.43 & 34.91 & No \\
& 3 & 10.63 & 19.96 & No \\
\hline High quality & 4 & 1.37 & 9.42 & No \\
T100 T5 TP UL V5 & & & 76.07 & Yes \\
& 1 & 116.15 & 53.12 & Yes \\
& 2 & 62.39 & 34.91 & Yes \\
& 3 & 36.05 & 19.96 & No \\
\hline Premium quality & $15.55^{*}$ & 9.42 & No \\
PB TF TG UM & 4 & 3.11 & 53.12 & No \\
& 0 & & 34.91 & No \\
& 1 & $49.36^{*}$ & 19.96 & No \\
\hline Prevalent & 2 & 19.54 & 9.42 & No \\
T100 T5 V5 V25 & 3 & 8.57 & & Yes \\
& & 2.86 & 53.12 & Yes \\
& 0 & & 34.91 & Yes \\
\hline
\end{tabular}

Notes: Johansen's method for estimating the number of cointegrating relations is to accept the first rank for which the null hypothesis is not rejected. The * indicates the value of rank selected by Johansen' trace test procedure. See table 3 for an explanation of IRP abbreviations. 


\subsection{Conclusion}

Our study contributes to the discussion on rice as a heterogeneous commodity. We find several important results that are particularly relevant for future studies in rice market analysis. First, the prevalence of cointegration between world and domestic rice markets differs by geographical region and by rice type. On average, 201 of 269 (75\%) domestic markets are cointegrated with at least one of the 14 IRPs. We observe slightly higher cointegration rates with low quality (63\%) than with high quality (58\%) rice. We also find greater world to domestic cointegration rates in markets from Southeast Asia (85\% vs. $70 \%$ in South/Central Asia), East/South Africa (78\% vs. 60\% in West/Central Africa), and South America (89\% vs. $82 \%$ in Central America).

Second, using all sample observations, we find that V25 in the low quality cluster and V5 in the high quality cluster are cointegrated with the largest numbers of domestic prices in Asia and Latin America. Thailand prices (T5 and T100) are more dominant in African markets. Our study also points to a structural break in the dynamics of rice prices with the onset of the 2008 food crisis. When observations are split pre- and post-December 2007, we observe higher prevalence of cointegration with T100 as IRP for both periods.

Third, the number of cointegrating vectors, or the rank of the multivariate system, indicates that there is a degree of substitution among export rice types. This suggests that certain rice types, particularly $\mathrm{T} 5, \mathrm{~T} 100, \mathrm{~V} 5$, and $\mathrm{V} 25$, move proportionally to each other in the long run and, thus, can be substitutes as IRP in PT analysis. They are also cointegrated with the largest numbers of domestic markets and with many other IRPs. Focusing on these four prices, we find V25 to be a reasonable IRP for low quality rice. Vietnam is identified as a major exporter of low quality rice and V25 is cointegrated with many export prices. For high quality rice, there is no single answer. The prevalence of cointegration for many local markets in Asia and Latin America markets is higher with V5 using all samples. However, we observe stronger evidence of cointegration with Thailand export prices with sample split and Thailand rice is also relevant for many rice importing countries in Africa.

Our study implies that failure to find cointegrating relations from world to domestic rice markets can be a result of failure to employ an appropriate IRP. We find several export prices to be reasonable IRPs for the rice market, but there is variation across countries, regions, and time period. Hence, in PT analysis, it is imperative to examine the types of rice and to discuss the relevance of specific markets to the benchmark price based on understanding of rice trade structure. We also note that there can be other factors that drive cointegration. For example, policy interventions, which we address in the next chapter, can result to the decoupling of domestic markets from world markets. Nevertheless, this study affirms the importance of having up-to-date and reliable sources of rice prices both in the export and domestic markets, accounting for differences in quality. 


\section{Thresholds in the international rice market ${ }^{12}$}

\subsection{Introduction}

Rice is important for policy analysis because changes in rice prices have a large effect on the purchasing power of the poor. The Asia Society and IRRI (2010) estimate that about 570 million people who live below the US $\$ 1.25$ poverty threshold depend on rice. Large increases in international rice prices, such as occurred in 2008, could have serious negative consequences for these individuals. However, increases in international rice prices may or may not transmit to domestic markets depending on the extent of market integration. Analysis of market integration is based on the law of one price (LOP) according to which the prices of a homogeneous good in two locations should differ by no more than the trade costs (TC) of moving the good from one market to the other (Fackler and Goodwin, 2001). Adherence to LOP is often tested in price transmission (PT) studies, which examine how price changes are transmitted between markets. If PT is rapid, for example due to active arbitrage by traders, then any deviations from LOP are quickly corrected.

Many studies have evaluated the extent to which rice markets are spatially integrated using vector error correction models (VECM) (e.g., Greb et al., 2012; Minot, 2011). ${ }^{13}$ However, these studies largely ignore the role of TC in price transmission. Regression-based tests of market integration result in misleading inferences if TC are not accounted for (Goodwin and Piggott, 2001). In particular, the VECM is misspecified if the price data employed are separated by TC. Since Goodwin and Piggott's (2001) seminal contribution, many authors have used threshold vector error correction models (TVECM) to capture the effects of TC in spatial PT. In such models, thresholds provide estimates of the TC that price deviations must exceed before they trigger spatial arbitrage.

Some studies have applied TVECMs to account for TC in the analysis of rice market integration in individual countries such as Taiwan (Wang and Lee, 2009), Bangladesh (Alam et al., 2012), Madagascar (Moser et al., 2009), Vietnam (Baulch et al., 2008), Benin and Mali (Fiamohe et al., 2013). We contribute to this literature first by analyzing rice PT on 223 rice markets in 47 countries, and second by employing the improved regularized Bayesian TVECM estimator proposed in Greb et al. (2014). ${ }^{14}$ This estimator is less susceptible to bias than the profile likelihood estimator that has been used in the literature to date. This study represents the first attempt to estimate threshold PT processes with a consistent set of price data for a large number of markets and countries using this improved TVECM estimator.

The next section provides a brief description of the TVECM and the regularized empirical Bayesian estimator. Section 4.3 then presents the data employed and the results of our analysis. In section 4.4, we draw conclusions on the nature of PT from international to domestic rice markets.

\footnotetext{
12 This chapter is co-authored with Stephan von Cramon-Taubadel and has been submitted to the Journal of Agricultural Economics.

${ }^{13}$ See also annex 2.

${ }^{14}$ Greb et al. (2014) proposes a regularized empirical Bayesian estimator for general threshold regression models, while Greb et al. (2013) presents the use and performance of this estimator specifically for TVECMs.
} 


\subsection{Methods}

The starting point for models of spatial price behavior is the spatial equilibrium condition implied by the LOP,

$$
p_{1}-p_{2} \leq \mathrm{TC}_{21}
$$

where $p_{i}$ is the price in market $i$, and $T C_{i j}$ are the costs of trade from market $i$ to market $j$ (Fackler and Goodwin, 2001) and may include transaction costs, transportation costs, and policy barrier costs. Spatial PT processes are non-linear, or sometimes referred to as regime-dependent, because the prices on the left hand side are expected to co-move only when the condition in (2) is satisfied as an equality. If equation (2) is satisfied as an inequality, then the two prices can move independently of one another. The TVECM is a piecewise linear regime-dependent model that can capture this type of behavior.

Following Lo and Zivot (2001) and Balke and Fomby (1997), a two-regime, one threshold bivariate TVECM can be represented as follows,

$$
\Delta p_{t}=\left\{\begin{array}{lll}
\alpha_{1}\left(z_{t-1}-\tau\right)+\sum_{j=1}^{k} \beta_{1, j} \Delta p_{t-j}+\varepsilon_{1, t} & \text { if } z_{t-1} \leq \tau & \text { Regime } 1 \\
\alpha_{2}\left(z_{t-1}-\tau\right)+\sum_{j=1}^{k} \beta_{2, j} \Delta p_{t-j}+\varepsilon_{2, t} & \text { if } z_{t-1}>\tau & \text { Regime } 2
\end{array}\right.
$$

where $p_{t}$ is a 2 by $t$ vector of prices being analyzed, $z_{t}$ is the difference between the two prices $[1,-1]^{\prime} p_{\mathrm{t}}$, and $\Delta$ is the first difference operator. The parameters to be estimated in (3) are the $\alpha_{i}$, which are 2 by 1 vectors that contain the so-called adjustment parameters, the threshold parameter $\tau$, and the $k \beta$ s, which are 2 by 2 matrices of parameters that capture short-run dynamics. We expect faster price adjustment when $z_{t}$ is greater than the threshold $\tau$. Hence, the sum of the elements in $\alpha_{2}$ will be larger than the sum of the elements in $\alpha_{1} \cdot{ }^{15}$

The threshold $\tau$ defines the TC that a price difference $z_{t}$ must exceed to elicit responses by one or both prices that 'correct' or reduce the deviation. Threshold autoregressive (TAR) models were first introduced by Tong (1978). Balke and Fomby (1997) extended the TAR by specifying an autoregressive model for the error-correction term implied by the cointegrating relationship. The TVECM is a combination of Tong's TAR model and Engle and Granger's (1987) VECM. The TVECM was first applied to PT for agricultural commodities by Goodwin and Piggott (2001). Hassouneh et al. (2012) provide a summary of recent developments in the econometric analysis of PT with a focus on threshold models.

The estimation of threshold parameters in TVECMs is typically performed using the profile likelihood (PL) estimator (Hansen and Seo, 2002). Essentially, for each possible value of the threshold $\tau$ the model in equation (3) is estimated and the threshold value that results in the model with the best fit is selected as the estimate. This method is sometimes referred to as a grid search because, in models with two or more thresholds, a two- or higher-dimension grid of possible threshold values is searched for the best-fitting model. However, recent work by Greb et al. (2013) show that PL estimation of threshold parameters performs poorly under conditions that

\footnotetext{
${ }^{15}$ See Greb et al.(2013) for a discussion of the expected signs and magnitudes of the adjustment parameters.
} 
are likely to hold in spatial PT settings. They suggest an alternative regularized Bayesian estimator (RBE) that has better small sample properties than the PL estimator and avoids some of its deficiencies (in particular, the need to choose an arbitrary trimming parameter that ensures a sufficient number of observations in each regime). The key to the RBE is the regularization that penalizes differences between regimes so as to keep these differences reasonably small when the data contain little information. As a consequence of this regularization, the posterior density is well-defined over the entire range of the threshold parameter $\tau$, thus eliminating the need to choose an arbitrary trimming parameter.

We check for the significance of threshold effects using the tsDyn package in $\mathrm{R}$ (Antonio et al., 2009) to implement a sup-Wald test proposed by Seo (2006) which tests the null of no cointegration against threshold cointegration with bootstrapped p-values. We estimate a tworegime, one threshold model because none of the countries in our dataset experienced a trade reversal from net imports to net exports, or vice versa, over the sample period. Hence, there is no need for a second threshold and third regime in any of the spatial price relationships that we study. Finally, we modify the model in equation (2) to allow for structural breaks over the sample period. The Gregory-Hansen (1996) tests for cointegration with a structural break indicates that there is a regime shift in many of the price pairs towards the end of 2007 . We therefore modify the TVECM to allow for a structural break in December 2007 which roughly corresponds to the onset of increased volatility in export prices of rice. Essentially, we estimate the model in equation (3) separately for the sub-sample periods before and after December 2007, thus allowing both the threshold and other parameters of the PT relationship between international and domestic rice prices to change once over the sample period.

The estimation strategy can be summarized as follows. First, we evaluate the time series properties of the data using standard Dickey-Fuller unit root tests. Next, we estimate the threshold values and the TVECMs using the RBE proposed by Greb et al. (2013) for the whole sample period and test the significance of threshold effects using Seo's (2006) sup-Wald test. Finally, we split our samples in December 2007 and re-estimate the threshold values and the TVECMs for each of the resulting sub-samples.

\subsection{Empirical application}

The data we analyze includes 223 monthly domestic rice prices extracted from the FAOGIEWS food price database, which was established in 2009 as part of the FAO Initiative on Soaring Food Prices. While the domestic prices have different starting years, we only use data between January 2000 to December 2012 for consistency. The domestic prices cover 26 rice importing countries in Africa, 9 in Asia, and 12 in Latin America. For many of these countries

more than one domestic price series is available, differentiated by location, type of rice, and stage of the marketing chain (i.e. retail and wholesale). It would not be practical to carry out detailed pre-testing and specification searches for each of the many rice prices in the FAOGIEWS database. Standard unit-root tests confirm the presence of unit roots in levels and stationarity in first differences for the great majority of these prices, and we include one lag in all of the TVECMs that we estimate (i.e., $k=2$ in equation 3 ). 
The results of Seo's (2006) sup-Wald tests for the null hypothesis of no cointegration against the alternative of threshold cointegration are reported in (table 8). The p-values for the sup-Wald tests are calculated using a parametric bootstrap with 1,000 replications. To account for segmentation in the world rice market, we first test for cointegration between each individual domestic price and five different prices that are often quoted as international prices: Vietnam 25\% (V25), Thailand 5\% (T5), Vietnam 5\% (V5), Thailand 100B (T100), and Thailand A1 Super (TA1). Overall, we observe the highest prevalence of threshold cointegration when Vietnamese prices are used. Jamora and von Cramon-Taubadel (2012) have also shown that V25 performs well as a measure of international rice prices, and that it is linearly cointegrated with many other commonly used international prices. Hence, we use V25 as the international price in all of the ensuing analysis.

While we cannot confirm threshold cointegration in some price pairs, the sup-Wald test indicates that in 36 of 47 countries at least one domestic price exhibits threshold cointegration with V25. ${ }^{16}$ Hence, we consistently present results for all 223 markets. Table 9 summarizes TVECM estimates by region and country. ${ }^{17}$ The first major observation is that the adjustment parameter estimates are not consistent with spatial arbitrage theory when we estimate over the entire sample period. In this case, it appears that adjustment is more rapid when the price difference is less than the threshold value (in regime 1) than it is when the price difference is greater than the threshold (in regime 2). This suggests that it is inappropriate to estimate over the entire sample period. ${ }^{18}$ Thus, in the following we focus on the results that allow for a structural break between the pre- and post-December 2007 sub-sample periods.

Second, the highest thresholds are estimated for countries in Latin America, the region farthest from our world reference price, and for many land-locked countries in Africa, e.g., Lesotho and Zambia. The magnitude of thresholds also corresponds to the level of protection in the domestic rice economy; i.e., high thresholds indicate wider price margins and greater protection. Comparing thresholds with estimates of nominal rate of assistance (NRA) from Anderson (2009) which measure the extent to which governments raised gross returns to farmers above what they would be without the governments' intervention, we find higher NRA and higher thresholds in countries from Southeast Asia. For example, the average NRA from 2000 to 2007 is 0.452 in the Philippines versus 0.027 in Bangladesh (Anderson and Valenzuela, 2008).

Third, we observe an increase in thresholds if we compare the period prior to December 2007 with the period thereafter. The average threshold estimates correspond to about US\$301 and US $\$ 422$ ton $^{-1}$ in the pre and post periods, respectively, an increase of about $40 \%$ It went up by as much as US\$ 294 ton $^{-1}$ in East/South Africa and US\$ 150 ton $^{-1}$ in South America. Part of the increase in thresholds can be attributed to the increase in energy costs, as a component of freight. For instance, average price of crude oil increased by $48 \%$ from US $\$ 71$ barrel $^{-1}$ in 2007 to US\$105 barrel ${ }^{-1}$ in 2012 (WB Pink Sheet, 2013). Cost to import commodities has also gone up in

\footnotetext{
${ }^{16}$ The exceptions are Mongolia, Indonesia, Lesotho, Rwanda, Tunisia, Uganda Zambia, Guinea, Mauritania, Honduras, and Mexico.

${ }^{17}$ See annex 3 for detailed results.

${ }^{18}$ Similar findings are observed using Vietnam 5\% (V5) as the IRP (annex 4).
} 
the same time period (figure 9). However, the cost of shipping is only one component of TC. ${ }^{19}$ Import tariffs, sales tax, and import quotas contribute to the price margin between world and domestic rice markets. For developing countries that protect domestic rice economy, the trade measures can be substantial. For example, import duty is between $40 \%$ to $50 \%$ in the Philippines. Trade distortions, other than tariffs, is also estimated to be more than $50 \%$ of the price of rice at border in the Philippines (Cororaton, 2006). Further, not all TC are measureable. Barker et al (1985) argue that a significant consequence of a thin global rice trade, both for exporters and importers, is high TC.

Fourth, thresholds are much lower for price series at the wholesale level than at the retail level. This result is illustrated in figure 10. The price difference between the wholesale and the retail markets implicitly measures the mark-up along the rice supply chain and indicates that the price increase post-food crisis is larger at retail than at wholesale level.

Fifth, while the speed of adjustment for rice markets is generally slow, it appears to be more rapid in regions with high level of imports (figure 11). It is 0.296 in Southeast Asia versus 0.077 in South/Central Asia pre-food crisis; 0.228 in Central America versus 0.041 in South America. Similar findings are observed post-food crisis, except that the average speed of adjustment over all countries in the sample slowed down from 0.293 to 0.160 .

Though the general results conform to what we know about spatial arbitrage, there remain cases where the adjustment parameters are larger in magnitude in regime 1 than in regime 2 in pre- and post-food crisis regimes. This implies that some countries are not taking advantage of arbitrage possibilities. Regime 1 obtains when the difference between the world and domestic prices is less than the threshold value and there is no incentive for spatial arbitrage. Regime 2 obtains when the difference between the world and domestic prices exceeds the threshold, which triggers arbitrage and PT. We find 7 out of 47 countries (Indonesia, Laos, Lesotho, Dominican Republic, El Salvador, Bolivia, and Peru) that violate this expectation in both pre- and postDecember 2007 periods. This can be rationalized for Indonesia and Lesotho because for these countries there is no evidence of cointegration between domestic markets and the international price. For countries in Latin America, import volumes are relatively small, ${ }^{20}$ except for Peru which imports mainly from Uruguay (Nolte, 2013). In any case, governments in these countries, and many others, intervened during and after 2008 food crisis to protect domestic markets from high world prices (Demeke et al., 2008; Rapsomanikis, 2009), and these policy responses have restricted spatial arbitrage opportunities.

\footnotetext{
${ }^{19}$ The FAO estimates this to be $12 \%$ of free-on-board (FOB) values, although it could range between $10 \%$ and $35 \%$. Source: http://faostat.fao.org/site/537/default.aspx.

${ }^{20}$ Average import volume in 000 tons from 2008-2011: Laos=32; Dominican Republic=17, El Salvador=61, Bolivia $=17$, Peru=134. Source of raw data: FAOSTAT
} 
Table 8. Prevalence of threshold cointegration

\begin{tabular}{|c|c|c|c|c|c|c|c|c|c|c|c|c|c|}
\hline \multirow{2}{*}{$\frac{\text { Country }}{\text { All markets }}$} & \multirow{2}{*}{$\begin{array}{c}\begin{array}{c}\text { No. of } \\
\text { markets }\end{array} \\
223\end{array}$} & \multicolumn{2}{|c|}{$\begin{array}{c}\text { Vietnam } \\
25 \%\end{array}$} & \multicolumn{2}{|c|}{$\begin{array}{c}\text { Vietnam } \\
5 \%\end{array}$} & \multicolumn{2}{|c|}{$\begin{array}{c}\text { Thailand } \\
5 \% \\
\end{array}$} & \multicolumn{2}{|c|}{$\begin{array}{l}\text { Thailand } \\
100 \% \text { B }\end{array}$} & \multicolumn{2}{|c|}{$\begin{array}{c}\text { Thai A1 } \\
\text { Super }\end{array}$} & \multicolumn{2}{|c|}{$\begin{array}{c}\text { all } \\
\text { IRPs }\end{array}$} \\
\hline & & 137 & $(61 \%)$ & 139 & $(62 \%)$ & 82 & $(37 \%)$ & 65 & $(29 \%)$ & 87 & $(39 \%)$ & 174 & $(78 \%)$ \\
\hline Asia & 51 & 31 & $(61 \%)$ & 31 & $(61 \%)$ & 8 & $(16 \%)$ & 8 & $(16 \%)$ & 11 & $(22 \%)$ & 42 & $(82 \%)$ \\
\hline South/Central Asia & 8 & 5 & $(63 \%)$ & 5 & $(63 \%)$ & 3 & $(38 \%)$ & 1 & $(13 \%)$ & 2 & $(25 \%)$ & 6 & $(75 \%)$ \\
\hline Bangladesh & 3 & 2 & $(67 \%)$ & 3 & $(100 \%)$ & 1 & $(33 \%)$ & 0 & $(0 \%)$ & 1 & $(33 \%)$ & 3 & $(100 \%)$ \\
\hline Bhutan & 2 & 1 & $(50 \%)$ & 0 & $(0 \%)$ & 1 & $(50 \%)$ & 0 & $(0 \%)$ & 0 & $(0 \%)$ & 1 & $(50 \%)$ \\
\hline Mongolia & 1 & 0 & $(0 \%)$ & 0 & $(0 \%)$ & 0 & $(0 \%)$ & 0 & $(0 \%)$ & 0 & $(0 \%)$ & 0 & $(0 \%)$ \\
\hline Nepal & 1 & 1 & $(100 \%)$ & 1 & $(100 \%)$ & 1 & $(100 \%)$ & 1 & $(100 \%)$ & 1 & $(100 \%)$ & 1 & $(100 \%)$ \\
\hline Sri Lanka & 1 & 1 & $(100 \%)$ & 1 & $(100 \%)$ & 0 & $(0 \%)$ & 0 & $(0 \%)$ & 0 & $(0 \%)$ & 1 & $(100 \%)$ \\
\hline Southeast Asia & 43 & 26 & $(60 \%)$ & 26 & $(60 \%)$ & 5 & $(12 \%)$ & 7 & $(16 \%)$ & 9 & $(21 \%)$ & 36 & $(84 \%)$ \\
\hline Indonesia & 2 & 0 & $(0 \%)$ & 0 & $(0 \%)$ & 2 & $(100 \%)$ & 1 & $(50 \%)$ & 0 & $(0 \%)$ & 2 & $(100 \%)$ \\
\hline Laos & 12 & 6 & $(50 \%)$ & 7 & $(58 \%)$ & 2 & $(17 \%)$ & 3 & $(25 \%)$ & 4 & $(33 \%)$ & 9 & $(75 \%)$ \\
\hline Philippines & 28 & 19 & $(68 \%)$ & 19 & $(68 \%)$ & 0 & $(0 \%)$ & 2 & $(7 \%)$ & 4 & $(14 \%)$ & 24 & $(86 \%)$ \\
\hline Timor Leste & 1 & 1 & $(100 \%)$ & 0 & $(0 \%)$ & 1 & $(100 \%)$ & 1 & $(100 \%)$ & 1 & $(100 \%)$ & 1 & $(100 \%)$ \\
\hline Africa & 121 & 79 & $(65 \%)$ & 79 & $(65 \%)$ & 57 & $(47 \%)$ & 45 & $(37 \%)$ & 64 & $(53 \%)$ & 98 & $(81 \%)$ \\
\hline East/South Africa & 41 & 17 & $(41 \%)$ & 18 & $(44 \%)$ & 12 & $(29 \%)$ & 11 & $(27 \%)$ & 16 & $(39 \%)$ & 25 & $(61 \%)$ \\
\hline Burundi & 1 & 1 & $(100 \%)$ & 1 & $(100 \%)$ & 0 & $(0 \%)$ & 0 & $(0 \%)$ & 1 & $(100 \%)$ & 1 & $(100 \%)$ \\
\hline Djibouti & 3 & 3 & $(100 \%)$ & 3 & $(100 \%)$ & 2 & $(67 \%)$ & 1 & $(33 \%)$ & 2 & $(67 \%)$ & 3 & $(100 \%)$ \\
\hline Lesotho & 6 & 0 & $(0 \%)$ & 0 & $(0 \%)$ & 2 & $(33 \%)$ & 2 & $(33 \%)$ & 2 & $(33 \%)$ & 4 & $(67 \%)$ \\
\hline Madagascar & 2 & 2 & $(100 \%)$ & 2 & $(100 \%)$ & 1 & $(50 \%)$ & 0 & $(0 \%)$ & 2 & $(100 \%)$ & 2 & $(100 \%)$ \\
\hline Malawi & 2 & 1 & $(50 \%)$ & 1 & $(50 \%)$ & 0 & $(0 \%)$ & 0 & $(0 \%)$ & 1 & $(50 \%)$ & 1 & $(50 \%)$ \\
\hline Mozambique & 10 & 5 & $(50 \%)$ & 5 & $(50 \%)$ & 2 & $(20 \%)$ & 2 & $(20 \%)$ & 4 & $(40 \%)$ & 5 & $(50 \%)$ \\
\hline Rwanda & 1 & 0 & $(0 \%)$ & 0 & $(0 \%)$ & 0 & $(0 \%)$ & 0 & $(0 \%)$ & 0 & $(0 \%)$ & 0 & $(0 \%)$ \\
\hline Somalia & 12 & 4 & $(33 \%)$ & 4 & $(33 \%)$ & 3 & $(25 \%)$ & 5 & $(42 \%)$ & 3 & $(25 \%)$ & 7 & $(58 \%)$ \\
\hline Tanzania & 1 & 1 & $(100 \%)$ & 1 & $(100 \%)$ & 1 & $(100 \%)$ & 1 & $(100 \%)$ & 1 & $(100 \%)$ & 1 & $(100 \%)$ \\
\hline Tunisia & 1 & 0 & $(0 \%)$ & 0 & $(0 \%)$ & 0 & $(0 \%)$ & 0 & $(0 \%)$ & 0 & $(0 \%)$ & 0 & $(0 \%)$ \\
\hline Uganda & 1 & 0 & $(0 \%)$ & 1 & $(100 \%)$ & 1 & $(100 \%)$ & 0 & $(0 \%)$ & 0 & $(0 \%)$ & 1 & $(100 \%)$ \\
\hline Zambia & 1 & 0 & $(0 \%)$ & 0 & $(0 \%)$ & 0 & $(0 \%)$ & 0 & $(0 \%)$ & 0 & $(0 \%)$ & 0 & $(0 \%)$ \\
\hline
\end{tabular}

Notes: Prevalence of cointegration is measured as the proportion of domestic prices in a country/region that are cointegrated with the corresponding export price

(column), using Seo's sup-Wald test at 5\% significance level, H0: no cointegration | H1: threshold cointegration. 
Table 8 (continued). Prevalence of threshold cointegration

\begin{tabular}{|c|c|c|c|c|c|c|c|c|c|c|c|c|c|}
\hline$\frac{\text { Country }}{\text { West/Central Africa }}$ & $\begin{array}{c}\begin{array}{c}\text { No. of } \\
\text { markets }\end{array} \\
80\end{array}$ & \multicolumn{2}{|c|}{$\begin{array}{c}\text { Vietnam } \\
25 \% \\
\end{array}$} & \multicolumn{2}{|c|}{$\begin{array}{c}\text { Vietnam } \\
5 \% \\
\end{array}$} & \multicolumn{2}{|c|}{$\begin{array}{l}\text { Thailand } \\
5 \%\end{array}$} & \multicolumn{2}{|c|}{$\begin{array}{l}\text { Thailand } \\
100 \% \mathrm{~B}\end{array}$} & \multicolumn{2}{|c|}{$\begin{array}{l}\text { Thai A1 } \\
\text { Super }\end{array}$} & \multicolumn{2}{|c|}{$\begin{array}{l}\text { all } \\
\text { IRPs }\end{array}$} \\
\hline Benin & 4 & 4 & $(100 \%)$ & 4 & $(100 \%)$ & 3 & $(75 \%)$ & 3 & $(75 \%)$ & 3 & $(75 \%)$ & 4 & $(100 \%)$ \\
\hline Cameroon & 5 & 4 & $(80 \%)$ & 4 & $(80 \%)$ & 2 & $(40 \%)$ & 1 & $(20 \%)$ & 4 & $(80 \%)$ & 5 & $(100 \%)$ \\
\hline Cape Verde & 6 & 5 & $(83 \%)$ & 4 & $(67 \%)$ & 4 & $(67 \%)$ & 3 & $(50 \%)$ & 2 & $(33 \%)$ & 6 & $(100 \%)$ \\
\hline Chad & 3 & 1 & $(33 \%)$ & 1 & $(33 \%)$ & 0 & $(0 \%)$ & 0 & $(0 \%)$ & 0 & $(0 \%)$ & 1 & $(33 \%)$ \\
\hline Congo & 4 & 3 & $(75 \%)$ & 3 & $(75 \%)$ & 2 & $(50 \%)$ & 2 & $(50 \%)$ & 2 & $(50 \%)$ & 3 & $(75 \%)$ \\
\hline Guinea & 2 & 0 & $(0 \%)$ & 1 & $(50 \%)$ & 0 & $(0 \%)$ & 0 & $(0 \%)$ & 0 & $(0 \%)$ & 1 & $(50 \%)$ \\
\hline Mali & 14 & 14 & $(100 \%)$ & 13 & $(93 \%)$ & 10 & $(71 \%)$ & 9 & $(64 \%)$ & 11 & $(79 \%)$ & 14 & $(100 \%)$ \\
\hline Mauritania & 1 & 0 & $(0 \%)$ & 1 & $(100 \%)$ & 0 & $(0 \%)$ & 0 & $(0 \%)$ & 0 & $(0 \%)$ & 1 & $(100 \%)$ \\
\hline Niger & 12 & 12 & $(100 \%)$ & 12 & $(100 \%)$ & 6 & $(50 \%)$ & 4 & $(33 \%)$ & 10 & $(83 \%)$ & 12 & (100\%) \\
\hline Senegal & 11 & 10 & $(91 \%)$ & 10 & $(91 \%)$ & 9 & $(82 \%)$ & 8 & $(73 \%)$ & 9 & $(82 \%)$ & 11 & $(100 \%)$ \\
\hline Togo & 6 & 4 & $(67 \%)$ & 4 & $(67 \%)$ & 1 & $(17 \%)$ & 0 & $(0 \%)$ & 3 & $(50 \%)$ & 4 & $(67 \%)$ \\
\hline El Salvador & 2 & 2 & $(100 \%)$ & 2 & $(100 \%)$ & 2 & $(100 \%)$ & 2 & (100\%) & 1 & $(50 \%)$ & 2 & $(100 \%)$ \\
\hline Guatemala & 3 & 1 & $(33 \%)$ & 1 & $(33 \%)$ & 1 & $(33 \%)$ & 1 & $(33 \%)$ & 1 & $(33 \%)$ & 1 & $(33 \%)$ \\
\hline Haiti & 5 & 4 & $(80 \%)$ & 4 & $(80 \%)$ & 3 & $(60 \%)$ & 2 & $(40 \%)$ & 0 & $(0 \%)$ & 5 & $(100 \%)$ \\
\hline Honduras & 2 & 0 & $(0 \%)$ & 1 & $(50 \%)$ & 1 & $(50 \%)$ & 0 & $(0 \%)$ & 0 & $(0 \%)$ & 1 & $(50 \%)$ \\
\hline Mexico & 4 & 0 & $(0 \%)$ & 0 & $(0 \%)$ & 3 & $(75 \%)$ & 3 & $(75 \%)$ & 0 & $(0 \%)$ & 3 & $(75 \%)$ \\
\hline Panama & 2 & 2 & $(100 \%)$ & 2 & $(100 \%)$ & 0 & $(0 \%)$ & 0 & $(0 \%)$ & 0 & $(0 \%)$ & 2 & $(100 \%)$ \\
\hline South America & 17 & 13 & $(76 \%)$ & 13 & $(76 \%)$ & 4 & $(24 \%)$ & 2 & $(12 \%)$ & 6 & $(35 \%)$ & 14 & $(82 \%)$ \\
\hline Bolivia & 6 & 6 & $(100 \%)$ & 6 & $(100 \%)$ & 1 & $(17 \%)$ & 1 & $(17 \%)$ & 4 & $(67 \%)$ & 6 & $(100 \%)$ \\
\hline Colombia & 7 & 4 & $(57 \%)$ & 4 & $(57 \%)$ & 2 & $(29 \%)$ & 1 & $(14 \%)$ & 0 & $(0 \%)$ & 5 & $(71 \%)$ \\
\hline Peru & 4 & 3 & $(75 \%)$ & 3 & $(75 \%)$ & 1 & $(25 \%)$ & 0 & $(0 \%)$ & 2 & $(50 \%)$ & 3 & $(75 \%)$ \\
\hline All markets & 223 & 137 & $(61 \%)$ & 139 & $(62 \%)$ & 82 & $(37 \%)$ & 65 & $(29 \%)$ & 87 & $(39 \%)$ & 174 & $(78 \%)$ \\
\hline
\end{tabular}

Notes: Prevalence of cointegration is measured as the proportion of domestic prices in a country/region that are cointegrated with the corresponding export price

(column), using Seo's sup-Wald test at 5\% significance level, H0: no cointegration |H1: threshold cointegration. 
Table 9. TVECM estimates by country

\begin{tabular}{|c|c|c|c|c|c|c|c|c|c|c|}
\hline \multirow[b]{2}{*}{ Region/Country } & \multirow{2}{*}{$\begin{array}{c}\text { No. of } \\
\text { markets }\end{array}$} & \multicolumn{3}{|c|}{ All sample } & \multicolumn{3}{|c|}{ Pre } & \multicolumn{3}{|c|}{ Post } \\
\hline & & $\tau$ & R.1 & R.2 & $\tau$ & R.1 & R.2 & $\tau$ & R.1 & R.2 \\
\hline All markets & 223 & 226 & 0.625 & 0.080 & 301 & 0.226 & 0.293 & 422 & 0.159 & 0.160 \\
\hline Asia & 51 & 62 & 0.865 & 0.062 & 128 & 0.079 & 0.266 & 213 & 0.149 & 0.141 \\
\hline South/Central Asia & 8 & 19 & 0.364 & 0.134 & 8 & 0.132 & $\mathbf{0 . 0 7 7}$ & 66 & 0.118 & 0.151 \\
\hline Bangladesh & 3 & 5 & 0.152 & 0.152 & 8 & 0.129 & 0.066 & 13 & 0.131 & 0.207 \\
\hline Bhutan & 2 & 3 & 0.132 & 0.164 & 4 & 0.144 & 0.050 & 3 & 0.132 & 0.164 \\
\hline Mongolia* & 1 & 115 & 1.515 & 0.008 & . & . & . & 457 & 0.050 & 0.029 \\
\hline Nepal & 1 & 12 & 0.321 & 0.174 & 7 & 0.100 & 0.100 & 9 & 0.151 & 0.151 \\
\hline Sri Lanka & 1 & 3 & 0.352 & 0.108 & 14 & 0.153 & 0.143 & 12 & 0.083 & 0.083 \\
\hline Southeast Asia & 43 & 70 & 0.958 & 0.049 & 147 & 0.071 & 0.296 & 241 & 0.154 & 0.139 \\
\hline Indonesia* & 2 & 323 & 0.156 & 0.148 & 15 & 0.185 & 0.184 & 323 & 0.156 & 0.148 \\
\hline Laos & 12 & 73 & 0.452 & 0.037 & 99 & 0.101 & 0.099 & 218 & 0.087 & 0.071 \\
\hline Philippines & 28 & 39 & 1.258 & 0.036 & 182 & 0.045 & 0.396 & 239 & 0.180 & 0.161 \\
\hline Timor Leste & 1 & 398 & 0.254 & 0.327 & 2 & 0.200 & 0.099 & 398 & 0.254 & 0.327 \\
\hline Africa & 121 & 236 & 0.647 & 0.092 & 325 & 0.379 & 0.368 & 462 & 0.174 & 0.184 \\
\hline East/South Africa & 41 & 292 & 0.927 & 0.057 & 253 & 0.650 & 0.300 & 547 & 0.099 & 0.122 \\
\hline Burundi & 1 & 101 & 0.000 & 0.017 & 481 & 0.257 & 0.257 & 595 & 0.000 & 0.009 \\
\hline Djibouti & 3 & 208 & 0.525 & 0.062 & 333 & 0.098 & 0.136 & 569 & 0.215 & 0.206 \\
\hline Lesotho* & 6 & 1252 & 0.146 & 0.137 & 380 & 2.826 & 0.221 & 1252 & 0.146 & 0.137 \\
\hline Madagascar & 2 & 65 & 0.410 & 0.111 & 147 & 0.049 & 0.036 & 114 & 0.210 & 0.214 \\
\hline Malawi & 2 & 116 & 0.402 & 0.037 & . & . & . & 740 & 0.048 & 0.089 \\
\hline Mozambique & 10 & 55 & 1.883 & 0.048 & 165 & 0.477 & 0.123 & 372 & 0.130 & 0.144 \\
\hline Rwanda* & 1 & 244 & 0.000 & 0.012 & 477 & 0.020 & 0.020 & 357 & 0.017 & 0.000 \\
\hline Somalia & 12 & 88 & 0.980 & 0.034 & 217 & 0.081 & 0.728 & 358 & 0.027 & 0.102 \\
\hline Tanzania & 1 & 153 & 0.039 & 0.039 & 169 & 0.056 & 0.056 & 153 & 0.014 & 0.014 \\
\hline Tunisia* & 1 & 201 & 1.632 & 0.027 & 335 & 0.115 & 0.115 & 630 & 0.234 & 0.222 \\
\hline Uganda* & 1 & 107 & 1.575 & 0.016 & 244 & 0.029 & 0.029 & 137 & 0.004 & 0.004 \\
\hline Zambia* & 1 & 635 & 0.215 & 0.000 & . & . & . & 1240 & 0.000 & 0.021 \\
\hline
\end{tabular}

Notes: Regional averages are weighted based on number of markets in each country. $\tau=$ threshold. R.1=Regime 1 adjustment parameters from the sum of the elements in $\alpha_{1}$. R.2=Regime 2 adjustment parameters from the sum of the elements in $\alpha_{2}$. “"”not calculated. Pre=sample period from Jan 2000 to Dec 2007. Post=sample period from Jan 2008 to Dec 2012. *not cointegrated with V25. See annex 3 for detailed results. 
Table 9 (continued). TVECM estimates, by country

\begin{tabular}{|c|c|c|c|c|c|c|c|c|c|c|}
\hline \multirow[b]{2}{*}{ Region/Country } & \multirow{2}{*}{$\begin{array}{c}\text { No. of } \\
\text { markets }\end{array}$} & \multicolumn{3}{|c|}{ All sample } & \multicolumn{3}{|c|}{ Pre } & \multicolumn{3}{|c|}{ Post } \\
\hline & & $\tau$ & R.1 & R.2 & $\tau$ & R.1 & R.2 & $\tau$ & R.1 & $\mathbf{R . 2}$ \\
\hline West/Central Africa & 80 & 209 & 0.511 & 0.110 & 365 & 0.228 & 0.406 & 421 & 0.210 & 0.215 \\
\hline Benin & 4 & 171 & 0.106 & 0.039 & 345 & 0.027 & 0.138 & 539 & 0.151 & 0.150 \\
\hline Burkina Faso & 9 & 309 & 0.524 & 0.188 & 335 & 0.058 & 0.735 & 391 & 0.235 & 0.241 \\
\hline Cameroon & 5 & 139 & 0.582 & 0.073 & 349 & 0.112 & 0.143 & 412 & 0.240 & 0.225 \\
\hline Cape Verde & 6 & 384 & 0.684 & 0.114 & 383 & 0.195 & 0.502 & 647 & 0.116 & 0.175 \\
\hline Chad & 3 & 555 & 0.273 & 0.244 & 587 & 0.157 & 0.430 & 584 & 0.207 & 0.242 \\
\hline Congo & 4 & 382 & 0.160 & 0.097 & 503 & 0.157 & 0.589 & 478 & 0.135 & 0.132 \\
\hline Gabon & 1 & 490 & 0.565 & 0.161 & . & . & $\cdot$ & 672 & 0.324 & 0.305 \\
\hline Ghana & 2 & 449 & 0.112 & 0.022 & 506 & 0.045 & 0.069 & 560 & 0.393 & 0.395 \\
\hline Guinea* & 2 & 135 & 0.680 & 0.126 & 253 & 1.522 & 0.219 & 490 & 0.416 & 0.418 \\
\hline Mali & 14 & 186 & 0.430 & 0.176 & 311 & 0.444 & 0.430 & 260 & 0.223 & 0.236 \\
\hline Mauritania* & 1 & 55 & 0.835 & 0.021 & 461 & 0.175 & 0.175 & 226 & 0.010 & 0.010 \\
\hline Niger & 12 & 102 & 0.659 & 0.049 & 400 & 0.110 & 0.469 & 477 & 0.211 & 0.207 \\
\hline Senegal & 11 & 102 & 0.464 & 0.087 & $\cdot$ & $\cdot$ & $\cdot$ & 289 & 0.168 & 0.159 \\
\hline Togo & 6 & 65 & 0.871 & 0.043 & 310 & 0.168 & 0.205 & 476 & 0.263 & 0.251 \\
\hline Latin America & 51 & 378 & 0.327 & 0.073 & 427 & 0.055 & 0.159 & 545 & 0.132 & 0.123 \\
\hline Central America & 34 & 435 & 0.296 & 0.077 & 514 & 0.064 & 0.228 & 589 & 0.144 & 0.149 \\
\hline Costa Rica & 2 & 233 & 0.000 & 0.009 & 472 & 0.118 & 0.118 & 666 & 0.000 & 0.007 \\
\hline Dominican Rep. & 4 & 432 & 0.560 & 0.124 & 663 & 0.093 & 0.090 & 620 & 0.245 & 0.207 \\
\hline El Salvador & 2 & 546 & 0.114 & 0.110 & 404 & 0.090 & 0.076 & 520 & 0.120 & 0.115 \\
\hline Guatemala & 3 & 284 & 0.390 & 0.036 & 367 & 0.090 & 0.087 & 535 & 0.160 & 0.166 \\
\hline Haiti & 5 & 792 & 0.058 & 0.086 & 807 & 0.100 & 0.357 & 888 & 0.076 & 0.121 \\
\hline Honduras* & 2 & 270 & 0.012 & 0.024 & . & . & . & 328 & 0.040 & 0.075 \\
\hline Mexico* & 4 & 683 & 0.146 & 0.049 & 456 & 0.020 & 0.020 & 713 & 0.079 & 0.119 \\
\hline Nicaragua & 10 & 297 & 0.471 & 0.099 & 406 & 0.032 & 0.417 & 443 & 0.200 & 0.187 \\
\hline Panama & 2 & 234 & 0.407 & 0.063 & 439 & 0.054 & 0.054 & 591 & 0.204 & 0.204 \\
\hline South America & 17 & 235 & 0.407 & 0.059 & 282 & 0.043 & 0.041 & 432 & 0.112 & 0.066 \\
\hline Bolivia & 6 & 234 & 0.217 & 0.071 & 277 & 0.074 & 0.071 & 308 & 0.218 & 0.081 \\
\hline Colombia & 7 & 210 & 0.585 & 0.017 & 260 & 0.022 & 0.022 & 529 & 0.017 & 0.030 \\
\hline Peru & 4 & 279 & 0.382 & 0.113 & 329 & 0.033 & 0.029 & 453 & 0.120 & 0.119 \\
\hline All markets & 223 & 226 & 0.625 & 0.080 & 301 & 0.226 & 0.293 & 422 & 0.159 & 0.160 \\
\hline All cointegrated+ & 201 & 186 & 0.649 & 0.081 & 297 & 0.133 & 0.308 & 389 & 0.163 & 0.164 \\
\hline
\end{tabular}

Notes: Regional averages are weighted based on number of markets in each country. $\tau=$ threshold. R.1=Regime 1 adjustment parameters from the sum of the elements in $\alpha_{1}$. R.2=Regime 2 adjustment parameters from the sum of the elements in $\alpha_{2}$."."=not calculated. Pre=sample period from Jan 2000 to Dec 2007. Post=sample period from Jan 2008 to Dec 2012. *not cointegrated with V25. + excluding markets marked with *. See annex 3 for detailed results. 
Figure 9. Cost to import (US\$ ton ${ }^{-1}$ ), 2007 and 2011

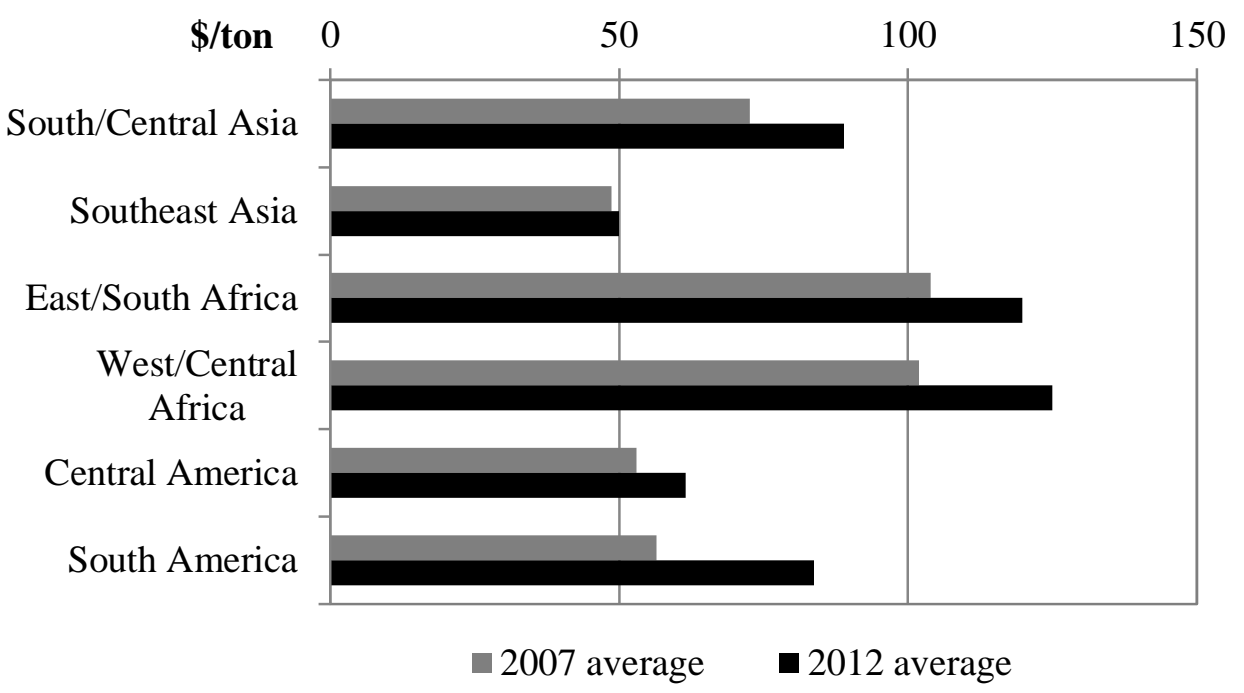

Notes: Regional aggregates for countries included in our sample. Cost measures the fees levied on a 20 -foot container in U.S. dollars, assuming 21 tons of rice per container. Source of raw data: World Bank, Doing Business project (http://www.doingbusiness.org)

Figure 10. Thresholds by price level

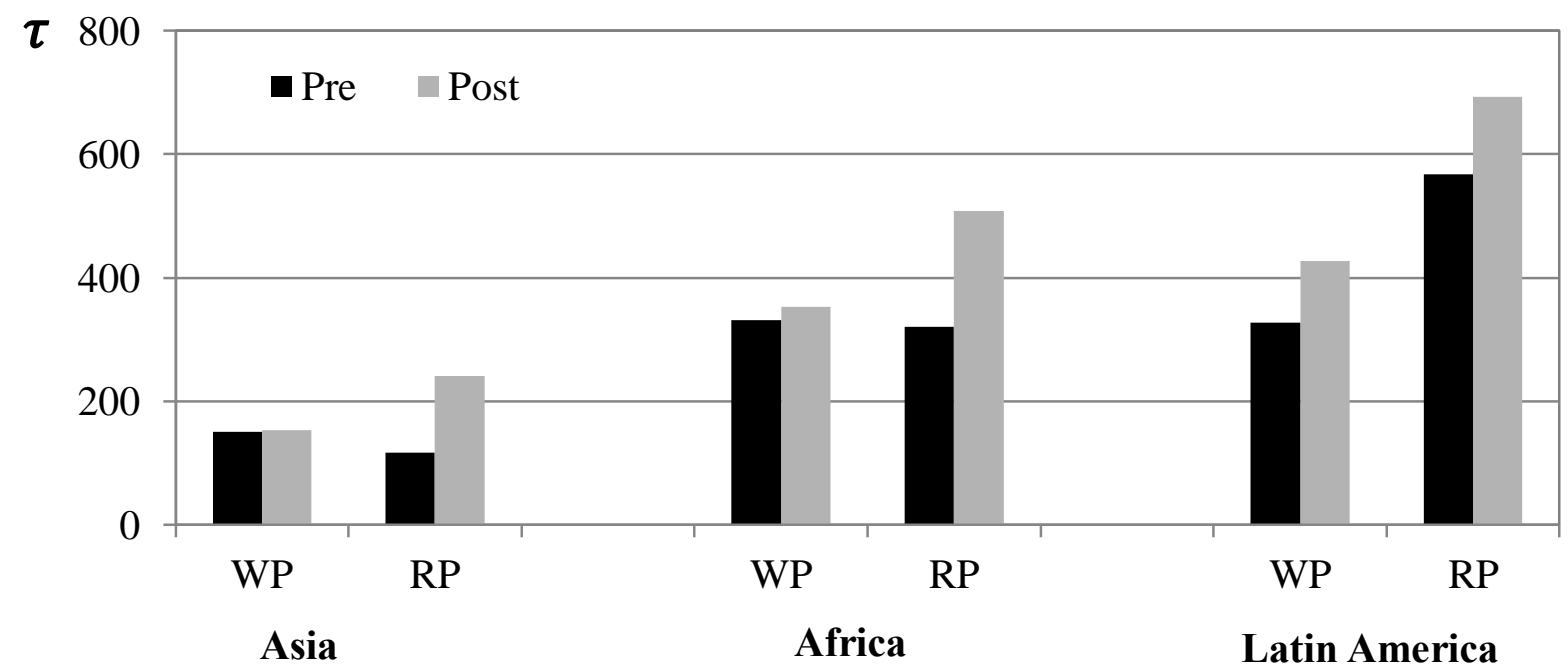

Notes: Average thresholds in post-2008 period. $\mathrm{RP}=$ retail price; $\mathrm{WP}=$ wholesale price. 
Figure 11. Average import volume (000 tons), 2000 to 2011

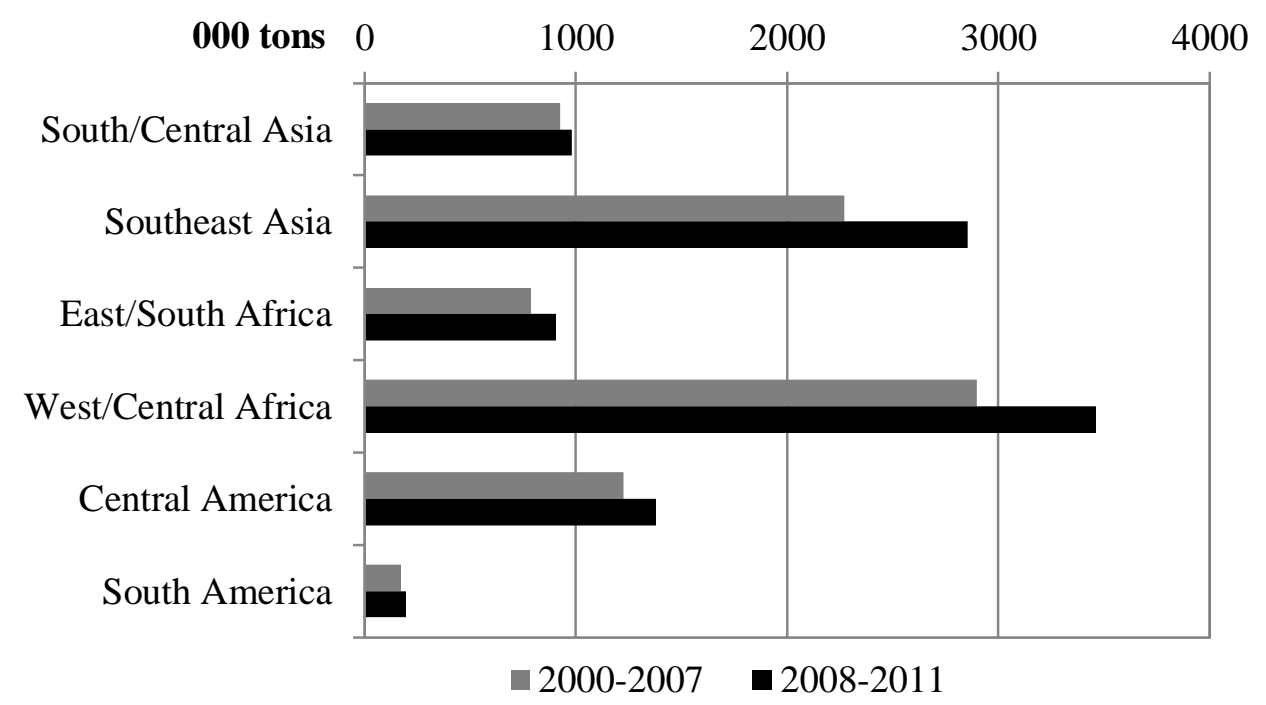

Notes: Regional aggregates for countries included in our sample. Source of raw data: FAOSTAT

To generate further insights into what determines whether individual estimation results are consistent with spatial arbitrage theory, we estimate a logit model in which the dependent variable equals 1 if the results for the country in question are consistent with spatial arbitrage (i.e. adjustment in regime 2 is more rapid than in regime 1) and 0 otherwise. For explanatory variables, we draw on Demeke et al. (2008), who list four types of country responses to the 2008 food price crisis: (1) domestic market measures to reduce prices for consumers (e.g., release of stock at subsidized prices, suspension/reduction of local taxes, price control); (2) trade policy measures to reduce prices for consumers (e.g., reduction of tariffs and import fees, export ban); (3) safety net measures to increase disposable income (e.g., cash transfer, food assistance); and (4) producer oriented measures directed to increase food production (e.g., production safety nets, fertilizer/seeds program), to code a set of dummy variables that reflect the responses chosen by each country in our sample. We control for geographical region and price level and focus on the post-December 2007 estimates that correspond to the food price crisis. We hypothesize that domestic (category 1) and trade (category 2) measures to influence or control local prices may hinder market integration and PT. Producer-oriented measures (category 4) to help boost domestic supply and diminish reliance on imports protect domestic economy and may impede integration with the export market, but these are long-term measures which are unlikely to affect PT in the post-December 2007 period. Safety net measures (category 3) that increase disposable income enhances market integration, assuming higher market participation and consumption as income increases, although it should not affect PT directly.

The results from the logistic regression are presented in table 10. The marginal effects measure the probability that the dependent variable equals 1 (i.e. the TVECM results are consistent with spatial arbitrage) if the policy measure is implemented. Overall, the signs of the coefficients confirm our hypotheses. We find that consistency with spatial arbitrage is less likely in countries that enforce domestic market measures. Trade policy interventions and producer 
support programs also increase the likelihood of inconsistency, but the coefficients are not statistically significant. Measures in category (3), which are designed to increase disposable income of households through safety net programs, do not reduce the likelihood of compliance.

Table 10. Logistic regression, compliance and policy

\begin{tabular}{cccc}
\hline Variables & Average marginal effect & Std. Error & P-value \\
\hline (1) Domestic policy & -0.189 & 0.071 & 0.008 \\
(2) Trade policy & -0.022 & 0.080 & 0.783 \\
(3) Safety net & 0.202 & 0.080 & 0.011 \\
(4) Producer support & -0.057 & 0.083 & 0.491 \\
\hline Africa & 0.222 & 0.086 & 0.010 \\
Asia & 0.187 & 0.104 & 0.073 \\
Retail price & 0.021 & 0.070 & 0.767
\end{tabular}

Log likelihood=-145.157. LR $\operatorname{chi} 2(7)=17.64$. Prob $>$ chi2 $=0.0137$.

Notes: dependent variable $=$ consistency with spatial arbitrage, where consistency $=1$ if the adjustment parameter in regime 2 is greater than in regime 1 as predicted by spatial arbitrage theory, and equal to 0 otherwise. Policy variables from Demeke et al. (2008).

\subsection{Conclusion}

The empirical analysis presented above generates a number of insights into the nature of PT between international and domestic rice markets. The results show an increase in thresholds and a decline in the speed of adjustment post-food crisis. Our estimates point to average threshold estimates of US\$301 and US\$422 ton $^{-1}$ in pre- and post-December 2007 periods, respectively. The average adjustment parameters in regime 2 are 0.293 and 0.160 in the same periods. These findings indicate that price deviations between world and domestic markets have widened in recent years and that there is a certain degree of decoupling of domestic markets from world prices.

The threshold estimates are consistent to the TC view of spatial price relationships in that high thresholds are estimated for countries in Latin America, the region farthest from our international reference price, and for many land-locked countries. However, a major component of thresholds, and thus of TC, are trade distortions from import tariffs, sales tax, and import quotas. These costs suggest that lower thresholds are expected in countries with more marketoriented policy in rice trade.

The TVECM results are also consistent with spatial arbitrage in many rice markets - i.e., price adjustment is more rapid in regime 2, particularly before the food crisis. There are some exceptions, however, to show that these obtain especially for countries that responded in a certain way to the 2008 food price crisis. The results can be rationalized for rice considering the number of distortions introduced by governments that weaken the link between international and 
domestic markets. This is particularly evident in countries that implemented domestic-based policy measures to control local prices.

The results presented here must be interpreted with caution. Because of the large number of domestic prices available in the FAO-GIEWS database, we are not able to carry out a detailed specification search (i.e. determine the optimal number of lags and the optimal break point for each price series). Furthermore, the international price that we use (Viet 25\%) may not be the best possible choice for each individual domestic price that we analyze. Future work could attempt to use programming tools that permit an approach that is more flexible (e.g. comparing results for different lag lengths and international prices) while remaining automated. We also acknowledge that data on actual TC costs could be ideal, but as Baulch (1997) points out, rarely available for analysis.

Policy responses during and after the food price surge in 2008, aimed at protecting consumers, resulted to changes in the dynamics of world to domestic price relationships in rice markets. Our regression shows that direct domestic policy instrument that increase incomes, perhaps through targeted income support to vulnerable groups in the country, could be an option in enhancing market integration instead of averting economic welfare loss through trade and price distortions. Similar policy recommendation was put forward in Anderson and Nelgen (2010). 


\section{Price transmission in the Philippines}

Rice is the single most important source of livelihood among farmers and agricultural workers in the Philippines (Balisacan and Ravago, 2003). It accounts for about $20 \%$ of the country's gross value added in agriculture and is grown on about 4.7 million hectares of arable land. It is also the main source of caloric energy in the Philippines, contributing nearly half of the total caloric intake per person per day (figure 12). Hence, the rice sector is central in the government's agricultural policy and interventions are aimed to achieve "several, often conflicting, objectives" -- to raise income of farmers, provide low prices to consumers, stabilize prices, and attain self-sufficiency (David and Balisacan, 1995).

The Philippines is a traditional net-importer of rice over the last century. While the volume of rice imports has declined since the 2008 food crisis, it imported around 1.8 million tons of rice in 2008, making the country the largest importer in the world for that year. Three main factors explain why the Philippines continue to import rice despite its aggressive food sufficiency policy stance (Dawe et al., 2006). First, the country's natural topography leaves limited arable land to expand rice production. Second, current rice demand, driven largely by population growth rate of around $2 \%$, which is among the world's highest, is outpacing production growth (figure 13). Third, irrigation and transport infrastructures have largely hindered production and marketing expansion in the rice sector.

Figure 12. Share of rice in total caloric food consumption in the Philippines

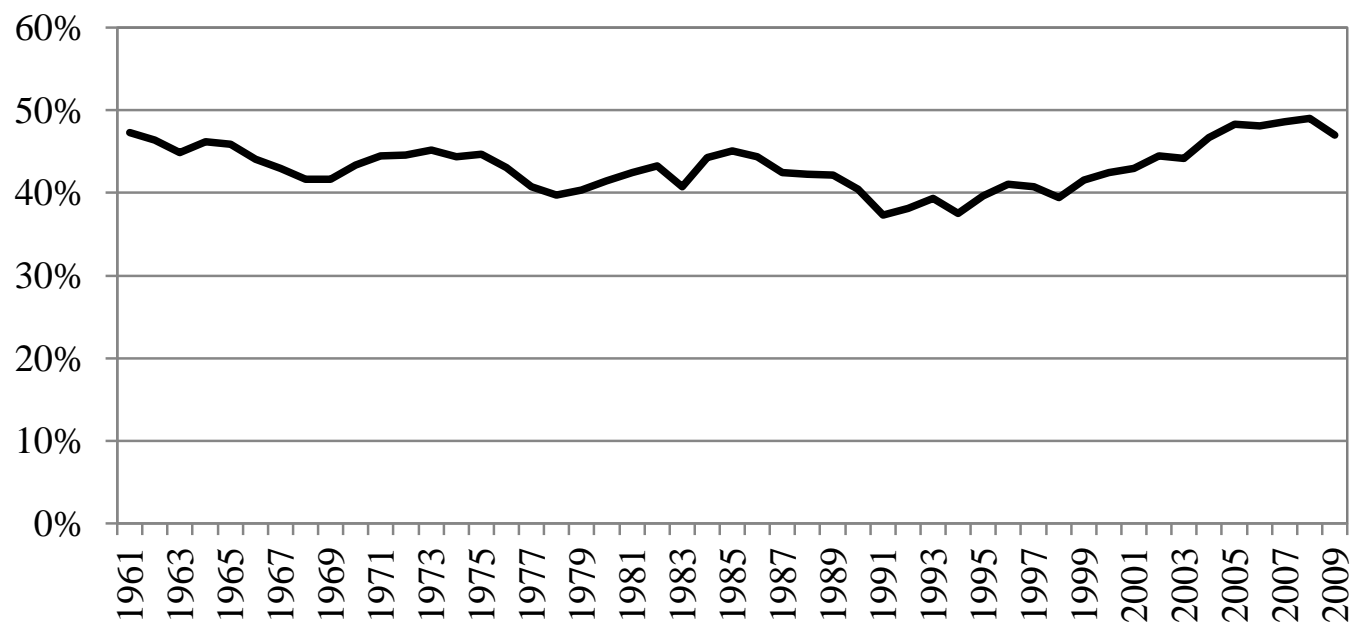

Source of raw data: FAOSTAT. 
Figure 13. Rice demand and supply in the Philippines, 1961 to 2012

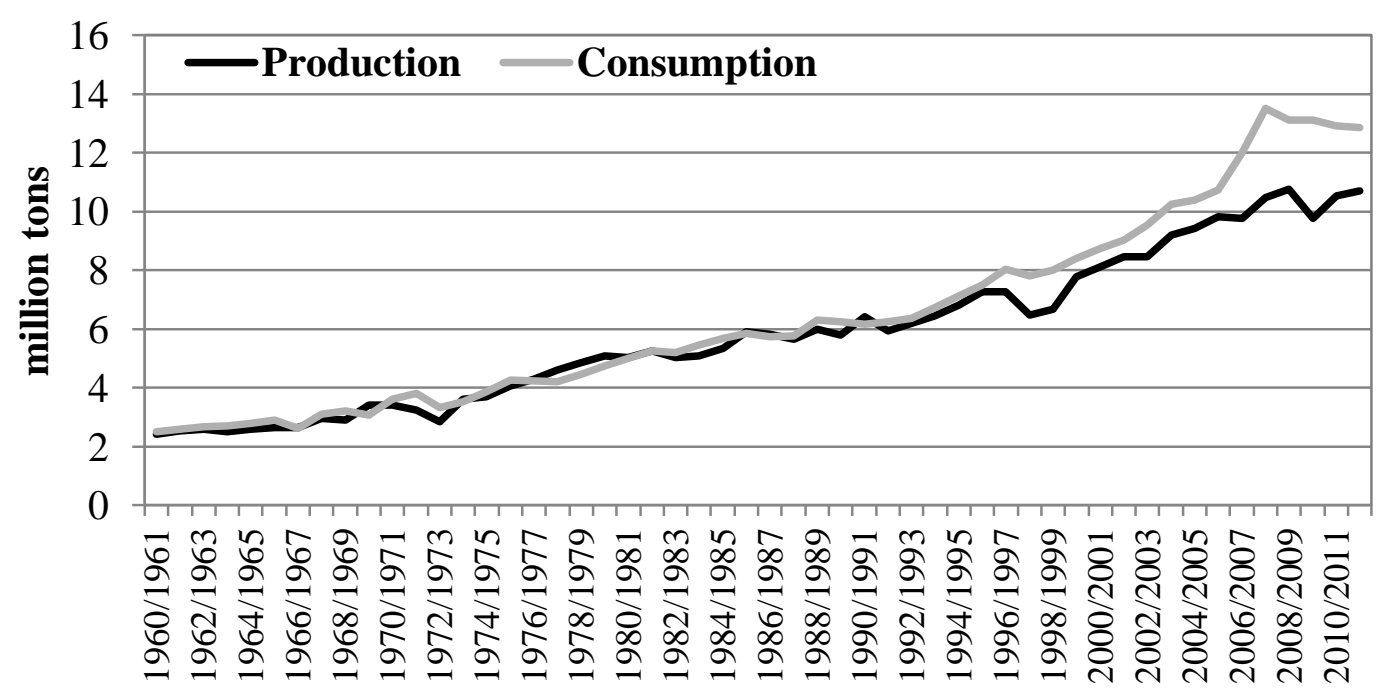

Source of raw data: USDA PS\&D

We examine the cointegration of domestic prices with each international reference price (IRP) using Johansen procedure. From this exercise, we identify which export price shares the most number of cointegrating relationships with our list of domestic markets in the Philippines. The FAO-GIEWS database provides 28 price series for the Philippines in key cities (table 11), disaggregated by milling quality, well-milled (WP) and regular-milled (RP), and by marketing level, wholesale (WP) and retail (RP). WM rice has at most $10 \%$ brokens, while RM rice contains between $10 \%$ to $30 \%$ brokens. On average, there is a $10 \%$ to $11 \%$ premium on prices of WM rice over RM and $8 \%$ to $9 \%$ premium on prices at RP over WP. Domestic prices increased by about 43\% from December 2007 to December 2012. Figure 14 plots monthly price series from 2000 to 2012 and shows widening price differences with Vietnam 25\% brokens (V25). Price margins fluctuated between US $\$ 100$ to US $\$ 300$ before the food crisis and have doubled from around US\$200 in December 2007 to US\$400 in December 2012. Table 12 presents the results of the cointegration tests and shows that majority of domestic markets in the Philippines are cointegrated with Vietnam export prices (V25 and V5). Threshold cointegration tests in table 13 show similar results. For consistency, we present estimates from TVECM using V25 as the IRP in table 14.

The general findings from the Philippines do not diverge from the results of the global price transmission (PT) analysis (chapters 3 and 4) and conform to what we know about spatial arbitrage. We focus on the results which split our sample to pre- and post-December 2007 periods. A graphical inspection of thresholds and regime occurrence indicate that the 2008 food crisis highly influences the dynamics of PT in the sample period (figure 15). Without split, threshold values are consistently estimated during the first few months of 2008, when the price difference goes to zero and the IRP is higher than the domestic price. With sample-split (figure 16), we observe more frequent regime switching activity post-food crisis period and the persistence of regime 1 scenario during the 2008 crisis. Price differences also exceed threshold values consistently for twelve months in 2012. 
Table 11. Average rice prices in the Philippines, US\$ ton ${ }^{-1}$

\begin{tabular}{|c|c|c|c|c|}
\hline Markets/IRP & All sample & Pre & Post & $\begin{array}{c}\text { \% change, } \\
\text { Dec07 - Dec12 }\end{array}$ \\
\hline Philippines & 508 & 385 & 705 & $41 \%$ \\
\hline Well-milled, Retail level & 565 & 429 & 782 & $41 \%$ \\
\hline National Average & 556 & 422 & 771 & $41 \%$ \\
\hline Metro Manila & 570 & 438 & 782 & $37 \%$ \\
\hline Nueva Ecija & 560 & 426 & 775 & $40 \%$ \\
\hline Cebu & 556 & 426 & 765 & $30 \%$ \\
\hline Iloilo & 616 & 469 & 851 & $39 \%$ \\
\hline Davao City & 569 & 427 & 797 & $48 \%$ \\
\hline South Cotabato & 527 & 396 & 736 & $49 \%$ \\
\hline Well-milled, Wholesale level & 501 & 381 & 693 & $40 \%$ \\
\hline National Average & 509 & 384 & 709 & $43 \%$ \\
\hline Metro Manila & 506 & 393 & 686 & $30 \%$ \\
\hline Nueva Ecija & 508 & 387 & 702 & $45 \%$ \\
\hline Cebu & 518 & 393 & 718 & $34 \%$ \\
\hline Iloilo & 462 & 350 & 641 & $52 \%$ \\
\hline Davao City & 529 & 398 & 740 & $41 \%$ \\
\hline South Cotabato & 474 & 359 & 658 & $37 \%$ \\
\hline Regular-milled, Retail level & 508 & 384 & 707 & $41 \%$ \\
\hline National Average & 501 & 379 & 695 & $42 \%$ \\
\hline Metro Manila & 498 & 384 & 680 & $28 \%$ \\
\hline Nueva Ecija & 502 & 384 & 692 & $45 \%$ \\
\hline Cebu & 511 & 389 & 704 & $33 \%$ \\
\hline Iloilo & 549 & 408 & 775 & $45 \%$ \\
\hline Davao City & 502 & 373 & 709 & $48 \%$ \\
\hline South Cotabato & 493 & 368 & 693 & $47 \%$ \\
\hline Regular-milled, Wholesale level & 459 & 348 & 637 & $41 \%$ \\
\hline National Average & 463 & 349 & 645 & $43 \%$ \\
\hline Metro Manila & 463 & 354 & 637 & $38 \%$ \\
\hline Nueva Ecija & 459 & 355 & 624 & $44 \%$ \\
\hline Cebu & 475 & 361 & 657 & $34 \%$ \\
\hline Iloilo & 431 & 327 & 597 & $47 \%$ \\
\hline Davao City & 471 & 350 & 665 & $43 \%$ \\
\hline South Cotabato & 451 & 338 & 631 & $38 \%$ \\
\hline \multicolumn{5}{|l|}{ IRP } \\
\hline V25 & 294 & 205 & 438 & $12 \%$ \\
\hline V5 & 321 & 222 & 480 & $14 \%$ \\
\hline $\mathrm{T} 100$ & 378 & 246 & 591 & $59 \%$ \\
\hline $\mathrm{T} 5$ & 366 & 239 & 570 & $59 \%$ \\
\hline TS & 287 & 187 & 445 & $60 \%$ \\
\hline
\end{tabular}

Notes: Pre=sample period from Jan 2000 to Dec 2007. Post=sample period from Jan 2008 to Dec 2012. IRP=international reference price. See table 3 for an explanation of IRP abbreviations. Source of raw data: FAOGIEWS. 
Figure 14. Rice price trends in the Philippines, 1961 to 2012

(a) Current prices



(b) Price differential from V25

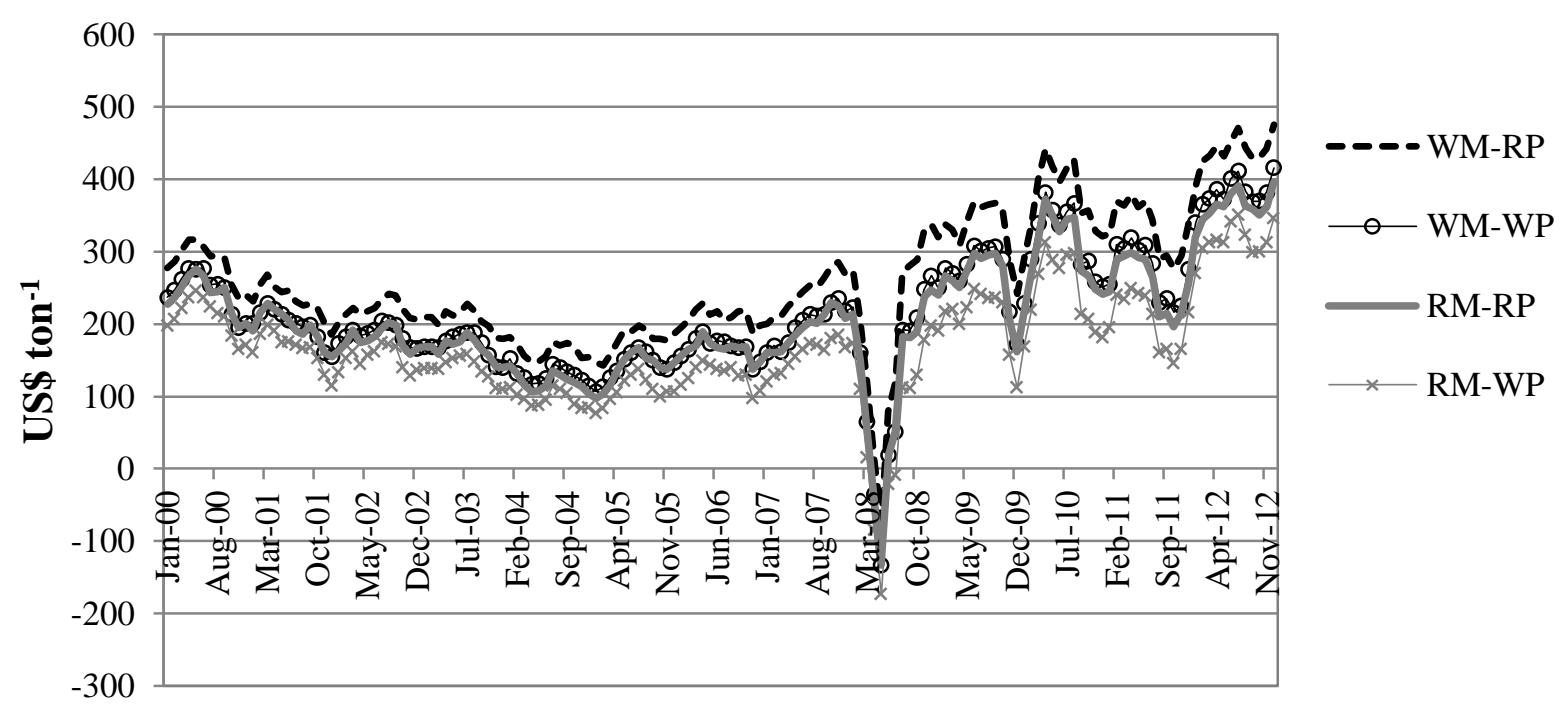

Notes: V25=Vietnam $25 \%$ brokens; $\mathrm{RM}=$ regular-milled rice; $\mathrm{WM}=$ well-milled rice; $\mathrm{RP}=$ retail price; $\mathrm{WP}=$ wholesale price. Source of raw data: FAO-GIEWS. 
Table 12. Prevalence of linear cointegration in domestic markets in the Philippines, $(1=$ cointegrated $)$

\begin{tabular}{|c|c|c|c|c|c|c|c|c|c|c|c|c|c|c|c|c|c|c|}
\hline \multirow{3}{*}{ Markets/IRP } & \multicolumn{18}{|c|}{ Number of domestic prices cointegrated with the IRP } \\
\hline & \multicolumn{6}{|c|}{ Low quality } & \multicolumn{6}{|c|}{ High quality } & \multicolumn{5}{|c|}{ Premium quality } & \multirow{2}{*}{$\begin{array}{c}\text { All } \\
\text { potential } \\
\text { IRPs }\end{array}$} \\
\hline & $\mathbf{I 2 5}$ & $\mathbf{P} 25$ & $\mathbf{T} 25$ & TS & $\mathbf{V 2 5}$ & $\begin{array}{l}\text { All } \\
\text { low }\end{array}$ & T100 & T5 & TP & $\mathbf{U L}$ & $\mathbf{V 5}$ & $\begin{array}{c}\text { All } \\
\text { high }\end{array}$ & PB & TF & TG & UM & $\begin{array}{c}\text { All } \\
\text { premium }\end{array}$ & \\
\hline Philippines & $\begin{array}{c}2 \\
(7 \%) \\
\end{array}$ & $\begin{array}{c}6 \\
(21 \%) \\
\end{array}$ & $\begin{array}{c}5 \\
(18 \%) \\
\end{array}$ & $\begin{array}{c}19 \\
(68 \%) \\
\end{array}$ & $\begin{array}{c}24 \\
(86 \%) \\
\end{array}$ & $\begin{array}{c}24 \\
(86 \%) \\
\end{array}$ & $\begin{array}{c}2 \\
(7 \%) \\
\end{array}$ & $\begin{array}{c}2 \\
(7 \%) \\
\end{array}$ & $\begin{array}{c}2 \\
(7 \%) \\
\end{array}$ & $\begin{array}{c}0 \\
(0 \%) \\
\end{array}$ & $\begin{array}{c}24 \\
(86 \%) \\
\end{array}$ & $\begin{array}{c}24 \\
(86 \%) \\
\end{array}$ & $\begin{array}{c}19 \\
(68 \%) \\
\end{array}$ & $\begin{array}{c}2 \\
(7 \%) \\
\end{array}$ & $\begin{array}{c}2 \\
(7 \%) \\
\end{array}$ & $\begin{array}{c}0 \\
(0 \%) \\
\end{array}$ & $\begin{array}{c}19 \\
(68 \%) \\
\end{array}$ & $\begin{array}{c}28 \\
(100 \%) \\
\end{array}$ \\
\hline Well-milled, Retail level & $\mathbf{0}$ & 4 & 3 & 6 & 6 & 6 & $\mathbf{0}$ & $\mathbf{0}$ & $\mathbf{0}$ & $\mathbf{0}$ & 6 & 6 & 5 & $\mathbf{0}$ & $\mathbf{0}$ & $\mathbf{0}$ & 5 & 7 \\
\hline National Average & 0 & 0 & 0 & 1 & 1 & 2 & 0 & 0 & 0 & 0 & 1 & 1 & 0 & 0 & 0 & 0 & 0 & 4 \\
\hline Metro Manila & 0 & 1 & 0 & 1 & 1 & 3 & 0 & 0 & 0 & 0 & 1 & 1 & 1 & 0 & 0 & 0 & 1 & 5 \\
\hline Nueva Ecija & 0 & 1 & 0 & 1 & 1 & 3 & 0 & 0 & 0 & 0 & 1 & 1 & 1 & 0 & 0 & 0 & 1 & 5 \\
\hline Cebu & 0 & 1 & 1 & 1 & 1 & 4 & 0 & 0 & 0 & 0 & 1 & 1 & 1 & 0 & 0 & 0 & 1 & 6 \\
\hline Iloilo & 0 & 0 & 1 & 1 & 1 & 3 & 0 & 0 & 0 & 0 & 1 & 1 & 0 & 0 & 0 & 0 & 0 & 5 \\
\hline Davao City & 0 & 1 & 1 & 1 & 1 & 4 & 0 & 0 & 0 & 0 & 1 & 1 & 1 & 0 & 0 & 0 & 1 & 6 \\
\hline South Cotabato & 0 & 0 & 0 & 0 & 0 & $\mathbf{0}$ & 0 & 0 & 0 & 0 & 0 & $\mathbf{0}$ & 1 & 0 & 0 & 0 & 1 & 1 \\
\hline Well-milled, Wholesale level & 1 & 1 & 1 & 4 & 7 & 7 & 1 & 1 & $\mathbf{1}$ & $\mathbf{0}$ & 7 & 7 & 4 & 1 & 1 & $\overline{\mathbf{0}}$ & 6 & 7 \\
\hline National Average & 0 & 0 & 0 & 0 & 1 & 1 & 0 & 0 & 0 & 0 & 1 & 1 & 0 & 0 & 0 & 0 & 0 & 3 \\
\hline Metro Manila & 0 & 0 & 0 & 0 & 1 & 1 & 0 & 0 & 0 & 0 & 1 & 1 & 0 & 0 & 0 & 0 & 0 & 3 \\
\hline Nueva Ecija & 0 & 0 & 0 & 0 & 1 & 1 & 0 & 0 & 0 & 0 & 1 & 1 & 0 & 0 & 0 & 0 & 0 & 2 \\
\hline Cebu & 0 & 1 & 0 & 1 & 1 & 3 & 0 & 0 & 0 & 0 & 1 & 1 & 1 & 0 & 0 & 0 & 1 & 5 \\
\hline Iloilo & 0 & 0 & 0 & 1 & 1 & 2 & 0 & 0 & 0 & 0 & 1 & 1 & 1 & 0 & 0 & 0 & 1 & 4 \\
\hline Davao City & 0 & 0 & 0 & 1 & 1 & 2 & 0 & 0 & 0 & 0 & 1 & 1 & 1 & 0 & 0 & 0 & 1 & 4 \\
\hline South Cotabato & 1 & 0 & 1 & 1 & 1 & 4 & 1 & 1 & 1 & 0 & 1 & 4 & 1 & 1 & 1 & 0 & 3 & 11 \\
\hline Regular-milled, Retail level & $\mathbf{0}$ & 1 & $\mathbf{0}$ & 5 & 6 & 6 & $\mathbf{0}$ & $\mathbf{0}$ & $\mathbf{0}$ & $\mathbf{0}$ & 6 & 6 & 4 & $\mathbf{0}$ & $\mathbf{0}$ & $\mathbf{0}$ & 4 & 7 \\
\hline National Average & 0 & 0 & 0 & 0 & 1 & 1 & 0 & 0 & 0 & 0 & 1 & 1 & 0 & 0 & 0 & 0 & 0 & 3 \\
\hline Metro Manila & 0 & 0 & 0 & 1 & 1 & 2 & 0 & 0 & 0 & 0 & 1 & 1 & 1 & 0 & 0 & 0 & 1 & 5 \\
\hline Nueva Ecija & 0 & 1 & 0 & 1 & 1 & 3 & 0 & 0 & 0 & 0 & 1 & 1 & 0 & 0 & 0 & 0 & 0 & 5 \\
\hline Cebu & 0 & 0 & 0 & 1 & 1 & 2 & 0 & 0 & 0 & 0 & 1 & 1 & 1 & 0 & 0 & 0 & 1 & 4 \\
\hline Iloilo & 0 & 0 & 0 & 1 & 1 & 2 & 0 & 0 & 0 & 0 & 1 & 1 & 0 & 0 & 0 & 0 & 0 & 3 \\
\hline Davao City & 0 & 0 & 0 & 0 & 0 & $\mathbf{0}$ & 0 & 0 & 0 & 0 & 0 & $\mathbf{0}$ & 1 & 0 & 0 & 0 & 1 & 1 \\
\hline South Cotabato & 0 & 0 & 0 & 1 & 1 & 2 & 0 & 0 & 0 & 0 & 1 & 1 & 1 & 0 & 0 & 0 & 1 & 4 \\
\hline Regular-milled, Wholesale level & 1 & $\mathbf{0}$ & 1 & 4 & 5 & 5 & 1 & 1 & 1 & $\mathbf{0}$ & 5 & 5 & 6 & 1 & 1 & $\mathbf{0}$ & 8 & 7 \\
\hline National Average & 0 & 0 & 0 & 0 & 0 & $\mathbf{0}$ & 0 & 0 & 0 & 0 & 0 & $\mathbf{0}$ & 1 & 0 & 0 & 0 & 1 & 1 \\
\hline Metro Manila & 0 & 0 & 0 & 0 & 0 & $\mathbf{0}$ & 0 & 0 & 0 & 0 & 0 & $\mathbf{0}$ & 1 & 0 & 0 & 0 & 1 & 1 \\
\hline Nueva Ecija & 0 & 0 & 0 & 0 & 1 & 1 & 0 & 0 & 0 & 0 & 1 & 1 & 0 & 0 & 0 & 0 & 0 & 2 \\
\hline Cebu & 0 & 0 & 0 & 1 & 1 & 2 & 0 & 0 & 0 & 0 & 1 & 1 & 1 & 0 & 0 & 0 & 1 & 4 \\
\hline Iloilo & 0 & 0 & 0 & 1 & 1 & 2 & 0 & 0 & 0 & 0 & 1 & 1 & 1 & 0 & 0 & 0 & 1 & 4 \\
\hline Davao City & 0 & 0 & 0 & 1 & 1 & 2 & 0 & 0 & 0 & 0 & 1 & 1 & 1 & 0 & 0 & 0 & 1 & 4 \\
\hline South Cotabato & 1 & 0 & 1 & 1 & 1 & 4 & 1 & 1 & 1 & 0 & 1 & 4 & 1 & 1 & 1 & 0 & 3 & 11 \\
\hline
\end{tabular}

Note: See table 3 for an explanation of IRP abbreviations. 
Table 13. Prevalence of threshold cointegration in the Philippines, $(1=$ cointegrated $)$

\begin{tabular}{|c|c|c|c|c|c|}
\hline Markets/IRP & $\begin{array}{c}\text { Vietnam } \\
25 \% \\
\end{array}$ & $\begin{array}{c}\text { Vietnam } \\
5 \%\end{array}$ & $\begin{array}{l}\text { Thailand } \\
100 \% \text { B }\end{array}$ & $\begin{array}{c}\text { Thailand } \\
5 \%\end{array}$ & $\begin{array}{c}\text { Thai A1 } \\
\text { Super }\end{array}$ \\
\hline Philippines & $\begin{array}{c}19 \\
(68 \%)\end{array}$ & $\begin{array}{c}19 \\
(68 \%)\end{array}$ & $\begin{array}{c}0 \\
(0 \%)\end{array}$ & $\begin{array}{c}2 \\
(7 \%)\end{array}$ & $\begin{array}{c}4 \\
(14 \%)\end{array}$ \\
\hline Well-milled, Retail level & 4 & 4 & 0 & 0 & 0 \\
\hline National Average & 0 & 0 & 0 & 0 & 0 \\
\hline Metro Manila & 0 & 0 & 0 & 0 & 0 \\
\hline Nueva Ecija & 1 & 1 & 0 & 0 & 0 \\
\hline Cebu & 1 & 1 & 0 & 0 & 0 \\
\hline Iloilo & 1 & 1 & 0 & 0 & 0 \\
\hline Davao City & 1 & 0 & 0 & 0 & 0 \\
\hline South Cotabato & 0 & 1 & 0 & 0 & 0 \\
\hline Well-milled, Wholesale level & 5 & 5 & $\mathbf{0}$ & 1 & $\mathbf{0}$ \\
\hline National Áverage & 0 & 0 & 0 & 1 & 0 \\
\hline Metro Manila & 1 & 1 & 0 & 0 & 0 \\
\hline Nueva Ecija & 1 & 1 & 0 & 0 & 0 \\
\hline Cebu & 1 & 1 & 0 & 0 & 0 \\
\hline Iloilo & 1 & 1 & 0 & 0 & 0 \\
\hline Davao City & 1 & 1 & 0 & 0 & 0 \\
\hline South Cotabato & 0 & 0 & 0 & 0 & 0 \\
\hline Regular-milled, Retail level & 4 & 6 & $\mathbf{0}$ & 1 & 2 \\
\hline National Average & 0 & 1 & 0 & 1 & 0 \\
\hline Metro Manila & 1 & 1 & 0 & 0 & 1 \\
\hline Nueva Ecija & 1 & 1 & 0 & 0 & 1 \\
\hline Cebu & 1 & 1 & 0 & 0 & 0 \\
\hline Iloilo & 0 & 1 & 0 & 0 & 0 \\
\hline Davao City & 0 & 0 & 0 & 0 & 0 \\
\hline South Cotabato & 1 & 1 & 0 & 0 & 0 \\
\hline Regular-milled, Wholesale level & 6 & 4 & $\mathbf{0}$ & $\mathbf{0}$ & 2 \\
\hline National Average & 0 & 1 & 0 & 0 & 0 \\
\hline Metro Manila & 1 & 0 & 0 & 0 & 0 \\
\hline Nueva Ecija & 1 & 1 & 0 & 0 & 0 \\
\hline Cebu & 1 & 1 & 0 & 0 & 0 \\
\hline Iloilo & 1 & 1 & 0 & 0 & 1 \\
\hline Davao City & 1 & 0 & 0 & 0 & 0 \\
\hline South Cotabato & 1 & 0 & 0 & 0 & 1 \\
\hline
\end{tabular}


Table 14. Threshold estimates in the Philippines

\begin{tabular}{|c|c|c|c|c|c|c|c|c|c|}
\hline \multirow[b]{2}{*}{ Markets } & \multicolumn{3}{|c|}{ All sample } & \multicolumn{3}{|c|}{ Pre } & \multicolumn{3}{|c|}{ Post } \\
\hline & $\tau$ & R.1 & R.2 & $\tau$ & R.1 & R.2 & $\tau$ & R.1 & R.2 \\
\hline Philippines & 39 & 1.258 & 0.036 & 182 & 0.045 & 0.396 & 239 & 0.180 & 0.161 \\
\hline Well-milled, Retail level & 74 & 1.442 & 0.042 & 225 & 0.040 & 0.177 & 355 & 0.220 & 0.197 \\
\hline National Average & 15 & 1.728 & 0.022 & 210 & 0.040 & 0.041 & 330 & 0.200 & 0.159 \\
\hline Metro Manila & 135 & 0.614 & 0.053 & 290 & 0.039 & 0.689 & 377 & 0.257 & 0.257 \\
\hline Nueva Ecija & 75 & 0.980 & 0.067 & 226 & 0.046 & 0.046 & 353 & 0.278 & 0.271 \\
\hline Cebu & 55 & 1.310 & 0.057 & 290 & 0.013 & 0.345 & 360 & 0.276 & 0.263 \\
\hline Iloilo & 145 & 1.387 & 0.038 & 238 & 0.049 & 0.049 & 475 & 0.240 & 0.216 \\
\hline Davao City & 15 & 2.603 & 0.018 & 167 & 0.057 & 0.032 & 340 & 0.130 & 0.142 \\
\hline South Cotabato & 75 & 1.472 & 0.039 & 153 & 0.035 & 0.035 & 250 & 0.157 & 0.071 \\
\hline Well-milled, Wholesale level & 40 & 1.101 & 0.039 & 188 & 0.047 & 0.985 & 219 & 0.170 & 0.155 \\
\hline National Average & 19 & 1.294 & 0.033 & 228 & 0.032 & 0.063 & 260 & 0.170 & 0.136 \\
\hline Metro Manila & 15 & 1.139 & 0.033 & 199 & 0.064 & 0.064 & 270 & 0.310 & 0.276 \\
\hline Nueva Ecija & 94 & 0.600 & 0.058 & 181 & 0.058 & 0.058 & 274 & 0.226 & 0.226 \\
\hline Cebu & 25 & 1.295 & 0.040 & 241 & 0.030 & 0.582 & 310 & 0.268 & 0.268 \\
\hline Iloilo & 41 & 0.674 & 0.039 & 98 & 0.084 & 0.074 & 170 & 0.175 & 0.086 \\
\hline Davao City & 75 & 1.527 & 0.041 & 253 & 0.027 & 6.024 & 230 & 0.039 & 0.075 \\
\hline South Cotabato & 12 & 1.181 & 0.028 & 117 & 0.033 & 0.033 & 21 & 0.000 & 0.021 \\
\hline Regular-milled, Retail level & 23 & 1.380 & 0.031 & 163 & 0.036 & 0.171 & 255 & 0.203 & 0.175 \\
\hline National Average & 19 & 1.269 & 0.033 & 195 & 0.022 & 0.047 & 245 & 0.173 & 0.123 \\
\hline Metro Manila & 15 & 1.135 & 0.034 & 126 & 0.037 & 0.026 & 287 & 0.325 & 0.292 \\
\hline Nueva Ecija & 9 & 1.251 & 0.023 & 147 & 0.002 & 0.009 & 260 & 0.217 & 0.217 \\
\hline Cebu & 15 & 1.335 & 0.030 & 250 & 0.053 & 0.983 & 283 & 0.259 & 0.250 \\
\hline Iloilo & 29 & 1.174 & 0.026 & 173 & 0.072 & 0.072 & 365 & 0.253 & 0.207 \\
\hline Davao City & 31 & 1.700 & 0.037 & 139 & 0.023 & 0.022 & 210 & 0.196 & 0.082 \\
\hline South Cotabato & 45 & 1.793 & 0.037 & 112 & 0.040 & 0.040 & 132 & 0.000 & 0.056 \\
\hline Regular-milled, Wholesale level & 20 & 1.107 & 0.033 & 154 & 0.059 & 0.250 & 126 & 0.126 & 0.116 \\
\hline National Average & 15 & 1.200 & 0.027 & 165 & 0.015 & 0.046 & 197 & 0.200 & 0.152 \\
\hline Metro Manila & 1 & 2.039 & 0.015 & 171 & 0.113 & 0.106 & 158 & 0.156 & 0.161 \\
\hline Nueva Ecija & 60 & 0.603 & 0.062 & 157 & 0.080 & 0.080 & 160 & 0.181 & 0.177 \\
\hline Cebu & 29 & 1.195 & 0.059 & 196 & 0.016 & 0.471 & 244 & 0.315 & 0.257 \\
\hline Iloilo & 1 & 0.613 & 0.018 & 95 & 0.104 & 0.104 & 12 & 0.020 & 0.020 \\
\hline Davao City & 35 & 1.378 & 0.035 & 194 & 0.039 & 0.897 & 109 & 0.000 & 0.039 \\
\hline South Cotabato & 1 & 0.723 & 0.016 & 97 & 0.044 & 0.044 & 1 & 0.009 & 0.009 \\
\hline
\end{tabular}

Notes: Pre=sample period from Jan 2000 to Dec 2007. Post=sample period from Jan 2008 to Dec 2012. 
Figure 15. Thresholds and regime-switching, Philippines (national average, all sample)

(a) Well-milled, Retail price

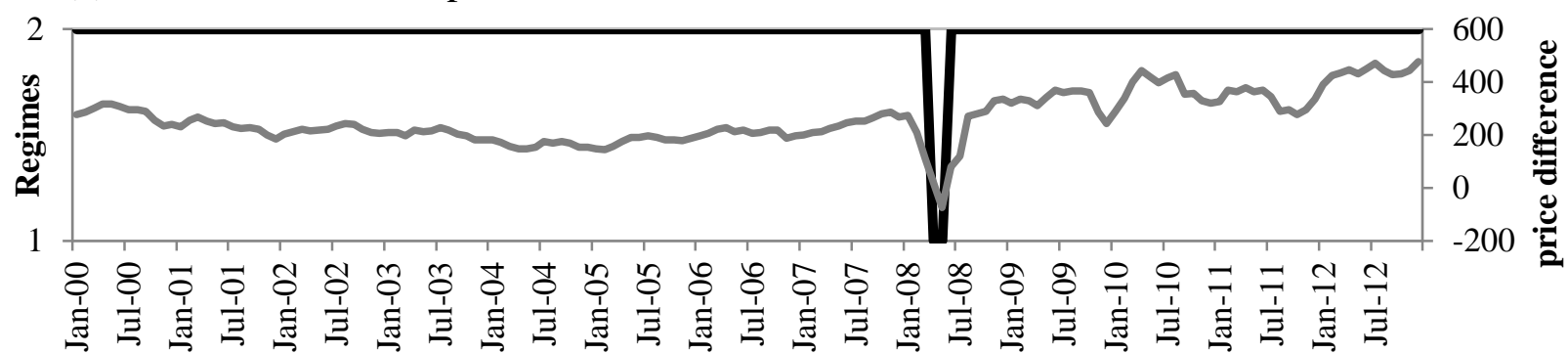

(b) Well-milled, Wholesale price

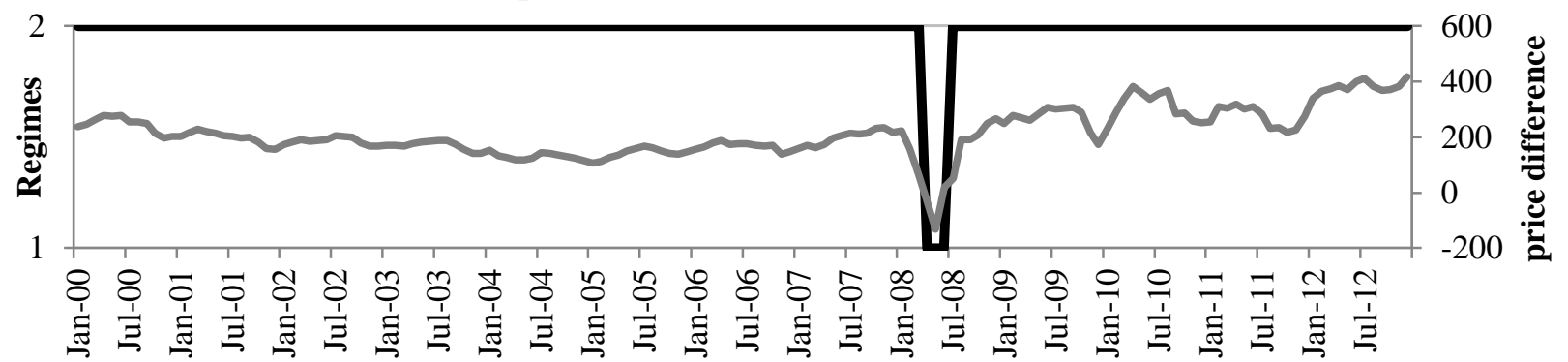

(c) Regular-milled, Retail price

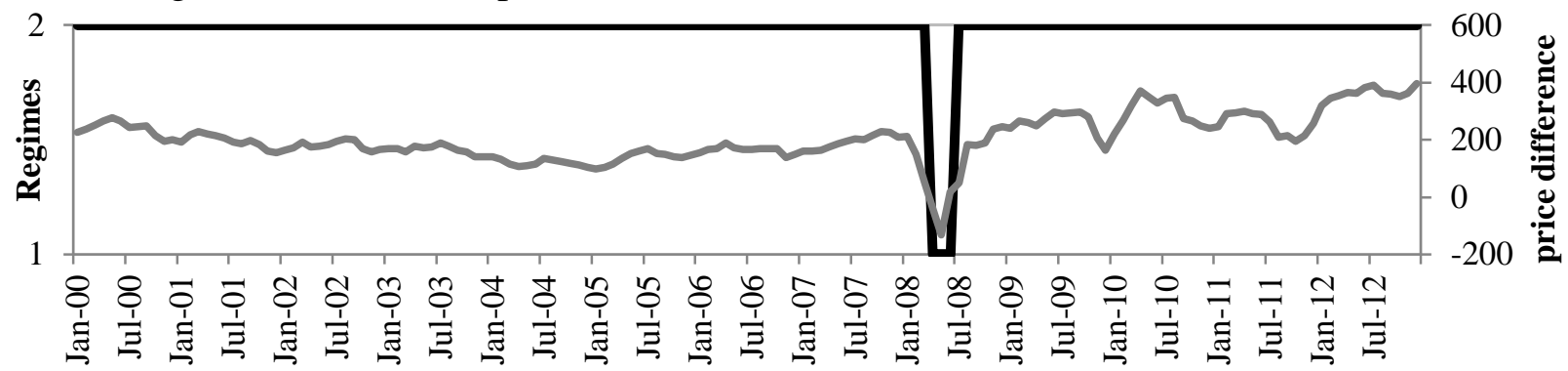

(d) Regular-milled, Wholesale price

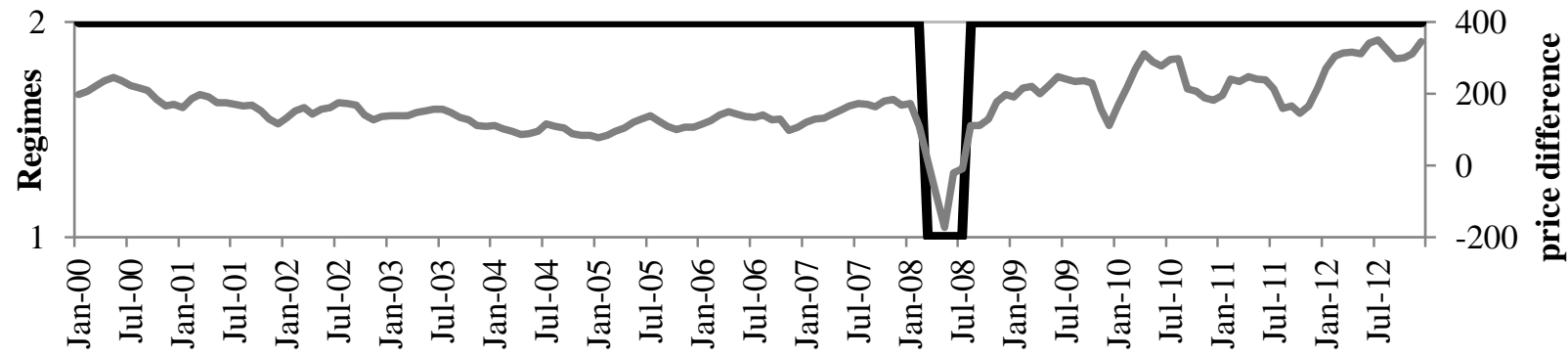


Figure 16. Thresholds and regime-switching, Philippines (national average, sample-split)

(a) Well-milled, Retail price

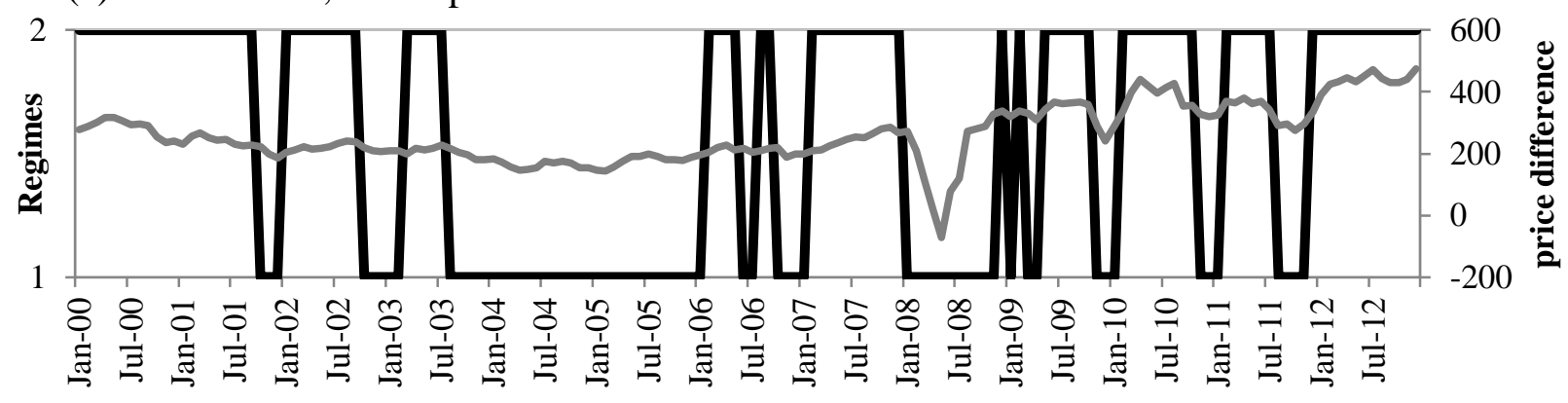

(b) Well-milled, Wholesale price



(c) Regular-milled, Retail price

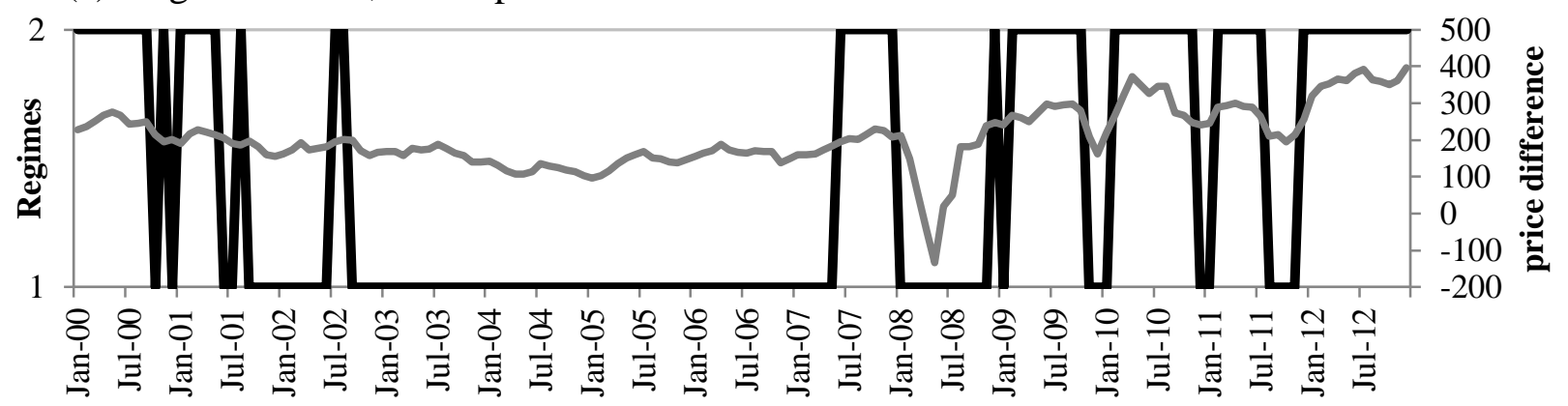

(d) Regular-milled, Wholesale price

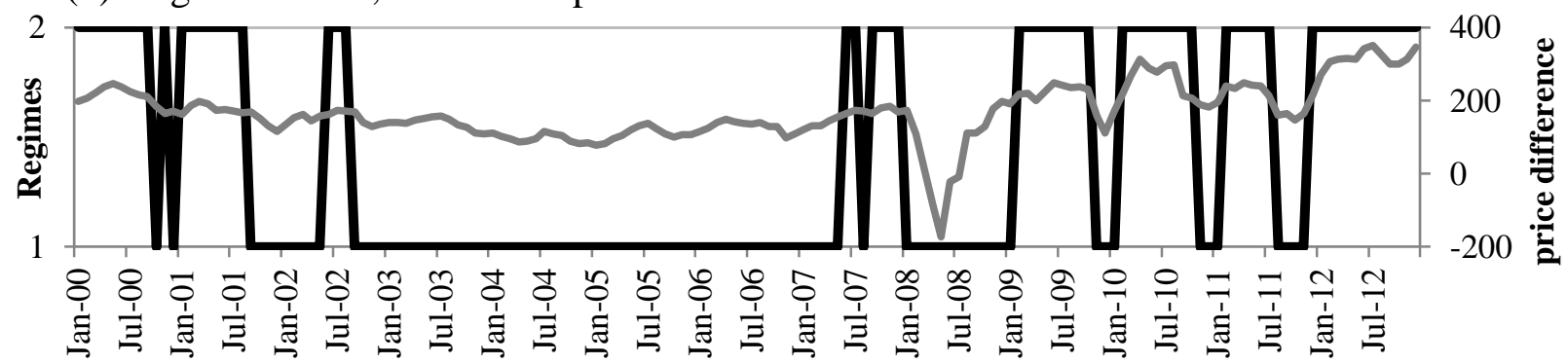

Notes: Pre-sample period=Jan 2000 to Dec 2007. Post-sample period=Jan 2008 to Dec 2012. 
Average threshold estimates increased from US $\$ 182$ ton $^{-1}$ pre- to US $\$ 239$ ton $^{-1}$ postDecember 2007, while the speed of adjustment decreased from 0.396 to 0.161 in the same period. Thresholds are larger at the retail level and for well-milled rice. Moreover, the speed of adjustment is fastest in Metro Manila (the capital), in Nueva Ecija (the largest rice producing region), and in Cebu (major city in central Philippines). We confirm in most cases that the adjustment parameters are larger in magnitude in regime 1 than in regime 2 in the post-December 2007 period. This suggests that PT is restricted when the price difference exceeds the threshold.

We examine the volatility of price differences using the coefficient of variation $(\mathrm{CV})$, defined as the ratio of the standard deviation to the mean. Figure 17 shows CV estimates for pre- and post- sample periods and confirms excessive volatility in regime 1 post-sample period. This price volatility was a serious threat to food security in many rice-importing countries because it created unpredictability in the market for rice (WB, 2012). The problem was magnified for the Philippines since it was the biggest importer of rice in 2008. The unusual volatile months in regime 1 perhaps created opportunities for unlawful arbitrage and have contributed to the violation of spatial arbitrage theory, in which the adjustment parameters are larger in magnitude in regime 1 than in regime 2.

We convert our rice prices to domestic currency values (Philippine pesos) and find rice prices remaining almost constant across the board from 2009 to 2012 (figure 18), an indication of the government's price stabilization policy. While there appears to be numerous spatial arbitrage opportunities, especially since export prices have started a downward trend in 2012, PT from world to domestic markets in the Philippines have largely been restricted confirming our results from TVECM estimation. This is not surprising since the government through the National Food Authority (NFA) has import monopoly on rice. Import tariffs, sales tax, and import quotas are substantial costs in the price margin between world and domestic rice markets. In the Philippines, sales tax is $12 \%$ and import duty is $40 \%$ within the import quota of 350,000 tons (and 50\% above the quota). The contribution of other trade distortions, other than tariffs, can also be substantial. Cororaton (2006) estimates this to be more than $50 \%$ of the price of rice at border.

However, the country is far from removing non-tariff barriers in rice trade. The special treatment accorded to the Philippines for rice by the World Trade Organization exempted the product for tariffication. While the original agreement expired in June 2012, the government requested for an extension that will expire in June 2015. Now, the government is requesting for yet another extension on the special clause on rice (Briones, 2012). The special treatment allows non-tariff restrictions on rice trade; thus, the end of the agreement compels the country to convert all non-tariff barriers, particularly quantitative restrictions, to custom duties. Future studies on market integration and PT in the Philippines could assess the impact of tariffication in world to domestic price relationships. 
Figure 17. Price difference volatility (national average, sample-split)
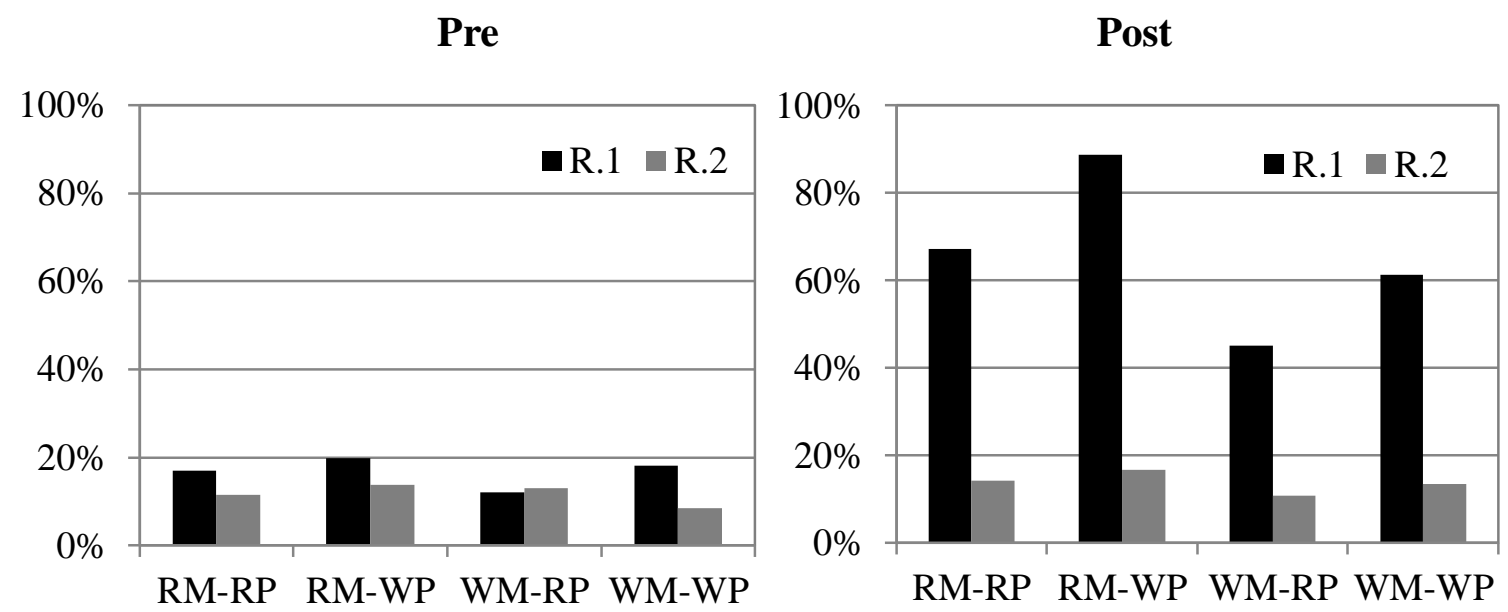

Notes: Price difference volatility is defined as the ratio of the standard deviation of price difference with V25 to the mean price difference with V25.Pre-sample period=Jan 2000 to Dec 2007. Post-sample period=Jan 2008 to Dec 2012. $\mathrm{RM}=$ regular-milled rice; $\mathrm{WM}=$ well-milled rice; $\mathrm{RP}=$ retail price; $\mathrm{WP}=$ wholesale price

Figure 18. Domestic rice prices in the Philippines (Php kilo $\left.{ }^{-1}\right)$, Jan 2006 to Dec 2012

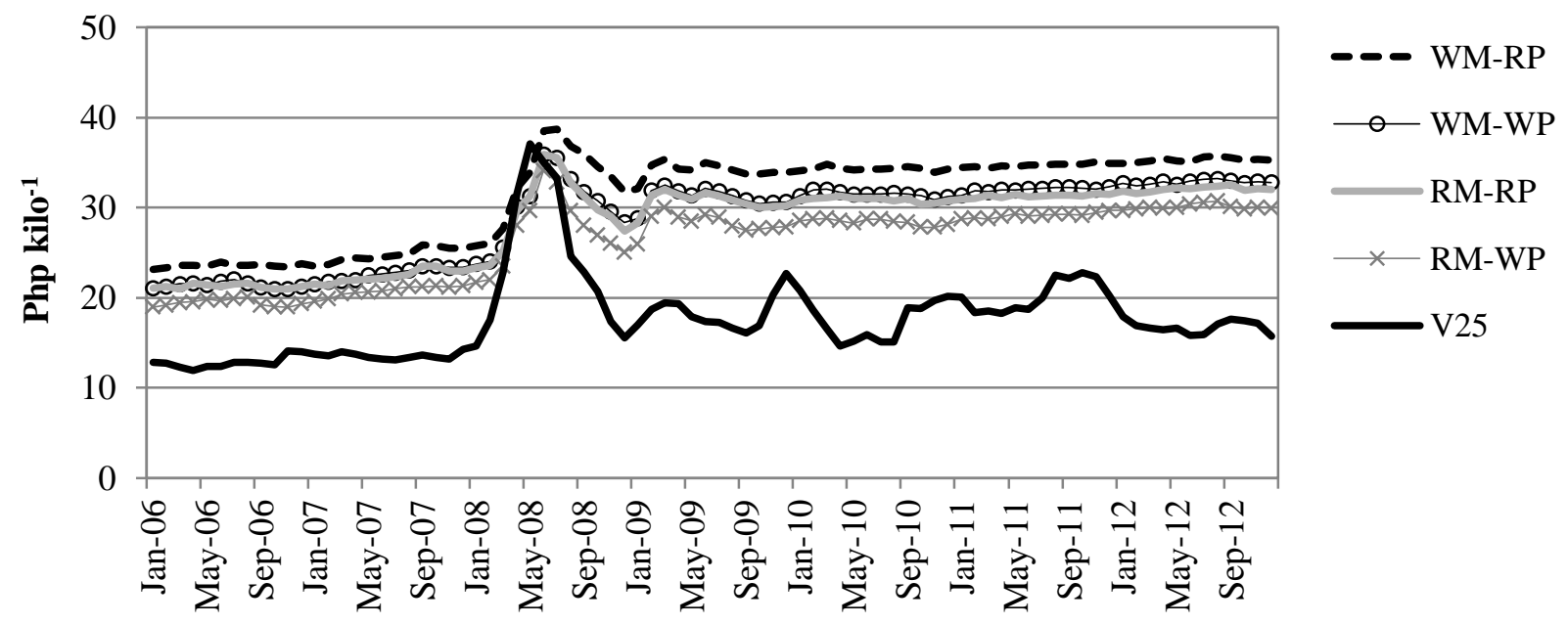

Notes: V25=Vietnam $25 \%$ brokens; $\mathrm{RM}=$ regular-milled rice; $\mathrm{WM}=$ =ell-milled rice; $\mathrm{RP}=$ retail price; $\mathrm{WP}=$ wholesale price. $\mathrm{Php}=$ Philippine pesos. Source of raw data: FAO-GIEWS.

\section{Concluding remarks}

For many developing countries, changes in rice prices have considerable effects on both the purchasing power of the poor and the welfare of small-holder farmers. The study aims to improve our understanding of the extent and speed of the transmission of international rice prices to domestic markets in developing countries in the light of the 2008 food crisis. Information on these price dynamics will help better estimate the welfare impacts of policy interventions that influence market integration and PT. 
The first paper finds Vietnam export prices to be cointegrated with the largest number of domestic markets. In the second paper, we show two major changes in the dynamics of world to domestic price relations before and after the 2008 food crisis. First, thresholds, or the price differences between world and domestic rice markets, have increased. Second, the speed of price adjustment in most countries has declined post-food crisis. Although many factors can cause slow price adjustment, such as high TC, the two findings, together, imply a slower PT in the period of wider price margins for countries that implemented certain policies during the 2008 food price crisis. Such interventions had an impact on price transmission dynamics in the world to domestic rice markets and had contributed to further price escalation.

For a politically-sensitive commodity such as rice, the large thresholds in many developing countries do not only harm consumers but create opportunities for rent-seeking and unlawful arbitrage. ${ }^{21}$ Because rice prices are higher in importing countries, expanding rice imports could reduce price margins and enhance market integration. However, this has both positive and negative effects. Higher thresholds indicate higher trade costs and prevalent trade distortions. Lower thresholds, i.e., domestic prices decline relative to world prices, could hurt many small farmers in developing countries if this occurs rapidly and safety nets are not in place (Dawe et al., 2006). In this scenario, producer-oriented policy measures, and maybe targeted income support, can serve as incentive for farmers to increase yields or diversify agricultural livelihoods. Agricultural investments can boost domestic food supply and reinforce the resilience of local rice markets to global price shocks (Rapsomanikis, 2011), Yet, for countries with government monopoly on imports, expanding imports come at a cost. A first step to help improve market integration in rice markets could be defining and quantifying trade costs in all levels and for all stakeholders. This may involve broader market information and sharing (Clarete, Adriano, \& Esteban, 2013) and the standardization of rice quality and grades across countries. There is also scope to reduce trade costs due to geography and distance by improving transport infrastructure within and across regions

We acknowledge several limitations of this study. First, we are compelled to use parsimonious model specifications for both the VECM and TVECM that can be automated for the analysis of a large number of price pairs. Second, the use of Vietnam $25 \%$ brokens in empirical estimations may not be the best choice for each domestic price series that we analyze. Third, the use of bivariate models in assessing market integration between domestic and world rice markets may not be appropriate considering that countries import rice of different types and from different sources. Future work may estimate multivariate VECMs (e.g., including multiple export prices) and compare results for different lag lengths and for different export prices. Finally, the use of higher frequency data disaggregated by rice quality could shed better information in PT dynamics. We acknowledge that current price information and trade statistics are limited, particularly in developing countries. For example, the Philippines only started to monitor and publish weekly retail price series of basic commodities in 2008 during the food price peak. Yet, there is now an initiative by the FAO, WB and the UN (2012) to improve agricultural and rural statistics globally and this opens huge prospects for better commodity analysis. The inclusion of price transmission estimates in a broader computable general equilibrium model (e.g., Siddig and Grethe, 2014) could also advance our understanding of economic wide impacts of food price shocks.

21 "High-ranking officials involved in P56-B rice smuggling - Customs report" (Marcelo, 2014) 
7. Annex 


\begin{tabular}{|c|c|c|}
\hline Year & Authors & Title \\
\hline 2013 & Benson et al. & $\begin{array}{l}\text { Information to guide policy responses to higher global food prices: The data and } \\
\text { analyses required }\end{array}$ \\
\hline 2013 & Baltzer & $\begin{array}{l}\text { International to domestic price transmission in fourteen developing countries during } \\
\text { the } 2007-08 \text { food crisis }\end{array}$ \\
\hline 2012 & Ianchovichina et al. & How vulnerable are Arab countries to global food price shocks? \\
\hline 2012 & Martin \& Anderson & Export Restrictions and Price Insulation During Commodity Price Booms \\
\hline 2012 & Von Braun \& Tadesse & Global Food Price Volatility and Spikes: An Overview of Costs, Causes, and Solutions \\
\hline 2011 & $\begin{array}{l}\text { Abott \& Borot de } \\
\text { Battisti }\end{array}$ & $\begin{array}{l}\text { Recent Global Food Price Shocks: Causes, Consequences and Lessons for African } \\
\text { Governments and Donors }\end{array}$ \\
\hline 2011 & Durant-Morat \& Wailes & Rice Trade Policies and Their Implications for Food Security \\
\hline 2011 & Edward Yu et al. & $\begin{array}{l}\text { A quantitative analysis of trade policy responses to higher world agricultural } \\
\text { commodity prices }\end{array}$ \\
\hline 2011 & FAO & How does international price volatility affect domestic economies and food security? \\
\hline 2011 & FAO \& OECD & Price Volatility in Food and Agricultural Markets: Policy Responses \\
\hline 2011 & G20 & Action plan on food price volatility and agriculture \\
\hline 2011 & Headey & Rethinking the global food crisis: The role of trade shocks \\
\hline 2011 & Robles & $\begin{array}{l}\text { Price transmission from international agricultural commodity markets to domestic food } \\
\text { prices: Case studies in Asia and Latin America }\end{array}$ \\
\hline 2011 & Sarris et al. & $\begin{array}{l}\text { The use of organized commodity markets to manage food import price instability and } \\
\text { risk }\end{array}$ \\
\hline 2010 & Asia Society \& IRRI & Never an Empty Bowl: Sustaining Food Security in Asia \\
\hline 2010 & Dawe & The Rice Crisis: Markets, Policies and Food Security \\
\hline 2010 & FAO & $\begin{array}{l}\text { Addressing Food Insecurity in Protracted Crises. The State of Food Insecurity in the } \\
\text { World }\end{array}$ \\
\hline 2010 & Gilbert & How to understand high food prices \\
\hline 2010 & Headey \& Fan & $\begin{array}{l}\text { Reflections on the Global Food Crisis How Did It Happen? How Has It Hurt? And } \\
\text { How Can We Prevent the Next One? }\end{array}$ \\
\hline 2010 & Headey et al. & Navigating the perfect storm: reflections on the food, energy, and financial crises \\
\hline 2010 & Keats et al. & Food price transmission: rising international cereals prices and domestic markets \\
\hline 2010 & Minot & $\begin{array}{l}\text { Transmission of world food price changes to African markets and its effect on } \\
\text { household welfare }\end{array}$ \\
\hline 2010 & Mondi et al. & Oil shocks and the world rice market puzzle: a structural VAR analysis \\
\hline 2010 & Seck et al. & $\begin{array}{l}\text { Rising trends and variability of rice prices: threats and opportunities for sub-Saharan } \\
\text { Africa }\end{array}$ \\
\hline 2010 & Timmer & Reflections on food crises past \\
\hline 2010 & Timmer & The Changing Role of Rice in Asia's Food Security \\
\hline 2009 & Dawe & The Unimportance of "Low" World Grain Stocks for Recent World Price Increases \\
\hline 2009 & Lustig & Coping with Rising Food Prices: Policy Dilemmas in the Developing World \\
\hline 2009 & McCalla & World Food Prices: Causes and Consequences \\
\hline 2009 & Piesse \& Thirtle & $\begin{array}{l}\text { Three bubbles and a panic: an explanatory review of recent food commodity price } \\
\text { events }\end{array}$ \\
\hline 2009 & Slayton & $\begin{array}{l}\text { Rice Crisis Forensics: How Asian Governments Carelessly Set the World Rice Market } \\
\text { on Fire }\end{array}$ \\
\hline 2008 & ADB & Soaring Food Prices: Response to the Crisis \\
\hline 2008 & Benson et al. & Global Food Crises: Monitoring and Assessing Impact to Inform Policy Responses \\
\hline 2008 & Dawe & $\begin{array}{l}\text { Have recent increases in international cereal prices been transmitted to domestic } \\
\text { economies? The experience in seven large Asian countries }\end{array}$ \\
\hline 2008 & Demeke et al. & $\begin{array}{l}\text { Country responses to the food security crisis: Nature and preliminary implications of } \\
\text { the policies pursued }\end{array}$ \\
\hline 2008 & Dewbre et al. & High food commodity prices: Will they stay? Who will pay? \\
\hline 2008 & FAO & High food prices and food security - threats and opportunities \\
\hline 2008 & Headey \& Fan & Anatomy of a crisis: the causes and consequences of surging food prices \\
\hline 2008 & IRRI & Responding to the rice crisis: how IRRI can work with its partners \\
\hline 2008 & Ivanic \& Martin & Implications of higher global food prices for poverty in low-income countries \\
\hline 2008 & Sachs & Surging Food Prices Mean Global Instability \\
\hline 2008 & Slayton \& Timmer & Japan, China and Thailand Can Solve the Rice Crisis - But U.S. Leadership Is Needed \\
\hline 2008 & Trostle & $\begin{array}{l}\text { Global Agricultural Supply and Demand: Factors Contributing to the Recent Increase } \\
\text { in Food Commodity Prices }\end{array}$ \\
\hline 2008 & von Braun & Responding to the World Food Crisis: Getting on the Right Track \\
\hline 2008 & von Braun & The food crisis isn't over \\
\hline 2008 & World Bank & Rising Food Prices: Policy Options and World Bank Response \\
\hline
\end{tabular}


Annex 2. Country-level studies on rice price analysis, post-2008

\begin{tabular}{|c|c|c|c|}
\hline Country & Year & Author & Title \\
\hline \multicolumn{4}{|l|}{ Southeast Asia } \\
\hline Thailand & 2012 & Chulaphan et al. & Causal impact price transmission of the rice markets in Thailand \\
\hline Vietnam & 2012 & Coxhead et al. & Global market shocks and poverty in Vietnam: the case of rice \\
\hline Indonesia & 2012 & Varela et al. & Determinants of Market Integration and Price Transmission in Indonesia \\
\hline Philippines & 2011 & Jolejole \& Mallory & $\begin{array}{l}\text { Analyzing Market Price Transmission, Government Intervention and Weather } \\
\text { Shocks for Rice Market in the Philippines }\end{array}$ \\
\hline Philippines & 2011 & Rufino & Analyzing the Philippines Inter-Regional Market Integration for Rice \\
\hline Philippines & 2010 & Samson et al. & Spatial analysis of price transmission efficiencies in Philippine rice market \\
\hline Philippines & 2009 & Reyes et al. & $\begin{array}{l}\text { Analysis of the impact of changes in the prices of rice and fuel on poverty in the } \\
\text { Philippines }\end{array}$ \\
\hline Vietnam & 2008 & Baulch et al. & The spatial integration of paddy markets in Vietnam \\
\hline Indonesia & 2008 & Dawe & Can Indonesia trust the world rice market? \\
\hline Thailand, Vietnam & 2008 & Ghoshray & $\begin{array}{l}\text { Asymmetric Adjustment of Rice Export Prices: The Case of Thailand and } \\
\text { Vietnam }\end{array}$ \\
\hline Indonesia & 2008 & Marks & Unity or diversity? Market integration and long-run economic growth in Indonesia \\
\hline Philippines & 2008 & Matriz & Price transmission mechanism in the Philippine rice industry \\
\hline Indonesia & 2008 & Warr & The transmission of import prices to domestic prices: an application to Indonesia \\
\hline Myanmar & 2007 & Myint & Myanmar rice market: market integration and price causality \\
\hline Vietnam & 2007 & Trung et al. & Testing for food market integration: a study of the Vietnamese paddy market \\
\hline \multicolumn{4}{|l|}{ South Asia } \\
\hline India & 2012 & Acharya et al. & $\begin{array}{l}\text { Market integration and price transmission in India: A case of rice and wheat with } \\
\text { special reference to the world food crisis of } 2007 / 08\end{array}$ \\
\hline Bangladesh & 2012 & Alam et al. & $\begin{array}{l}\text { Measuring Market Integration in the Presence of Threshold Effect: The Case of } \\
\text { Bangladesh Rice Markets }\end{array}$ \\
\hline Pakistan & 2012 & Ghafoor \& Islam & Market integration and price transmission in rice markets of Pakistan \\
\hline India & 2011 & Ghosh & Agricultural policy reforms and spatial integration of food grain markets in India \\
\hline Bangladesh & 2010 & Alam et al. & $\begin{array}{l}\text { Testing asymmetric price transmission in the vertical supply chain in deregulated } \\
\text { rice markets in Bangladesh }\end{array}$ \\
\hline Iran & 2010 & Bakhshoodeh & Impacts of world prices transmission to domestic rice markets in rural Iran \\
\hline India & 2010 & Ghosh & Spatial price linkages in regional food grain markets in India \\
\hline Bangladesh & 2010 & Hossain \& Verbeke & Evaluation of rice markets integration in Bangladesh \\
\hline Nepal & 2010 & Sanogo \& Amadou & $\begin{array}{l}\text { Rice market integration and food security in Nepal: The role of cross-border trade } \\
\text { with India }\end{array}$ \\
\hline Bangladesh & 2008 & Ashraf & $\begin{array}{l}\text { Econometric analysis of the impact of domestic rice procurement policy on } \\
\text { producer price: the case of rice in Bangladesh }\end{array}$ \\
\hline India & 2008 & Imai et al. & $\begin{array}{l}\text { Transmission of world commodity prices to domestic commodity prices in India } \\
\text { and China }\end{array}$ \\
\hline Nepal & 2008 & Sanogo & $\begin{array}{l}\text { Spatial integration of the rice market: empirical evidence from mid-west and far- } \\
\text { west Nepal, and the Nepalese-Indian border }\end{array}$ \\
\hline India & 2007 & Jayasuriya et al. & $\begin{array}{l}\text { International and internal market integration in Indian agriculture: a study of the } \\
\text { Indian rice market }\end{array}$ \\
\hline \multicolumn{4}{|l|}{ East Asia } \\
\hline China & 2011 & Chen et al. & Market integration in the People's Republic of China \\
\hline Taiwan & 2009 & Wang \& Lee & A measure of marketing price transmission in the rice market of Taiwan \\
\hline China & 2008 & Imai et al. & $\begin{array}{l}\text { Transmission of world commodity prices to domestic commodity prices in India } \\
\text { and China }\end{array}$ \\
\hline \multicolumn{4}{|l|}{ Africa } \\
\hline Benin, Mali & 2013 & Fiamohe et al. & $\begin{array}{l}\text { Price transmission analysis using threshold models: an application to local rice } \\
\text { markets in Benin and Mali }\end{array}$ \\
\hline Multiple countries & 2012 & Greb et al. & Cereal price transmission from international to domestic markets in Africa \\
\hline Nigeria & 2011 & Ohen \& Abang & $\begin{array}{l}\text { Evaluation of price linkages within the supply chain of rice markets in Cross River } \\
\text { State, Nigeria }\end{array}$ \\
\hline Madagascar & 2010 & Butler \& Moser & Structural model of agricultural markets in developing countries \\
\hline Multiple countries & 2010 & Minot & $\begin{array}{l}\text { Transmission of world food price changes to African markets and its effect on } \\
\text { household welfare }\end{array}$ \\
\hline Madagascar & 2009 & Moser et al. & Spatial integration at multiple scales: rice markets in Madagascar \\
\hline Ghana & 2008 & Cudjoe et al. & $\begin{array}{l}\text { Local impacts of a global crisis: food price transmission and poverty impacts in } \\
\text { Ghana }\end{array}$ \\
\hline Mali, Nicaragua & 2011 & Baquedano et al. & $\begin{array}{l}\text { World market integration for export and food crops in developing countries: a case } \\
\text { study for Mali and Nicaragua }\end{array}$ \\
\hline \multicolumn{4}{|l|}{ Latin America } \\
\hline Bolivia & 2012 & Varela & $\begin{array}{l}\text { Incomplete, Slow, and Asymmetric Price Transmission in Ten Product Markets of } \\
\text { Bolivia }\end{array}$ \\
\hline Bolivia & 2011 & Schuttel et al. & Domestic policy responses to the food price crisis: the case of Bolivia \\
\hline Brazil & 2011 & $\begin{array}{l}\text { Hernandez- } \\
\text { Villafuerte }\end{array}$ & $\begin{array}{l}\text { Relationship between spatial price transmission and geographical distance in } \\
\text { Brazil }\end{array}$ \\
\hline Multiple countries & 2011 & Robles & $\begin{array}{l}\text { Price transmission from international agricultural commodity markets to domestic } \\
\text { food prices: Case studies in Asia and Latin America }\end{array}$ \\
\hline Peru & 2009 & Dawe \& Maltsoglou & $\begin{array}{l}\text { Analyzing the impact of food price increases: assumptions about marketing } \\
\text { margins can be crucial }\end{array}$ \\
\hline
\end{tabular}


Annex 3. TVECM estimates, all markets

\begin{tabular}{|c|c|c|c|c|c|c|c|c|c|c|c|c|c|c|c|}
\hline Domestic price & & & ll sa & & & & & Pr & & & & & Po & & \\
\hline Country-market-quality-level & rank & seo & $\tau$ & R.1 & R.2 & rank & seo & $\tau$ & R.1 & R.2 & rank & seo & $\tau$ & R.1 & R.2 \\
\hline Philippines - Cebu - regular milled - retail & 1 & 1 & 15 & 1.335 & 0.030 & 0 & 0 & 250 & 0.053 & 0.983 & & 1 & 283 & 0.259 & 0.250 \\
\hline Philippines - Cebu - regular milled - wholesale & 1 & 1 & 29 & 1.195 & 0.059 & 0 & 0 & 196 & 0.016 & 0.471 & . & 1 & 244 & 0.315 & 0.257 \\
\hline Philippines - Cebu - well milled - retail & 1 & 1 & 55 & 1.310 & 0.057 & 0 & 0 & 290 & 0.013 & 0.345 & . & 1 & 360 & 0.276 & 0.263 \\
\hline Philippines - Cebu - well milled - wholesale & 1 & 1 & 25 & 1.295 & 0.040 & 0 & 0 & 241 & 0.030 & 0.582 & . & 1 & 310 & 0.268 & 0.268 \\
\hline Philippines - Davao City - regular milled - retail & 0 & 0 & 31 & 1.700 & 0.037 & 0 & 0 & 139 & 0.023 & 0.022 & 1 & 1 & 210 & 0.196 & 0.082 \\
\hline Philippines - Davao City - regular milled - wholesale & 1 & 1 & 35 & 1.378 & 0.035 & 0 & 0 & 194 & 0.039 & 0.897 & 1 & 1 & 109 & 0.000 & 0.039 \\
\hline Philippines - Davao City - well milled - retail & 1 & 1 & 15 & 2.603 & 0.018 & 0 & 0 & 167 & 0.057 & 0.032 & 1 & 1 & 340 & 0.130 & 0.142 \\
\hline Philippines - Davao City - well milled - wholesale & 1 & 1 & 75 & 1.527 & 0.041 & 0 & 0 & 253 & 0.027 & 6.024 & 1 & 1 & 230 & 0.039 & 0.075 \\
\hline Philippines - Iloilo - regular milled - retail & 1 & 0 & 29 & 1.174 & 0.026 & 0 & 0 & 173 & 0.072 & 0.072 & . & 0 & 365 & 0.253 & 0.207 \\
\hline Philippines - Iloilo - regular milled - wholesale & 1 & 1 & 1 & 0.613 & 0.018 & 0 & 0 & 95 & 0.104 & 0.104 & 1 & 1 & 12 & 0.020 & 0.020 \\
\hline Philippines - Iloilo - well milled - retail & 1 & 1 & 145 & 1.387 & 0.038 & 0 & 0 & 238 & 0.049 & 0.049 & . & 1 & 475 & 0.240 & 0.216 \\
\hline Philippines - Iloilo - well milled - wholesale & 1 & 1 & 41 & 0.674 & 0.039 & 1 & 0 & 98 & 0.084 & 0.074 & 1 & 1 & 170 & 0.175 & 0.086 \\
\hline Philippines - Metro Manila - regular milled - retail & 1 & 1 & 15 & 1.135 & 0.034 & 0 & 0 & 126 & 0.037 & 0.026 & & 1 & 287 & 0.325 & 0.292 \\
\hline Philippines - Metro Manila - regular milled - wholesale & 0 & 1 & 1 & 2.039 & 0.015 & 0 & 0 & 171 & 0.113 & 0.106 & 1 & 0 & 158 & 0.156 & 0.161 \\
\hline Philippines - Metro Manila - well milled - retail & 1 & 0 & 135 & 0.614 & 0.053 & 0 & 0 & 290 & 0.039 & 0.689 & . & 1 & 377 & 0.257 & 0.257 \\
\hline Philippines - Metro Manila - well milled - wholesale & 1 & 1 & 15 & 1.139 & 0.033 & 1 & 0 & 199 & 0.064 & 0.064 & . & 1 & 270 & 0.310 & 0.276 \\
\hline Philippines - National Average - regular milled - retail & 1 & 0 & 19 & 1.269 & 0.033 & 0 & 0 & 195 & 0.022 & 0.047 & 1 & 0 & 245 & 0.173 & 0.123 \\
\hline Philippines - National Average - regular milled - wholesale & 0 & 0 & 15 & 1.200 & 0.027 & 0 & 0 & 165 & 0.015 & 0.046 & 1 & 1 & 197 & 0.200 & 0.152 \\
\hline Philippines - National Average - well milled - retail & 1 & 0 & 15 & 1.728 & 0.022 & 0 & 0 & 210 & 0.040 & 0.041 & 1 & 0 & 330 & 0.200 & 0.159 \\
\hline Philippines - National Average - well milled - wholesale & 1 & 0 & 19 & 1.294 & 0.033 & 0 & 0 & 228 & 0.032 & 0.063 & 1 & 0 & 260 & 0.170 & 0.136 \\
\hline Philippines - Nueva Ecija - regular milled - retail & 1 & 1 & 9 & 1.251 & 0.023 & 0 & 0 & 147 & 0.002 & 0.009 & . & 1 & 260 & 0.217 & 0.217 \\
\hline Philippines - Nueva Ecija - regular milled - wholesale & 1 & 1 & 60 & 0.603 & 0.062 & 0 & 0 & 157 & 0.080 & 0.080 & . & 1 & 160 & 0.181 & 0.177 \\
\hline Philippines - Nueva Ecija - well milled - retail & 1 & 1 & 75 & 0.980 & 0.067 & 0 & 0 & 226 & 0.046 & 0.046 & . & 1 & 353 & 0.278 & 0.271 \\
\hline Philippines - Nueva Ecija - well milled - wholesale & 1 & 1 & 94 & 0.600 & 0.058 & 0 & 0 & 181 & 0.058 & 0.058 & . & 1 & 274 & 0.226 & 0.226 \\
\hline Philippines - South Cotabato - regular milled - retail & 1 & 1 & 45 & 1.793 & 0.037 & 0 & 1 & 112 & 0.040 & 0.040 & . & 1 & 132 & 0.000 & 0.056 \\
\hline Philippines - South Cotabato - regular milled - wholesale & 1 & 1 & 1 & 0.723 & 0.016 & 1 & 0 & 97 & 0.044 & 0.044 & & 1 & 1 & 0.009 & 0.009 \\
\hline Philippines - South Cotabato - well milled - retail & 0 & 0 & 75 & 1.472 & 0.039 & 0 & 0 & 153 & 0.035 & 0.035 & 1 & 1 & 250 & 0.157 & 0.071 \\
\hline Philippines - South Cotabato - well milled - wholesale & 1 & 0 & 12 & 1.181 & 0.028 & 1 & 0 & 117 & 0.033 & 0.033 & & 1 & 21 & 0.000 & 0.021 \\
\hline Bangladesh - Dhaka - coarse - wholesale & 1 & 1 & 3 & 0.134 & 0.134 & 0 & 1 & 17 & 0.098 & 0.098 & 1 & 1 & 19 & 0.095 & 0.322 \\
\hline Bangladesh - National Average - coarse - wholesale & 1 & 0 & 5 & 0.134 & 0.134 & 0 & 1 & 4 & 0.144 & 0.050 & 1 & 1 & 13 & 0.112 & 0.112 \\
\hline Bangladesh - Dhaka - coarse - retail & . & 1 & 8 & 0.188 & 0.188 & 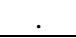 & 0 & 4 & 0.144 & 0.050 & . & 1 & 8 & 0.188 & 0.188 \\
\hline Bhutan - Samdrup Jongkhar - white - retail & . & 1 & 3 & 0.107 & 0.169 & . & 0 & 4 & 0.144 & 0.050 & . & 0 & 3 & 0.107 & 0.169 \\
\hline Bhutan - Trashigang - white - retail & 1 & 0 & 3 & 0.158 & 0.158 & . & 0 & 4 & 0.144 & 0.050 & 1 & 1 & 3 & 0.158 & 0.158 \\
\hline
\end{tabular}

Notes: Using Vietnam 25\% brokens as the international reference price. Pre=sample period from Jan 2000 to Dec 2007. Post=sample period from Jan 2008 to Dec 2012 . rank=1 if linearly cointegrated. seo=1 if threshold cointegrated. $\boldsymbol{\tau}=$ threshold. R.1=Regime 1 adjustment parameters from the sum of the elements in $\boldsymbol{\alpha}_{\mathbf{1}}$. R.2=Regime 2 adjustment parameters from the sum of the elements in $\boldsymbol{\alpha}_{2}$. "."=not calculated. Source of raw data: FAO-GIEWS. 
Annex 3 (continued). TVECM estimates, all markets

\begin{tabular}{|c|c|c|c|c|c|c|c|c|c|c|c|c|c|c|c|}
\hline Domestic price & & & ll $s$ & & & & & Pr & & & & & Po & & \\
\hline Country-market-quality-level & rank & seo & $\tau$ & R.1 & R.2 & rank & seo & $\tau$ & R.1 & R.2 & rank & seo & $\tau$ & R.1 & R.2 \\
\hline Indonesia - National Average - retail & 0 & 0 & $26 ?$ & 0.011 & 0.011 & 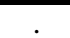 & 0 & 15 & 0.185 & 0.184 & 0 & 0 & 263 & 0.011 & 0.011 \\
\hline Indonesia - National Average - medium quality - retail & . & 0 & 382 & 0.301 & 0.286 & . & 0 & 15 & 0.185 & 0.184 & . & 0 & 382 & 0.301 & 0.286 \\
\hline Laos - Champasack - Glutinous first quality - retail & . & 0 & $27 ?$ & 0.068 & 0.068 & . & 0 & 15 & 0.185 & 0.184 & . & 0 & 277 & 0.068 & 0.068 \\
\hline Laos - Champasack - Glutinous second quality - retail & . & 0 & 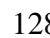 & 0.090 & 0.090 & . & 0 & 15 & 0.185 & 0.184 & . & 0 & 128 & 0.090 & 0.090 \\
\hline Laos - Khammouane - Glutinous first quality - retail & . & 1 & 32 & 0.361 & 0.035 & 0 & 0 & 155 & 0.017 & 0.030 & . & 0 & 102 & 0.050 & 0.050 \\
\hline Laos - Khammouane - Glutinous second quality - retail & . & 0 & 15 & 0.334 & 0.047 & 0 & 0 & 135 & 0.065 & 0.070 & . & 0 & 55 & 0.062 & 0.062 \\
\hline Laos - National Average - Glutinous first quality - retail & 1 & 1 & 5 & 0.422 & 0.015 & 0 & 0 & 5 & 0.034 & 0.034 & . & 0 & 111 & 0.054 & 0.056 \\
\hline Laos - National Average - Ordinary - retail & 1 & 1 & 15 & 1.388 & 0.011 & 0 & 0 & 87 & 0.014 & 0.033 & . & 0 & 430 & 0.160 & 0.157 \\
\hline Laos - Savannakhet - Glutinous first quality - retail & 0 & 0 & 10 & 0.202 & 0.020 & 0 & 0 & 78 & 0.000 & 0.016 & 1 & 0 & 26 & 0.271 & 0.017 \\
\hline Laos - Savannakhet - Glutinous second quality - retail & 1 & 0 & 13 & 0.194 & 0.034 & 0 & 0 & 68 & 0.046 & 0.060 & 1 & 0 & 13 & 0.026 & 0.026 \\
\hline Laos - Vientiane Capital - Ordinary first quality - retail & . & 1 & 215 & 0.844 & 0.034 & 0 & 0 & 249 & 0.209 & 0.151 & . & 1 & 595 & 0.131 & 0.131 \\
\hline Laos - Vientiane Capital - Glutinous second quality - retail & 1 & 1 & 42 & 0.261 & 0.035 & 0 & 0 & 88 & 0.133 & 0.133 & 1 & 1 & 159 & 0.000 & 0.031 \\
\hline Laos - Vientiane Capital - Glutinous first quality - retail & 1 & 1 & 55 & 0.464 & 0.023 & 0 & 0 & 150 & 0.161 & 0.136 & 1 & 0 & 277 & 0.000 & 0.035 \\
\hline Laos - Vientiane Capital - Ordinary second quality - retail & . & 0 & 65 & 0.800 & 0.029 & 0 & 0 & 137 & 0.158 & 0.160 & . & 1 & 443 & 0.131 & 0.131 \\
\hline Mongolia - Ulaanbaatar - retail & & 0 & 115 & 1.515 & 0.008 & 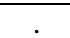 & 0 & & & & . & 0 & 457 & 0.050 & 0.029 \\
\hline Nepal - Kathmandu - coarse - retail & . & 1 & 12 & 0.321 & 0.174 & 0 & 1 & 7 & 0.100 & 0.100 & . & 1 & 9 & 0.151 & 0.151 \\
\hline Sri Lanka - Colombo - white - retail & . & 1 & 3 & 0.352 & 0.108 & 0 & 0 & 14 & 0.153 & 0.143 & . & 1 & 12 & 0.083 & 0.083 \\
\hline Timor-Leste - Maliana - local - retail & - & 1 & 398 & 0.254 & 0.327 & 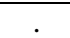 & 0 & 2 & 0.200 & 0.099 & . & 1 & 398 & 0.254 & 0.327 \\
\hline Benin - Abomey - imported - retail & 1 & 1 & 162 & 0.153 & 0.033 & 0 & 0 & 464 & 0.034 & 0.123 & 1 & 1 & 415 & 0.048 & 0.064 \\
\hline Benin - Cotonou - imported - retail & 1 & 1 & 212 & 0.087 & 0.046 & 0 & 0 & 212 & 0.017 & 0.018 & . & 1 & 642 & 0.202 & 0.205 \\
\hline Benin - Djougou - imported - retail & 1 & 1 & 15 & 0.000 & 0.048 & 1 & 1 & 213 & 0.031 & 0.031 & . & 1 & 475 & 0.170 & 0.144 \\
\hline Benin - Natitingou - imported - retail & 1 & 1 & $15^{7}$ & 0.185 & 0.031 & 1 & 0 & 492 & 0.025 & 0.379 & 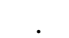 & 0 & 623 & 0.183 & 0.187 \\
\hline Burkina Faso - Bobo Dioulasso - imported - wholesale & 0 & 0 & 437 & 0.067 & 0.242 & . & 0 & 492 & 0.025 & 0.379 & 0 & 0 & 437 & 0.067 & 0.242 \\
\hline Burkina Faso - Dédougou - imported - wholesale & 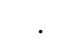 & 0 & 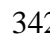 & 0.258 & 0.212 & & 0 & 492 & 0.025 & 0.379 & . & 0 & 342 & 0.258 & 0.212 \\
\hline Burkina Faso - Dori - imported - retail & 0 & 0 & 167 & 0.550 & 0.094 & 0 & 0 & 365 & 0.062 & 0.231 & 1 & 1 & 510 & 0.277 & 0.287 \\
\hline Burkina Faso - Dori - imported - wholesale & . & 1 & 199 & 1.023 & 0.074 & 0 & 0 & 307 & 0.103 & 0.903 & . & 1 & 415 & 0.183 & 0.183 \\
\hline Burkina Faso - Fada N'gourma - imported - wholesale & . & 1 & 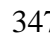 & 0.289 & 0.270 & . & 0 & 307 & 0.103 & 0.903 & • & 1 & 347 & 0.289 & 0.270 \\
\hline Burkina Faso - Kongoussi - imported - wholesale & . & 1 & 380 & 0.279 & 0.279 & . & 0 & 307 & 0.103 & 0.903 & . & 1 & 386 & 0.279 & 0.279 \\
\hline Burkina Faso - Nouna - imported - wholesale & . & 0 & 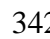 & 0.255 & 0.205 & . & 0 & 307 & 0.103 & 0.903 & 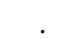 & 1 & 342 & 0.255 & 0.205 \\
\hline Burkina Faso - Ouagadougou - imported - wholesale & 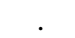 & 0 & 131 & 1.751 & 0.074 & 0 & 0 & 221 & 0.000 & 1.007 & . & 1 & 318 & 0.264 & 0.244 \\
\hline Burkina Faso - Tenkodogo - imported - wholesale & . & 0 & 426 & 0.241 & 0.244 & . & 0 & 221 & 0.000 & 1.007 & . & 0 & 426 & 0.241 & 0.244 \\
\hline Burundi - Bujumbura - retail & 1 & 1 & 10 & 0.000 & 0.017 & 0 & 0 & 481 & 0.257 & 0.257 & . & 1 & 595 & 0.000 & 0.009 \\
\hline Cameroon - Bafoussam - retail & . & 0 & 75 & 0.090 & 0.035 & 0 & 0 & 270 & 0.095 & 0.095 & . & 1 & 382 & 0.203 & 0.201 \\
\hline Cameroon - Bamenda - retail & 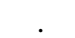 & 1 & 215 & 0.907 & 0.124 & 1 & 1 & 360 & 0.104 & 0.264 & . & 1 & 347 & 0.250 & 0.225 \\
\hline Cameroon - Douala - retail & 1 & 1 & 85 & 0.821 & 0.081 & 0 & 0 & 325 & 0.129 & 0.129 & . & 1 & 337 & 0.286 & 0.253 \\
\hline Cameroon - Garoua - retail & 1 & 1 & 20 & 0.204 & 0.067 & 0 & 1 & 428 & 0.174 & 0.167 & . & 1 & 501 & 0.200 & 0.199 \\
\hline Cameroon - Yaundé - retail & 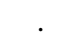 & 1 & 115 & 0.886 & 0.057 & 0 & 1 & 361 & 0.058 & 0.058 & . & 1 & 492 & 0.259 & 0.245 \\
\hline
\end{tabular}


Annex 3 (continued). TVECM estimates, all markets

\begin{tabular}{|c|c|c|c|c|c|c|c|c|c|c|c|c|c|c|c|}
\hline \multirow{2}{*}{$\begin{array}{l}\text { Domestic price } \\
\text { Country-market-quality-level }\end{array}$} & \multicolumn{5}{|c|}{ All sample } & \multicolumn{5}{|c|}{ Pre } & \multicolumn{5}{|c|}{ Post } \\
\hline & rank & seo & $\tau$ & R.1 & R.2 & rank & seo & $\tau$ & R.1 & R.2 & rank & seo & $\tau$ & R.1 & R.2 \\
\hline Cape Verde - S.Antão - long grain imported - retail & & 1 & 860 & 0.065 & 0.214 & 0 & 0 & 445 & 0.462 & 0.428 & . & 1 & 860 & 0.161 & 0.266 \\
\hline Cape Verde - S.Antão - short grain imported - retail & 1 & 1 & 813 & 0.076 & 0.364 & 0 & 0 & 360 & 0.118 & 1.170 & . & 1 & 813 & 0.144 & 0.377 \\
\hline Cape Verde - S.Vincente - long grain imported - retail & 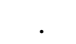 & 1 & 300 & 0.920 & 0.052 & 0 & 0 & 524 & 0.114 & 0.344 & . & 1 & 580 & 0.107 & 0.117 \\
\hline Cape Verde - S.Vincente - short grain imported - retail & 1 & 0 & 45 & 1.664 & 0.020 & 0 & 0 & 230 & 0.303 & 0.231 & . & 0 & 457 & 0.079 & 0.079 \\
\hline Cape Verde - Santiago - long grain imported - retail & 1 & 1 & 265 & 0.750 & 0.018 & 0 & 0 & 450 & 0.176 & 0.153 & 1 & 1 & 723 & 0.123 & 0.123 \\
\hline Cape Verde - Santiago - short grain imported - retail & 0 & 1 & 19 & 0.631 & 0.015 & 0 & 0 & 290 & 0.000 & 0.688 & 1 & 1 & 446 & 0.085 & 0.085 \\
\hline Chad - Moussoro - imported - retail & 1 & 1 & 670 & 0.258 & 0.223 & 0 & 0 & 684 & 0.295 & 0.388 & . & 1 & 845 & 0.331 & 0.331 \\
\hline Chad - N'Djamena - imported - retail & . & 0 & 728 & 0.195 & 0.338 & 1 & 0 & 573 & 0.021 & 0.312 & . & 0 & 717 & 0.216 & 0.321 \\
\hline Chad - N'Djamena - local - retail & . & 0 & 267 & 0.366 & 0.172 & 0 & 0 & 503 & 0.157 & 0.589 & . & 0 & 191 & 0.073 & 0.073 \\
\hline DR Congo - Bunia - local - retail & . & 1 & 541 & 0.145 & 0.145 & & 0 & 503 & 0.157 & 0.589 & ${ }^{\circ}$ & 1 & 549 & 0.119 & 0.119 \\
\hline DR Congo - Kinshasa - imported - retail & . & 1 & 505 & 0.304 & 0.144 & 1 & 0 & . & 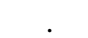 & . & . & 1 & 710 & 0.292 & 0.284 \\
\hline DR Congo - Kisangani - local - retail & . & 1 & 17 & 0.135 & 0.042 & 0 & 0 & . & . & . & . & 1 & 189 & 0.072 & 0.068 \\
\hline DR Congo - Lubumbashi - local - retail & . & 0 & 463 & 0.058 & 0.058 & & 0 & & & 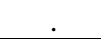 & . & 0 & 463 & 0.058 & 0.058 \\
\hline Djibouti - Djibouti - American - wholesale & 1 & 1 & 233 & 0.514 & 0.039 & 0 & 0 & 398 & 0.086 & 0.080 & . & 1 & 678 & 0.274 & 0.245 \\
\hline Djibouti - Djibouti - basmati - wholesale & 1 & 1 & 314 & 0.160 & 0.046 & 0 & 0 & 419 & 0.118 & 0.150 & . & 1 & 845 & 0.227 & 0.227 \\
\hline Djibouti - Djibouti - Belem - wholesale & 1 & 1 & 78 & 0.901 & 0.101 & 0 & 0 & 183 & 0.090 & 0.177 & 1 & 1 & 183 & 0.145 & 0.145 \\
\hline Gabon - Libreville - retail & & 1 & 490 & 0.565 & 0.161 & 0 & 0 & & & & & 1 & 672 & 0.324 & 0.305 \\
\hline Ghana - Accra - imported - retail & 0 & 0 & 472 & 0.000 & 0.030 & 0 & 0 & 472 & 0.011 & 0.055 & 0 & 0 & 630 & 0.371 & 0.371 \\
\hline Ghana - Accra - imported - wholesale & 0 & 1 & 425 & 0.223 & 0.014 & 0 & 0 & 540 & 0.079 & 0.082 & 0 & 1 & 490 & 0.416 & 0.418 \\
\hline Guinea - Conakry - imported - retail & 0 & 0 & 35 & 0.629 & 0.125 & 0 & 0 & 126 & 0.217 & 0.217 & 1 & 0 & 490 & 0.416 & 0.418 \\
\hline Guinea - Conakry - local - retail & 0 & 0 & 235 & 0.731 & 0.127 & 1 & 1 & 380 & 2.826 & 0.221 & 1 & 0 & 490 & 0.416 & 0.418 \\
\hline Lesotho - Mapoteng - retail & 0 & 0 & 1152 & 0.129 & 0.129 & . & 0 & 380 & 2.826 & 0.221 & 0 & 0 & 1152 & 0.129 & 0.129 \\
\hline Lesotho - Maputsoe - retail & 0 & 0 & 1279 & 0.078 & 0.038 & . & 0 & 380 & 2.826 & 0.221 & 0 & 0 & 1279 & 0.078 & 0.038 \\
\hline Lesotho - Maseru - retail & 0 & 0 & 1132 & 0.135 & 0.128 & 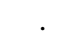 & 0 & 380 & 2.826 & 0.221 & 0 & 0 & 1132 & 0.135 & 0.128 \\
\hline Lesotho - Mokhotlong - retail & 0 & 0 & 1385 & 0.136 & 0.136 & . & 0 & 380 & 2.826 & 0.221 & 0 & 0 & 1385 & 0.136 & 0.136 \\
\hline Lesotho - Mount Moorosi - retail & 0 & 0 & 1294 & 0.290 & 0.290 & 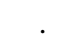 & 0 & 380 & 2.826 & 0.221 & 0 & 0 & 1294 & 0.290 & 0.290 \\
\hline Lesotho - Qacha's Nek - retail & 0 & 0 & 1272 & 0.111 & 0.099 & . & 0 & 380 & 2.826 & 0.221 & 0 & 0 & 1272 & 0.111 & 0.099 \\
\hline Madagascar - National Average - imported - retail & . & 1 & 95 & 0.380 & 0.153 & 0 & 0 & 180 & 0.038 & 0.038 & . & 1 & 172 & 0.317 & 0.328 \\
\hline Madagascar - National Average - local - retail & . & 1 & 35 & 0.440 & 0.070 & 0 & 1 & 113 & 0.060 & 0.035 & 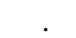 & 1 & 55 & 0.103 & 0.100 \\
\hline Malawi - Lilongwe - retail & . & 0 & 225 & 0.731 & 0.034 & 0 & 0 & . & $\cdot$ & . & ${ }^{\circ}$ & 0 & 1130 & 0.068 & 0.150 \\
\hline Malawi - Mzuzu - retail & & 1 & 7 & 0.072 & 0.039 & 0 & 1 & & & 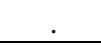 & & 1 & 350 & 0.027 & 0.029 \\
\hline
\end{tabular}


Annex 3 (continued). TVECM estimates, all markets

\begin{tabular}{|c|c|c|c|c|c|c|c|c|c|c|c|c|c|c|c|}
\hline Domestic price & & & ll sa & & & & & Pr & & & & & Po & & \\
\hline Country-market-quality-level & rank & seo & $\tau$ & R.1 & R.2 & rank & seo & $\tau$ & R.1 & R.2 & rank & seo & $\tau$ & R.1 & R.2 \\
\hline Mali - Bamako - imported - wholesale & . & 1 & 15 & 1.074 & 0.041 & 0 & 1 & 247 & 0.189 & 0.189 & $\cdot$ & 1 & 219 & 0.220 & 0.220 \\
\hline Mali - Bamako - local - wholesale & . & 1 & 3 & 0.817 & 0.034 & 0 & 0 & 228 & 0.104 & 0.104 & . & 1 & 419 & 0.261 & 0.405 \\
\hline Mali - Gao - imported - wholesale & . & 1 & 233 & 0.165 & 0.165 & . & 0 & 228 & 0.104 & 0.104 & . & 1 & 233 & 0.165 & 0.165 \\
\hline Mali - Gao - local - wholesale & . & 1 & 382 & 0.252 & 0.254 & ${ }^{\circ}$ & 0 & 228 & 0.104 & 0.104 & . & 1 & 382 & 0.252 & 0.254 \\
\hline Mali - Kayes - imported - wholesale & . & 1 & 61 & 0.588 & 0.107 & 0 & 0 & 261 & 0.663 & 0.663 & . & 1 & 122 & 0.134 & 0.177 \\
\hline Mali - Kayes - local - wholesale & . & 1 & 39 & 1.296 & 0.034 & 0 & 0 & 351 & 0.561 & 0.540 & . & 1 & 384 & 0.260 & 0.260 \\
\hline Mali - Mopti - imported - wholesale & . & 1 & 208 & 0.320 & 0.320 & . & 0 & 351 & 0.561 & 0.540 & . & 1 & 208 & 0.320 & 0.320 \\
\hline Mali - Mopti - local - wholesale & . & 1 & 262 & 0.181 & 0.181 & . & 0 & 351 & 0.561 & 0.540 & . & 1 & 262 & 0.181 & 0.181 \\
\hline Mali - Ségou - imported - wholesale & . & 1 & 231 & 0.273 & 0.258 & . & 0 & 351 & 0.561 & 0.540 & . & 1 & 231 & 0.273 & 0.258 \\
\hline Mali - Ségou - local - wholesale & . & 1 & 204 & 0.254 & 0.254 & . & 0 & 351 & 0.561 & 0.540 & . & 1 & 204 & 0.254 & 0.254 \\
\hline Mali - Sikasso - imported - wholesale & . & 1 & 240 & 0.207 & 0.207 & . & 0 & 351 & 0.561 & 0.540 & . & 1 & 240 & 0.207 & 0.207 \\
\hline Mali - Sikasso - local - wholesale & . & 1 & 289 & 0.241 & 0.241 & . & 0 & 351 & 0.561 & 0.540 & . & 1 & 289 & 0.241 & 0.241 \\
\hline Mali - Tombouctou - imported - wholesale & . & 1 & 215 & 0.178 & 0.175 & . & 0 & 351 & 0.561 & 0.540 & . & 1 & 215 & 0.178 & 0.175 \\
\hline Mali - Tombouctou - local - wholesale & . & 1 & 227 & 0.176 & 0.192 & . & 0 & 351 & 0.561 & 0.540 & . & 1 & 227 & 0.176 & 0.192 \\
\hline Mauritania - Nouakchott - imported - retail & 0 & 0 & 55 & 0.835 & 0.021 & 0 & 0 & 461 & 0.175 & 0.175 & 0 & 0 & 226 & 0.010 & 0.010 \\
\hline Mozambique - Angonia - retail & 1 & 1 & 39 & 1.816 & 0.021 & 0 & 0 & 347 & 0.139 & 0.139 & 1 & 1 & 500 & 0.047 & 0.047 \\
\hline Mozambique - Chokwe - retail & 1 & 0 & 32 & 0.276 & 0.024 & 0 & 0 & 114 & 0.281 & 0.281 & . & 1 & 81 & 0.015 & 0.015 \\
\hline Mozambique - Gorongosa - retail & 1 & 1 & 75 & 0.836 & 0.053 & 0 & 0 & 158 & 0.018 & 0.018 & . & 1 & 410 & 0.344 & 0.344 \\
\hline Mozambique - Manica - retail & 1 & 0 & 85 & 0.096 & 0.058 & 0 & 0 & 291 & 0.203 & 0.203 & . & 0 & 587 & 0.289 & 0.289 \\
\hline Mozambique - Maputo - retail & 1 & 1 & 31 & 4.444 & 0.023 & 0 & 0 & 104 & 0.025 & 0.025 & & 0 & 340 & 0.116 & 0.132 \\
\hline Mozambique - Maxixe - retail & 1 & 0 & 25 & 1.487 & 0.020 & 1 & 0 & 150 & 0.144 & 0.140 & 1 & 0 & 142 & 0.037 & 0.037 \\
\hline Mozambique - Milange - retail & . & 1 & 101 & 0.000 & 0.038 & 0 & 0 & 101 & 0.053 & 0.050 & . & 1 & 219 & 0.000 & 0.025 \\
\hline Mozambique - Montepuez - retail & 1 & 0 & 105 & 2.001 & 0.165 & 0 & 0 & 191 & 0.176 & 0.168 & . & 0 & 331 & 0.255 & 0.255 \\
\hline Mozambique - Nampula - retail & 1 & 1 & 45 & 2.420 & 0.058 & 1 & 1 & 179 & 0.200 & 0.191 & . & 0 & 579 & 0.111 & 0.216 \\
\hline Mozambique - Ribaue - retail & 1 & 0 & 12 & 5.452 & 0.016 & 0 & 0 & 12 & 3.532 & 0.013 & . & 0 & 530 & 0.083 & 0.083 \\
\hline Niger - Agadez - imported - retail & 1 & 1 & 209 & 0.129 & 0.056 & 0 & 1 & 444 & 0.025 & 0.127 & . & 1 & 537 & 0.215 & 0.215 \\
\hline Niger - Dosso - imported - retail & 1 & 1 & 139 & 1.390 & 0.057 & 1 & 1 & 442 & 0.033 & 0.277 & . & 1 & 438 & 0.222 & 0.206 \\
\hline Niger - Dosso - imported - wholesale & . & 1 & 37 & 1.504 & 0.032 & 0 & 0 & 340 & 0.514 & 0.359 & . & 1 & 426 & 0.220 & 0.220 \\
\hline Niger - Agadez - imported - wholesale & . & 1 & 157 & 0.375 & 0.061 & 0 & 0 & 416 & 0.000 & 0.789 & . & 1 & 581 & 0.205 & 0.205 \\
\hline Niger - Maradi - imported - retail & 1 & 1 & 129 & 0.152 & 0.042 & 0 & 0 & 423 & 0.024 & 1.539 & . & 0 & 570 & 0.173 & 0.173 \\
\hline Niger - Maradi - imported - wholesale & 1 & 1 & 49 & 0.147 & 0.041 & 1 & 0 & 351 & 0.163 & 0.803 & . & 1 & 495 & 0.241 & 0.242 \\
\hline Niger - Niamey - imported - retail & 1 & 1 & 75 & 0.914 & 0.038 & 1 & 1 & 410 & 0.057 & 0.522 & . & 1 & 438 & 0.189 & 0.187 \\
\hline Niger - Niamey - imported - wholesale & . & 1 & 15 & 1.577 & 0.024 & 0 & 1 & 340 & 0.162 & 0.198 & . & 1 & 403 & 0.196 & 0.192 \\
\hline Niger - Tillaberi - imported - retail & 1 & 1 & 95 & 1.257 & 0.064 & 0 & 0 & 420 & 0.010 & 0.047 & . & 1 & 354 & 0.204 & 0.204 \\
\hline Niger - Tillaberi - imported - wholesale & ${ }^{\circ}$ & 1 & 82 & 0.188 & 0.059 & 0 & 0 & 340 & 0.165 & 0.148 & . & 1 & 450 & 0.202 & 0.202 \\
\hline Niger - Zinder - imported - retail & 1 & 1 & 139 & 0.094 & 0.046 & 0 & 1 & 492 & 0.016 & 0.421 & . & 1 & 536 & 0.202 & 0.202 \\
\hline Niger - Zinder - imported - wholesale & & 1 & 98 & 0.182 & 0.066 & 0 & 0 & 382 & 0.154 & 0.396 & . & 1 & 495 & 0.260 & 0.238 \\
\hline Rwanda - Kigali - wholesale & & 0 & 244 & 0.000 & 0.012 & 0 & 0 & 477 & 0.020 & 0.020 & . & 0 & 357 & 0.017 & 0.000 \\
\hline
\end{tabular}

崩 
Annex 3 (continued). TVECM estimates, all markets

\begin{tabular}{|c|c|c|c|c|c|c|c|c|c|c|c|c|c|c|c|}
\hline \multirow{2}{*}{$\begin{array}{l}\text { Domestic price } \\
\text { Country-market-quality-level }\end{array}$} & \multicolumn{5}{|c|}{ All sample } & \multicolumn{5}{|c|}{ Pre } & \multicolumn{5}{|c|}{ Post } \\
\hline & rank & seo & $\tau$ & R.1 & R.2 & rank & seo & $\tau$ & R.1 & R.2 & rank & seo & $\tau$ & R.1 & R.2 \\
\hline Senegal - Dakar - imported - retail & . & 1 & 171 & 0.842 & 0.095 & & 0 & $\cdot$ & · & $\cdot$ & . & 1 & 400 & 0.117 & 0.218 \\
\hline Senegal - Diourbel - imported - retail & . & 0 & 51 & 0.165 & 0.061 & 0 & 0 & . & . & . & . & 0 & 307 & 0.181 & 0.181 \\
\hline Senegal - Fatick - imported - retail & . & 1 & 161 & 0.593 & 0.119 & . & 0 & . & . & . & . & 1 & 182 & 0.283 & 0.056 \\
\hline Senegal - Kaolack - imported - retail & . & 1 & 95 & 0.385 & 0.106 & . & 0 & . & . & . & . & 1 & 95 & 0.106 & 0.084 \\
\hline Senegal - Kolda - imported - retail & . & 1 & 79 & 1.448 & 0.075 & . & 0 & . & . & . & . & 0 & 261 & 0.119 & 0.119 \\
\hline Senegal - Louga - imported - retail & . & 1 & 11 & 0.486 & 0.016 & & 0 & . & . & . & . & 1 & 433 & 0.272 & 0.270 \\
\hline Senegal - Matam - imported - retail & . & 1 & 91 & 0.093 & 0.093 & 0 & 0 & . & . & . & . & 1 & 392 & 0.222 & 0.222 \\
\hline Senegal - SaintLouis - imported - retail & . & 1 & 115 & 0.200 & 0.057 & 0 & 0 & . & . & . & . & 1 & 457 & 0.259 & 0.259 \\
\hline Senegal - Tambacounda - imported - retail & . & 1 & 51 & 0.617 & 0.064 & . & 0 & 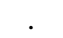 & . & . & . & 1 & 166 & 0.118 & 0.118 \\
\hline Senegal - Thies - imported - retail & . & 1 & 110 & 0.103 & 0.103 & . & 1 & . & . & . & . & 1 & 295 & 0.065 & 0.113 \\
\hline Senegal - Zguinchor - imported - retail & . & 1 & 190 & 0.170 & 0.170 & . & 1 & . & 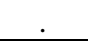 & 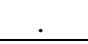 & . & 1 & 186 & 0.108 & 0.108 \\
\hline Somalia - Baidoa - imported - retail & & 0 & 125 & 0.835 & 0.033 & 1 & 0 & 231 & 0.205 & 0.205 & . & 1 & 297 & 0.018 & 0.116 \\
\hline Somalia - Belet Weyne - imported - retail & 1 & 0 & 85 & 0.624 & 0.038 & 1 & 1 & 122 & 0.037 & 0.037 & . & 1 & 479 & 0.025 & 0.287 \\
\hline Somalia - Borama - imported - retail & 0 & 1 & & & & 0 & 0 & & & & . & 0 & & & \\
\hline Somalia - Bossaso - imported - retail & 1 & 0 & 35 & 0.953 & 0.040 & 0 & 0 & 95 & 0.132 & 0.132 & . & 0 & 22 & 0.000 & 0.052 \\
\hline Somalia - Buale - imported - retail & & 0 & 157 & 0.560 & 0.044 & 1 & 0 & 547 & 0.043 & 0.878 & 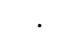 & 0 & 657 & 0.023 & 0.114 \\
\hline Somalia - Galkayo - imported - retail & 1 & 0 & 75 & 6.579 & 0.023 & 0 & 1 & 128 & 0.042 & 0.033 & . & 0 & 554 & 0.031 & 0.080 \\
\hline Somalia - Hargeisa - imported - retail & 0 & 1 & . & & & 0 & 0 & & & & 1 & 1 & . & & \\
\hline Somalia - Hudur - imported - retail & 1 & 0 & 15 & 0.010 & 0.024 & 1 & 1 & 374 & 0.069 & 0.189 & . & 1 & 435 & 0.062 & 0.062 \\
\hline Somalia - Kismayo - imported - retail & 1 & 1 & 15 & 0.162 & 0.052 & 1 & 1 & 60 & 0.024 & 0.059 & . & 1 & 628 & 0.070 & 0.138 \\
\hline Somalia - Lasanod - imported - retail & 1 & 0 & 77 & 0.014 & 0.022 & 0 & 0 & 371 & 0.032 & 5.523 & . & 1 & 119 & 0.000 & 0.039 \\
\hline Somalia - Marka - imported - retail & 1 & 0 & 15 & 0.027 & 0.027 & 1 & 0 & 119 & 0.112 & 0.112 & . & 1 & 106 & 0.000 & 0.089 \\
\hline Somalia - Mogadishu - imported - retail & & 1 & 283 & 0.039 & 0.039 & & 0 & 119 & 0.112 & 0.112 & . & 1 & 283 & 0.039 & 0.039 \\
\hline Tanzania - Dar es Salaam - wholesale & 1 & 1 & 153 & 0.039 & 0.039 & 0 & 0 & 169 & 0.056 & 0.056 & . & 0 & 153 & 0.014 & 0.014 \\
\hline Togo - Amegnran - imported - retail & 0 & 0 & 15 & 1.272 & 0.010 & 0 & 0 & 610 & 0.133 & 0.580 & 1 & 1 & 247 & 0.131 & 0.131 \\
\hline Togo - Anie - imported - retail & 1 & 1 & 125 & 1.507 & 0.071 & 0 & 0 & 244 & 0.064 & 0.064 & . & 1 & 479 & 0.237 & 0.237 \\
\hline Togo - Cinkassé - imported - retail & . & 1 & 81 & 0.523 & 0.048 & 1 & 1 & 306 & 0.160 & 0.160 & . & 1 & 459 & 0.350 & 0.274 \\
\hline Togo - Kara - imported - retail & & 1 & 45 & 0.838 & 0.026 & 0 & 0 & 246 & 0.107 & 0.135 & . & 1 & 597 & 0.240 & 0.295 \\
\hline Togo - Korbongou - imported - retail & 1 & 1 & 65 & 1.032 & 0.051 & 0 & 0 & 357 & 0.249 & 0.250 & . & 1 & 281 & 0.219 & 0.111 \\
\hline Togo - Lomé - imported - retail & 1 & 0 & 60 & 0.054 & 0.054 & 0 & 0 & 98 & 0.295 & 0.044 & . & 0 & 791 & 0.399 & 0.458 \\
\hline Tunisia - National Average - retail & 1 & 0 & 201 & 1.632 & 0.027 & 0 & 1 & 335 & 0.115 & 0.115 & 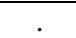 & 1 & 630 & 0.234 & 0.222 \\
\hline Uganda - Kampala - wholesale & . & 0 & 107 & 1.575 & 0.016 & 0 & 0 & 244 & 0.029 & 0.029 & . & 1 & 137 & 0.004 & 0.004 \\
\hline Zambia - National Average - local - retail & 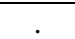 & 0 & 635 & 0.215 & 0.000 & 0 & 0 & . & . & 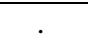 & . & 0 & 1240 & 0.000 & 0.021 \\
\hline
\end{tabular}


Annex 3 (continued). TVECM estimates, all markets

\begin{tabular}{|c|c|c|c|c|c|c|c|c|c|c|c|c|c|c|c|}
\hline \multirow{2}{*}{$\begin{array}{l}\text { Domestic price } \\
\text { Country-market-quality-level }\end{array}$} & \multicolumn{5}{|c|}{ All sample } & \multicolumn{5}{|c|}{ Pre } & \multicolumn{5}{|c|}{ Post } \\
\hline & rank & seo & $\tau$ & R.1 & R.2 & rank & seo & $\tau$ & R.1 & R.2 & rank & seo & $\tau$ & R.1 & R.2 \\
\hline Bolivia - Cochabamba - estaquilla - wholesale & 1 & 1 & 151 & 0.146 & 0.035 & 0 & 0 & 309 & 0.038 & 0.097 & & 0 & 202 & 0.006 & 0.006 \\
\hline Bolivia - Cochabamba - grano de oro - wholesale & 1 & 1 & 448 & 0.089 & 0.074 & 0 & 0 & 341 & 0.077 & 0.084 & 1 & 1 & 513 & 0.077 & 0.042 \\
\hline Bolivia - La Paz - estaquilla - wholesale & 1 & 1 & 134 & 0.486 & 0.077 & 0 & 0 & 214 & 0.101 & 0.074 & 1 & 1 & 158 & 0.885 & 0.101 \\
\hline Bolivia - La Paz - grano de oro - wholesale & 1 & 1 & 347 & 0.200 & 0.131 & 0 & 0 & 263 & 0.077 & 0.054 & 1 & 1 & 417 & 0.132 & 0.132 \\
\hline Bolivia - Santa Cruz - estaquilla - wholesale & 1 & 1 & 119 & 0.335 & 0.062 & 0 & 0 & 251 & 0.092 & 0.057 & 1 & 1 & 165 & 0.085 & 0.085 \\
\hline Bolivia - Santa Cruz - grano de oro - wholesale & 1 & 1 & 204 & 0.048 & 0.044 & 0 & 0 & 282 & 0.062 & 0.057 & . & 1 & 391 & 0.122 & 0.122 \\
\hline Colombia - Barranquilla - first quality - wholesale & 1 & 1 & 190 & 0.003 & 0.025 & 0 & 1 & 235 & 0.018 & 0.018 & . & 1 & 387 & 0.041 & 0.025 \\
\hline Colombia - Barranquilla - second quality - wholesale & 1 & 1 & 168 & 0.818 & 0.033 & 0 & 1 & 198 & 0.019 & 0.019 & . & 1 & 380 & 0.003 & 0.027 \\
\hline Colombia - Bogotá - first quality - wholesale & 1 & 1 & 215 & 0.549 & 0.013 & 0 & 1 & 268 & 0.025 & 0.025 & . & 0 & 540 & 0.046 & 0.038 \\
\hline Colombia - Bogotá - second quality - wholesale & 1 & 0 & 155 & 0.783 & 0.017 & 0 & 0 & 202 & 0.019 & 0.019 & . & 0 & 377 & 0.000 & 0.032 \\
\hline Colombia - Medellín - first quality - wholesale & 1 & 1 & 248 & 0.000 & 0.009 & 0 & 1 & 304 & 0.027 & 0.027 & . & 0 & 589 & 0.018 & 0.031 \\
\hline Colombia - National Average - first quality - retail & 1 & 0 & 279 & 0.776 & 0.011 & 0 & 1 & 332 & 0.021 & 0.021 & . & 0 & 796 & 0.014 & 0.027 \\
\hline Colombia - National Average - second quality - retail & 1 & 0 & 215 & 1.163 & 0.015 & 0 & 1 & 284 & 0.026 & 0.026 & & 0 & 636 & 0.000 & 0.031 \\
\hline Costa Rica - National Average - first quality - retail & 1 & 1 & 415 & 0.000 & 0.005 & 0 & 0 & 508 & 0.089 & 0.089 & 1 & 1 & 602 & 0.000 & 0.004 \\
\hline Costa Rica - National Average - second quality - retail & 1 & 1 & 51 & 0.000 & 0.013 & 0 & 0 & 436 & 0.146 & 0.146 & & 1 & 729 & 0.000 & 0.009 \\
\hline Dominican Republic - Santo Domingo - first quality - wholesale & 0 & 0 & 132 & 0.777 & 0.051 & 0 & 0 & 649 & 0.127 & 0.128 & 1 & 0 & 519 & 0.190 & 0.155 \\
\hline Dominican Republic - Santo Domingo - first quality - retail & 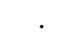 & 1 & 830 & 0.209 & 0.199 & 0 & 0 & 793 & 0.000 & 0.000 & - & 1 & 830 & 0.285 & 0.261 \\
\hline Dominican Republic - Santo Domingo - second quality - wholesale & 0 & 1 & 74 & 1.065 & 0.060 & 0 & 1 & 539 & 0.062 & 0.049 & 1 & 1 & 431 & 0.293 & 0.198 \\
\hline Dominican Republic - Santo Domingo - second quality - retail & . & 1 & 692 & 0.189 & 0.189 & 1 & 1 & 672 & 0.183 & 0.183 & . & 1 & 701 & 0.214 & 0.212 \\
\hline El Salvador - San Salvador - wholesale & 1 & 1 & 422 & 0.121 & 0.113 & 0 & 0 & 314 & 0.067 & 0.067 & 1 & 1 & 370 & 0.118 & 0.118 \\
\hline El Salvador - San Salvador - retail & 1 & 1 & 669 & 0.107 & 0.107 & 0 & 0 & 494 & 0.113 & 0.086 & 1 & 1 & 669 & 0.123 & 0.113 \\
\hline Guatemala - Guatemala City - first quality - wholesale & 1 & 0 & 252 & 0.716 & 0.083 & 0 & 0 & 318 & 0.118 & 0.113 & . & 0 & 481 & 0.247 & 0.247 \\
\hline Guatemala - Guatemala City - second quality - wholesale & . & 0 & 229 & 0.455 & 0.016 & & 0 & . & & & . & 0 & 366 & 0.234 & 0.234 \\
\hline Guatemala - National Average - second quality - retail & 1 & 1 & 370 & 0.000 & 0.009 & 0 & 0 & 415 & 0.062 & 0.062 & . & 1 & 759 & 0.000 & 0.018 \\
\hline Haiti - Hinche - imported - retail & . & 1 & 764 & 0.032 & 0.103 & 0 & 0 & 913 & 0.231 & 0.764 & . & 1 & 770 & 0.147 & 0.147 \\
\hline Haiti - Jacmel - imported - retail & . & 1 & 670 & 0.097 & 0.083 & 0 & 0 & 891 & 0.115 & 0.771 & . & 0 & 679 & 0.000 & 0.064 \\
\hline Haiti - Jeremie - imported - retail & . & 0 & 642 & 0.135 & 0.064 & 0 & 0 & 696 & 0.002 & 0.100 & . & 0 & 1056 & 0.051 & 0.122 \\
\hline Haiti - Ouanaminthe - imported - retail & . & 1 & 1334 & 0.028 & 0.106 & 0 & 0 & 756 & 0.088 & 0.088 & . & 0 & 1287 & 0.010 & 0.100 \\
\hline Haiti - Port-au-Prince - imported - retail & . & 1 & 548 & 0.000 & 0.075 & 0 & 0 & 780 & 0.064 & 0.064 & & 0 & 648 & 0.171 & 0.171 \\
\hline Honduras - San Pedro Sula - second quality - wholesale & . & 0 & 250 & 0.024 & 0.029 & . & 1 & . & . & . & . & 0 & 366 & 0.007 & 0.086 \\
\hline Honduras - Tegucigalpa - second quality - wholesale & 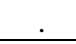 & 0 & 289 & 0.000 & 0.019 & & 1 & . & & $\dot{\square}$ & & 0 & 289 & 0.072 & 0.064 \\
\hline Mexico - Guadalajara - Sinaloa - wholesale & 1 & 0 & 105 & 0.172 & 0.022 & 0 & 1 & 167 & 0.031 & 0.031 & & 0 & 329 & 0.218 & 0.218 \\
\hline Mexico - Mexico City - Morelos - wholesale & 0 & 0 & 1392 & 0.000 & 0.088 & 0 & 0 & 744 & 0.017 & 0.017 & & 1 & 1392 & 0.026 & 0.081 \\
\hline Mexico - Mexico City - Sinaloa - wholesale & 1 & 0 & 236 & 0.362 & 0.036 & 0 & 1 & 187 & 0.028 & 0.028 & . & 0 & 509 & 0.060 & 0.140 \\
\hline Mexico - Puebla - Morelos - wholesale & 1 & 0 & 997 & 0.050 & 0.049 & 0 & 0 & 727 & 0.004 & 0.004 & & 1 & 620 & 0.011 & 0.036 \\
\hline
\end{tabular}


Annex 3 (continued). TVECM estimates, all markets

\begin{tabular}{|c|c|c|c|c|c|c|c|c|c|c|c|c|c|c|c|}
\hline Domestic price & & & ll sa & & & & & Pr & & & & & Po & & \\
\hline Country-market-quality-level & rank & seo & $\tau$ & R.1 & R.2 & rank & seo & $\tau$ & R.1 & R.2 & rank & seo & $\tau$ & R.1 & R.2 \\
\hline Nicaragua - Managua - first quality - wholesale & 1 & 1 & 253 & 0.167 & 0.053 & 0 & 0 & 443 & 0.019 & 0.372 & 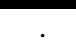 & 1 & 433 & 0.154 & 0.154 \\
\hline Nicaragua - Managua - first quality - retail & 1 & 1 & 318 & 0.122 & 0.059 & 0 & 0 & 537 & 0.007 & 0.370 & . & 1 & 621 & 0.233 & 0.233 \\
\hline Nicaragua - Managua - second quality - wholesale & 1 & 1 & 89 & 0.706 & 0.052 & 0 & 1 & 337 & 0.035 & 0.384 & . & 1 & 394 & 0.275 & 0.236 \\
\hline Nicaragua - Managua - second quality - retail & 1 & 1 & 294 & 0.719 & 0.070 & 0 & 0 & 439 & 0.048 & 0.408 & 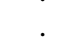 & 1 & 486 & 0.195 & 0.195 \\
\hline Nicaragua - Managua - third quality - wholesale & 1 & 1 & 42 & 0.851 & 0.039 & 1 & 1 & 302 & 0.056 & 0.201 & . & 1 & 288 & 0.186 & 0.167 \\
\hline Nicaragua - Managua - third quality - retail & 1 & 1 & 212 & 0.788 & 0.078 & 0 & 1 & 352 & 0.030 & 0.422 & . & 1 & 297 & 0.176 & 0.148 \\
\hline Nicaragua - National Average - first quality - wholesale & . & 1 & 463 & 0.178 & 0.171 & . & 0 & 352 & 0.030 & 0.422 & . & 1 & 463 & 0.178 & 0.171 \\
\hline Nicaragua - National Average - second quality - wholesale & . & 1 & 407 & 0.241 & 0.207 & . & 0 & 352 & 0.030 & 0.422 & . & 1 & 407 & 0.241 & 0.207 \\
\hline Nicaragua - National Average - second quality - retail & 1 & 1 & 315 & 0.778 & 0.100 & 0 & 0 & 421 & 0.025 & 0.400 & . & 1 & 432 & 0.154 & 0.154 \\
\hline Nicaragua - National Average - first quality - retail & 1 & 1 & 573 & 0.160 & 0.161 & 0 & 0 & 526 & 0.037 & 0.768 & 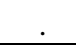 & 1 & 604 & 0.206 & 0.206 \\
\hline Panama - Panama City - first quality - wholesale & 1 & 1 & 119 & 0.055 & 0.055 & 1 & 1 & 337 & 0.050 & 0.050 & 1 & 1 & 495 & 0.157 & 0.157 \\
\hline Panama - Panama City - first quality - retail & . & 1 & 348 & 0.760 & 0.071 & 0 & 0 & 541 & 0.057 & 0.057 & . & 1 & 687 & 0.251 & 0.251 \\
\hline Peru - Lima - milled corriente - retail & 0 & 1 & 452 & 0.275 & 0.234 & 0 & 0 & 417 & 0.030 & 0.030 & 1 & 1 & 404 & 0.131 & 0.131 \\
\hline Peru - Lima - milled superior - retail & 0 & 0 & 605 & 0.730 & 0.035 & 0 & 0 & 716 & 0.009 & 0.010 & 1 & 1 & 856 & 0.164 & 0.160 \\
\hline Peru - National Average - milled corriente - wholesale & 1 & 1 & 55 & 0.412 & 0.071 & 0 & 0 & 181 & 0.047 & 0.032 & 1 & 1 & 99 & 0.065 & 0.065 \\
\hline Peru - National Average - paddy - wholesale & 1 & 1 & 4 & 0.113 & 0.113 & 0 & 0 & 2 & 0.046 & 0.043 & 1 & 1 & & & . \\
\hline
\end{tabular}

Notes: Using Vietnam 25\% brokens as the international reference price. Pre=sample period from Jan 2000 to Dec 2007 . Post=sample period from Jan 2008 to Dec 2012 . rank=1 if linearly

cointegrated. seo=1 if threshold cointegrated. $\boldsymbol{\tau}=$ threshold. R.1=Regime 1 adjustment parameters from the sum of the elements in $\boldsymbol{\alpha}_{\mathbf{1}}$. R.2=Regime 2 adjustment parameters from the sum of the elements in $\boldsymbol{\alpha}_{2}$. "."=not calculated. Source of raw data: FAO-GIEWS. 
Annex 4. TVECM estimates using Vietnam 5\% as IRP, by country

\begin{tabular}{|c|c|c|c|c|c|c|c|c|c|}
\hline \multirow[b]{2}{*}{ Region/Country } & \multicolumn{3}{|c|}{ All sample } & \multicolumn{3}{|c|}{ Pre } & \multicolumn{3}{|c|}{ Post } \\
\hline & & R.1 & R.2 & & R.1 & R.2 & & R.1 & R.2 \\
\hline All markets & 175 & 0.943 & 0.075 & 264 & 0.235 & 0.130 & 371 & 0.146 & 0.148 \\
\hline Asia & 55 & 0.847 & 0.075 & 98 & 0.109 & 0.099 & 161 & 0.111 & 0.121 \\
\hline South/Central Asia & 22 & 0.441 & 0.174 & 5 & 0.122 & 0.134 & 60 & 0.083 & 0.146 \\
\hline Bangladesh & 5 & 0.104 & 0.104 & 3 & 0.106 & 0.087 & 6 & 0.056 & 0.056 \\
\hline Bhutan* & 7 & 0.024 & 0.291 & 4 & 0.102 & 0.084 & 7 & 0.024 & 0.291 \\
\hline Mongolia* & 124 & 2.596 & 0.021 & . & . & & 425 & 0.056 & 0.027 \\
\hline Nepal & 19 & 0.265 & 0.265 & 9 & 0.234 & 0.148 & 9 & 0.228 & 0.228 \\
\hline Sri Lanka & 5 & 0.306 & 0.216 & 5 & 0.100 & 0.358 & 19 & 0.161 & 0.161 \\
\hline Southeast Asia & 61 & 0.923 & 0.057 & 113 & 0.106 & 0.093 & 180 & 0.116 & 0.116 \\
\hline Indonesia* & 239 & 0.375 & 0.157 & 1 & 0.493 & 0.219 & 239 & 0.375 & 0.157 \\
\hline Lao & 53 & 0.448 & 0.035 & 85 & 0.151 & 0.101 & 164 & 0.044 & 0.060 \\
\hline Philippines & 44 & 1.187 & 0.049 & 137 & 0.055 & 0.079 & 178 & 0.121 & 0.128 \\
\hline Timor Leste* & 290 & 0.316 & 0.356 & 2 & 0.248 & 0.139 & 290 & 0.316 & 0.356 \\
\hline Africa & 186 & 1.063 & 0.082 & 283 & 0.383 & 0.177 & 409 & 0.163 & 0.172 \\
\hline East/South Africa & 272 & 1.374 & 0.062 & 218 & 0.666 & 0.123 & 502 & 0.106 & 0.129 \\
\hline Burundi & 7 & 1.419 & 0.012 & 469 & 0.267 & 0.267 & 556 & 0.004 & 0.004 \\
\hline Djibouti & 185 & 0.868 & 0.071 & 303 & 0.091 & 0.082 & 525 & 0.231 & 0.220 \\
\hline Lesotho* & 1233 & 0.151 & 0.140 & 365 & 2.996 & 0.235 & 1233 & 0.151 & 0.140 \\
\hline Madagascar & 18 & 0.440 & 0.081 & 121 & 0.037 & 0.032 & 70 & 0.260 & 0.207 \\
\hline Malawi & 106 & 0.992 & 0.044 & . & . & & 700 & 0.054 & 0.105 \\
\hline Mozambique & 60 & 1.461 & 0.047 & 157 & 0.426 & 0.127 & 305 & 0.138 & 0.139 \\
\hline Rwanda* & 211 & 0.000 & 0.014 & 415 & 0.064 & 0.012 & 321 & 0.016 & 0.000 \\
\hline Somalia & 64 & 2.694 & 0.051 & 141 & 0.097 & 0.103 & 318 & 0.030 & 0.128 \\
\hline Tanzania & 101 & 0.257 & 0.042 & 151 & 0.046 & 0.046 & 101 & 0.000 & 0.017 \\
\hline Tunisia* & 170 & 1.838 & 0.025 & 279 & 0.032 & 0.049 & 578 & 0.217 & 0.203 \\
\hline Uganda & 74 & 1.813 & 0.020 & 226 & 0.024 & 0.024 & 107 & 0.007 & 0.007 \\
\hline Zambia* & 602 & 0.317 & 0.000 & & & & 1170 & 0.001 & 0.013 \\
\hline
\end{tabular}

Notes: Regional averages are weighted based on number of markets in each country. R.1=Regime 1 adjustment parameters from the sum of the elements in $\alpha_{1}$. R.2=Regime 2 adjustment parameters from the sum of the elements in $\alpha_{2} . \tau=$ threshold. "." =not calculated. Pre=sample period from Jan 2000 to Dec 2007. Post=sample period from Jan 2008 to Dec 2012. IRP=international reference price. *not cointegrated with V5. + excluding markets marked with *. 
Annex 4 (continued). TVECM estimates using Vietnam 5\% as IRP, by country

\begin{tabular}{|c|c|c|c|c|c|c|c|c|c|}
\hline \multirow{2}{*}{ Region/Country } & \multicolumn{3}{|c|}{ All sample } & \multicolumn{3}{|c|}{ Pre } & \multicolumn{3}{|c|}{ Post } \\
\hline & & R.1 & R.2 & & R.1 & R.2 & & R.1 & $\mathbf{R . 2}$ \\
\hline West/Central Africa & 145 & 0.911 & 0.091 & 319 & 0.226 & 0.208 & 364 & 0.191 & 0.193 \\
\hline Benin & 115 & 0.792 & 0.042 & 335 & 0.034 & 0.095 & 486 & 0.114 & 0.123 \\
\hline Burkina Faso & 231 & 0.672 & 0.150 & 285 & 0.123 & 0.169 & 323 & 0.197 & 0.187 \\
\hline Cameroon & 85 & 1.029 & 0.057 & 331 & 0.103 & 0.138 & 364 & 0.213 & 0.204 \\
\hline Cape Verde & 113 & 0.781 & 0.033 & 331 & 0.185 & 0.167 & 576 & 0.104 & 0.157 \\
\hline Chad & 261 & 0.513 & 0.096 & 545 & 0.229 & 0.426 & 517 & 0.233 & 0.230 \\
\hline Congo & 318 & 0.662 & 0.087 & 465 & 0.191 & 0.555 & 451 & 0.128 & 0.132 \\
\hline Gabon & 476 & 0.679 & 0.176 & . & . & . & 635 & 0.286 & 0.286 \\
\hline Ghana & 358 & 0.183 & 0.033 & 475 & 0.051 & 0.074 & 500 & 0.400 & 0.400 \\
\hline Guinea & 102 & 4.965 & 0.066 & 228 & 1.603 & 0.223 & 430 & 0.421 & 0.422 \\
\hline Mali & 154 & 0.384 & 0.174 & 287 & 0.388 & 0.389 & 190 & 0.194 & 0.202 \\
\hline Mauritania & 27 & 1.510 & 0.020 & 449 & 0.163 & 0.163 & 140 & 0.006 & 0.006 \\
\hline Niger & 89 & 1.398 & 0.059 & 317 & 0.086 & 0.089 & 429 & 0.176 & 0.182 \\
\hline Senegal & 71 & 0.675 & 0.073 & . & . & . & 231 & 0.166 & 0.142 \\
\hline Togo & 76 & 1.270 & 0.053 & 240 & 0.164 & 0.133 & 440 & 0.265 & 0.255 \\
\hline Latin America & 267 & $\mathbf{0 . 7 5 8}$ & 0.061 & 397 & 0.056 & 0.064 & 494 & 0.138 & 0.120 \\
\hline Central America & 329 & 0.628 & 0.069 & 463 & 0.063 & 0.078 & 546 & 0.145 & 0.148 \\
\hline Costa Rica & 201 & 0.553 & 0.008 & 468 & 0.130 & 0.130 & 613 & 0.000 & 0.005 \\
\hline Dominican Rep & 170 & 1.312 & 0.057 & 639 & 0.077 & 0.079 & 581 & 0.250 & 0.209 \\
\hline El Salvador & 298 & 0.511 & 0.074 & 370 & 0.041 & 0.049 & 479 & 0.119 & 0.115 \\
\hline Guatemala & 251 & 0.401 & 0.040 & 372 & 0.088 & 0.088 & 455 & 0.168 & 0.171 \\
\hline Haiti & 741 & 0.080 & 0.106 & 706 & 0.075 & 0.093 & 841 & 0.062 & 0.114 \\
\hline Honduras & 135 & 0.005 & 0.028 & . & . & . & 307 & 0.043 & 0.085 \\
\hline Mexico* & 510 & 0.047 & 0.034 & 446 & 0.019 & 0.019 & 678 & 0.039 & 0.090 \\
\hline Nicaragua & 249 & 0.987 & 0.103 & 326 & 0.056 & 0.092 & 404 & 0.227 & 0.197 \\
\hline Panama & 135 & 1.146 & 0.046 & 405 & 0.053 & 0.053 & 558 & 0.190 & 0.190 \\
\hline South America & 141 & 1.020 & 0.045 & 276 & 0.043 & 0.039 & 385 & 0.124 & 0.060 \\
\hline Bolivia & 118 & 0.504 & 0.065 & 259 & 0.065 & 0.054 & 265 & 0.279 & 0.089 \\
\hline Colombia & 129 & 1.577 & 0.022 & 265 & 0.029 & 0.031 & 483 & 0.010 & 0.020 \\
\hline Peru & 196 & 0.817 & 0.054 & 322 & 0.035 & 0.032 & 398 & 0.078 & 0.092 \\
\hline All $\mathrm{m}$ & 175 & 0.943 & 0.075 & 264 & 0.235 & 0.130 & 371 & 0.146 & 0.148 \\
\hline All cointegrated+ & 136 & 0.947 & 0.076 & 258 & 0.134 & 0.129 & 337 & 0.146 & 0.151 \\
\hline
\end{tabular}

Notes: Regional averages are weighted based on number of markets in each country. R.1=Regime 1 adjustment parameters from the sum of the elements in $\alpha_{1}$. R.2=Regime 2 adjustment parameters from the sum of the elements in $\alpha_{2} . \tau$ = threshold. "." =not calculated. Pre=sample period from Jan 2000 to Dec 2007. Post=sample period from Jan 2008 to Dec 2012. IRP=international reference price *not cointegrated with V5. + excluding markets marked with *. 


\section{References}

Abbott, P., \& Borot de Battisti, A. (2011). Recent Global Food Price Shocks: Causes, Consequences and Lessons for African Governments and Donors. Journal of African Economies, 20(suppl 1), i12-i62.

Acharya, S. S., Chand, R., Birthal, P. S., Kumar, S., \& Negi, D. S. (2012). Market integration and price transmission in India: A case of rice and wheat with special reference to the world food crisis of 2007/08. Food and Agriculture Organization of the United Nations. Retrieved from http://www.fao.org/docrep/016/an034e/an034e00.pdf

ADB. (2008). Soaring Food Prices: Response to the Crisis. Manila, Philippines: Asian Development Bank. Retrieved from http://www.adb.org/Documents/Papers/soaring-food-prices/soaringfood-prices.pdf

Alam, M. J., Begum, I. A., Buysse, J., McKenzie, A. M., Wailes, E. J., \& Van Huylenbroeck, G. (2010). Testing asymmetric price transmission in the vertical supply chain in de-regulated rice markets in Bangladesh. Presented at the Agricultural and Applied Economics Association 2010 Annual Meeting, Denver, Colorado. Retrieved from http://ageconsearch.umn.edu/bitstream/61374/2/AAEA\%2c\%20Denver\%2c\%20Colrado\%2c \%202010.pdf

Alam, M. J., McKenzie, A., Buysse, J., Begum, I. A., Wailes, E., \& Van Huylenbroeck, G. (2012). Measuring Market Integration in the Presence of Threshold Effect: The Case of Bangladesh Rice Markets. Presented at the 2012 Annual Meeting, Seattle, Washington: Agricultural and Applied Economics Association. Retrieved from http://purl.umn.edu/124435

Ashraf, M. (2008). Econometric analysis of the impact of domestic rice procurement policy on producer price: the case of rice in Bangladesh. Jurnal Agro Ekonomi, 26(1), 80-89.

Asia Society, \& IRRI. (2010). Never an Empty Bowl: Sustaining Food Security in Asia. Retrieved from http://asiasociety.org/files/pdf/FoodSecurityTF_online.pdf

Australian Broadcasting Corporation. (2008, April 14). Asian giants vulnerable to rising food prices: World Bank. ABC News. Retrieved from http://www.abc.net.au/news/2008-04-14/asiangiants-vulnerable-to-rising-food-prices/2403166

Bakhshoodeh, M. (2010). Impacts of world prices transmission to domestic rice markets in rural Iran. Food Policy, 35(1), 12-19. doi:doi: 10.1016/j.foodpol.2009.06.006

Baltzer, K. (2013). International to domestic price transmission in fourteen developing countries during the 2007-08 food crisis (No. 2013/031). UNU-WIDER. Retrieved from http://www.wider.unu.edu/publications/working-papers/2013/en_GB/wp2013-031/

Baquedano, F. G., Liefert, W., \& Shapouri, S. (2011). World market integration for export and food crops in developing countries: a case study for Mali and Nicaragua. Agricultural Economics. doi:10.1111/j.1574-0862.2011.00540.x

Baulch, B., Hansen, H., Trung, L. D., \& Tam, T. N. M. (2008). The spatial integration of paddy markets in Vietnam. Journal of Agricultural Economics, 59(2), 271-295. doi:10.1111/j.14779552.2007.00148.x

Benson, T., Minot, N., Pender, J., Robles, M., \& von Braun, J. (2008). Global Food Crises: Monitoring and Assessing Impact to Inform Policy Responses (Food Policy Report No. 19). Washington, DC: International Food Policy Research Institute. Retrieved from http://www.ifpri.org/sites/default/files/publications/pr19.pdf 
Benson, T., Minot, N., Pender, J., Robles, M., \& von Braun, J. (2013). Information to guide policy responses to higher global food prices: The data and analyses required. Food Policy, 38, 4758. doi:10.1016/j.foodpol.2012.10.001

Briones, R. (2012). Should the Philippines tariffy its quantitative restriction on rice? (No. 2012-16). Philippine Institute for Development Studies. Retrieved from http://dirp3.pids.gov.ph/ris/pn/pidspn1216.pdf

Butler, J. S., \& Moser, C. (2010). Structural model of agricultural markets in developing countries. American Journal of Agricultural Economics, 92(5), 1364 -1378.

Chen, Q., Goh, C.-C., Sun, B., \& Xu, L. C. (2011). Market integration in the People's Republic of China. Asian Development Review, 28(1), 72-93.

Chulaphan, W., Jatuporn, C., Chen, S.-E., \& Jierwiriyapant, P. (2012). Causal impact price transmission of the rice markets in Thailand. Presented at the Modelling, Identification and Control / 770: Advances in Computer Science and Engineering, Phuket, Thailand. Retrieved from http://aa.npust.edu.tw/doc/6/101\%E8\%A3\%9C\%E5\%8A\%A9/1/Causal\%20price\%20impact $\% 20$ transmission\%20of\%20rice\%20markets\%20in\%20Thailand_769_051_.pdf

Clarete, R., Adriano, L., \& Esteban, A. (2013). Rice trade and price volatility: Implications on ASEAN and global food security (No. 368). Asian Development Bank (ADB). Retrieved from http://www.adb.org/sites/default/files/pub/2013/ewp-368.pdf

Cororaton, C. (2006). Philippine rice and rural poverty: an impact analysis of market reform using CGE (No. 96). International Food Policy Research Institute. Retrieved from http://ageconsearch.umn.edu/bitstream/58578/2/mtidp96.pdf

Coxhead, I., Linh, V. H., \& Tam, L. D. (2012). Global market shocks and poverty in Vietnam: the case of rice. Agricultural Economics, 43(5), 575-592. doi:10.1111/j.1574-0862.2012.00604.x

Cudjoe, G., Breisinger, C., \& Diao, X. (2008). Local impacts of a global crisis: food price transmission and poverty impacts in Ghana (No. 00842). International Food Policy Research Institute. Retrieved from http://www.ifpri.org/sites/default/files/publications/ifpridp00842.pdf

Dawe, D. (2008a). Can Indonesia trust the world rice market? Bulletin of Indonesian Economic Studies, 44(1), 115-132. doi:Article

Dawe, D. (2008b). Have recent increases in international cereal prices been transmitted to domestic economies? The experience in seven large Asian countries (No. 08-03). FAO.

Dawe, D. (2009). The Unimportance of "Low" World Grain Stocks for Recent World Price Increases (ESA Working Paper No. 09-01). Rome, Italy: Food and Agriculture Organization of the United Nations (FAO). Retrieved from ftp://ftp.fao.org/docrep/fao/011/aj989e/aj989e.pdf

Dawe, D. (Ed.). (2010). The Rice Crisis: Markets, Policies and Food Security. Earthscan and FAO.

Dawe, D., \& Maltsoglou, I. (2009). Analyzing the impact of food price increases: assumptions about marketing margins can be crucial (ESA Working Paper No. 09-02) (p. 12). FAO. Retrieved from ftp://ftp.fao.org/docrep/fao/011/aj990e/aj990e.pdf

Demeke, M., Pangrazio, G., \& Maetz, M. (2008). Country responses to the food security crisis: Nature and preliminary implications of the policies pursued. Rome, Italy: Food and Agriculture Organization of the United Nations. Retrieved from http://www.fao.org/fileadmin/user_upload/ISFP/pdf_for_site_Country_Response_to_the_Foo d_Security.pdf 
Dewbre, J., Giner, C., Thompson, W., \& Von Lampe, M. (2008). High food commodity prices: will they stay? who will pay? Agricultural Economics, 39, 393-403. doi:10.1111/j.15740862.2008.00346.x

Durand-Morat, A., \& Wailes, E. (2011). Rice Trade Policies and Their Implications for Food Security. Presented at the 2011 Annual Meeting of the Agricultural and Applied Economics Association, Pittsburgh, Pennsylvania. Retrieved from http://ageconsearch.umn.edu/bitstream/103818/2/Selected\%20paper\%20\%2313420\%20Dura nd\%20Morat\%20and\%20Wailes.pdf

Edward Yu, T.-H., Tokgoz, S., Wailes, E., \& Chavez, E. (2011). A quantitative analysis of trade policy responses to higher world agricultural commodity prices. Food Policy, In Press, Corrected Proof. doi:doi: 10.1016/j.foodpol.2011.07.001

FAO. (2008). High food prices and food security - threats and opportunities. Rome, Italy: Food and Agriculture Organization of the United Nations (FAO). Retrieved from http://www.fao.org/docrep/011/i0291e/i0291e00.htm

FAO. (2010). Addressing Food Insecurity in Protracted Crises. Rome, Italy: Food and Agriculture Organization of the United Nations (FAO). Retrieved from http://www.fao.org/publications/sofi/en/

FAO. (2011). How does international price volatility affect domestic economies and food security? Rome, Italy: Food and Agriculture Organization of the United Nations. Retrieved from http://www.fao.org/docrep/014/i2330e/i2330e00.htm

FAO \& OECD. (2011). Price Volatility in Food and Agricultural Markets: Policy Responses. Retrieved from http://www.ifad.org/operations/food/documents/g20.pdf

Fiamohe, R., Seck, P., Alia, D., \& Diagne, A. (2013). Price transmission analysis using threshold models: an application to local rice markets in Benin and Mali. Food Security, 5(3), 427-438. doi:10.1007/s12571-013-0254-Z

G20 Agriculture Ministers. (2011). Action plan on food price volatility and agriculture. In Ministerial Declaration. Paris, France. Retrieved from http://agriculture.gouv.fr/IMG/pdf/2011-06-23__Action_Plan_-_VFinale.pdf

Ghafoor, A., \& Islam, M. (2012). Market integration and price transmission in rice markets of Pakistan (No. 12-08). South Asia Network of Economic Research Institutes. Retrieved from http://www.saneinetwork.net/Files/3008201204262612.08.AGhafoor.pdf

Ghosh, M. (2010). Spatial price linkages in regional food grain markets in India. Margin: The Journal of Applied Economic Research, 4(4), 495-516. doi:10.1177/097380101000400405

Ghosh, M. (2011). Agricultural policy reforms and spatial integration of food grain markets in India. Journal of Economic Development, 36(2), 15-37.

Ghoshray, A. (2008). Asymmetric Adjustment of Rice Export Prices: The Case of Thailand and Vietnam. International Journal of Applied Economics, 5(2), 80-91.

Gilbert, C. L. (2010). How to understand high food prices. Journal of Agricultural Economics, 61(2), 398-425. doi:10.1111/j.1477-9552.2010.00248.x

Greb, F., Jamora, N., Mengel, C., von Cramon-Taubadel, S., \& Würriehausen, N. (2012). Cereal price transmission from international to domestic markets in Africa. Presented at the African Economic Conference, Kigali, Rwanda. Retrieved from http://www.uneca.org/sites/default/files/page_attachments/aec2012-336.pdf 
Greb, F., Krivobokova, T., Munk, A., \& von Cramon-Taubadel, S. (2014). Regularized Bayesian estimation in generalized threshold regression models. Bayesian Analysis, 9(1), 171-196. doi:10.1214/13-BA850

Greb, F., von Cramon-Taubadel, S., Krivobokova, T., \& Munk, A. (2013). The Estimation of Threshold Models in Price Transmission Analysis. American Journal of Agricultural Economics, 900-916. doi:10.1093/ajae/aat006

Headey, D. (2011). Rethinking the global food crisis: The role of trade shocks. Food Policy, 36(2), 136-146. doi:doi: 10.1016/j.foodpol.2010.10.003

Headey, D., \& Fan, S. (2008). Anatomy of a crisis: the causes and consequences of surging food prices. Agricultural Economics, 39, 375-391. doi:10.1111/j.1574-0862.2008.00345.x

Headey, D., \& Fan, S. (2010). Reflections on the Global Food Crisis How Did It Happen? How Has It Hurt? And How Can We Prevent the Next One? (Research Monograph No. 165). Washington, DC: International Food Policy Research Institute. Retrieved from http://www.ifpri.org/sites/default/files/publications/rr165.pdf

Headey, D., Malaiyandi, S., \& Fan, S. (2010). Navigating the perfect storm: reflections on the food, energy, and financial crises. Agricultural Economics, 41, 217-228. doi:10.1111/j.15740862.2010.00502.x

Hernandez-Villafuerte, K. (2011, July 24). Relationship between spatial price transmission and geographical distance in Brazil. Selected Poster presented at the Agricultural \& Applied EconomicsAssociation's 2011 AAEA \& NAREA Joint Annual Meeting, Pittsburgh, Pennsylvania. Retrieved from http://ageconsearch.umn.edu/bitstream/103677/2/RELATIONSHIP\%20BETWEEN\%20SPA TIAL\%20PRICE\%20TRANSMISSION\%20AND\%20GEOGRAPHICAL\%20DISTANCE\% 20IN\%20BRAZIL.pdf

Hossain, M. I., \& Verbeke, W. (2010). Evaluation of rice markets integration in Bangladesh. The Lahore Journal of Economics, 15(2), 77-96.

Ianchovichina, E., Loening, J., \& Wood, C. (2012). How vulnerable are Arab countries to global food price shocks? (Policy Research Working Paper No. 6018). World Bank.

Imai, K., Gaiha, R., \& Thapa, G. (2008). Transmission of world commodity prices to domestic commodity prices in India and China (Working Paper No. 45). Brooks World Poverty Institute. Retrieved from http://www.bwpi.manchester.ac.uk/resources/Working-Papers/bwpiwp-4508.pdf

IRRI. (2008). Responding to the rice crisis: how IRRI can work with its partners. International Rice Research Institute. Retrieved from http://beta.irri.org/solutions/images/Responding_to_the_Rice_Crisis.pdf

Ivanic, M., \& Martin, W. (2008). Implications of higher global food prices for poverty in low-income countries. Agricultural Economics, 39, 405-416. doi:10.1111/j.1574-0862.2008.00347.x

Jayasuriya, S., Kim, J. H., \& Kumar, P. (2007). International and internal market integration in Indian agriculture: a study of the Indian rice market. In Pro-poor development in low income countries: Food, agriculture, trade, and environment. Montpellier, France. Retrieved from http://ageconsearch.umn.edu/bitstream/7935/1/sp07ja05.pdf

Jolejole, M. C., \& Mallory, M. (2011). Analyzing Market Price Transmission, Government Intervention and Weather Shocks for Rice Market in the Philippines. Presented at the 2011 AAEA and NAREA Joint Annual Meeting, Pittsburgh, Pennsylvania. Retrieved from http://ageconsearch.umn.edu/bitstream/103163/2/JolejoleMallory_AAEA2011.pdf 
Keats, S., Wiggins, S., Compton, J., \& Vigneri, M. (2010). Food price transmission: rising international cereals prices and domestic markets (Project Briefings No. 48). Overseas Development Institute. Retrieved from http://www.odi.org.uk/resources/download/5079.pdf

Knowledge Bank, IRRI. (2006). Breeding for grain quality. International Rice Research Institute. Retrieved from http://www.knowledgebank.irri.org/ricebreedingcourse/bodydefault.htm\#Grain_quality.htm

Love, B. (2008, May 30). Food prices to stay high. Reuters. Paris. Retrieved from http://uk.reuters.com/article/2008/05/29/uk-food-outlook-report-idUKL2977793320080529

Lustig, N. (2009). Coping with Rising Food Prices: Policy Dilemmas in the Developing World (No. 0907). New Orleans, LA: Tulane University. Retrieved from http://econ.tulane.edu/RePEc/pdf/tul0907.pdf

Marcelo, E. (2014, March 28). High-ranking officials involved in P56-B rice smuggling - Customs report. GMA Network News. Manila, Philippines. Retrieved from http://www.gmanetwork.com/news/story/354604/news/nation/high-ranking-officialsinvolved-in-p56-b-rice-smuggling-customs-report

Marks, D. (2008). Unity or diversity? Market integration and long-run economic growth in Indonesia. In "Economic Change Around the Indian Ocean in the Very Long Run." The University of Warwick in Venice, Palazzo Pesaro Papafava.

Martin, W., \& Anderson, K. (2012). Export Restrictions and Price Insulation During Commodity Price Booms. American Journal of Agricultural Economics, 94(2), 422 -427.

Matriz, M. J. (2008). Price transmission mechanism in the Philippine rice industry (M.S.). University of Delaware, Department of Food and Resource Economics.

McCalla, A. F. (2009). World Food Prices: Causes and Consequences. Canadian Journal of Agricultural Economics/Revue Canadienne D'agroeconomie, 57(1), 23-34. doi:10.1111/j.1744-7976.2008.01136.x

Minot, N. (2010). Transmission of world food price changes to African markets and its effect on household welfare. Maputo, Mozambique: Comesa-MSU-IFPRI African Agricultural Markets Project (AAMP). Retrieved from http://programmes.comesa.int/attachments/186_AAMP\%20Food\%20price\%20transmission\% 20in\%20Africa\%20\%285\%20Jan\%29.pdf

Mondi, A., Koo, C. M., \& Kim, W. J. (2010). Oil shocks and the world rice market puzzle: a structural VAR analysis. Presented at the APEA 2010, Hong Kong: Asia-Pacific Economic Association. Retrieved from http://www.apeaweb.org/confer/hk10/papers/mondi_alberto.pdf

Moser, C., Barrett, C., \& Minten, B. (2009). Spatial integration at multiple scales: rice markets in Madagascar. Agricultural Economics, 40(3), 281-294. doi:10.1111/j.15740862.2009.00380.x

Myint, T. (2007, January). Myanmar rice market: market integration and price causality (Ph.D.). Yezin Agricultural University.

Nielsen, C. P., \& Yu, W. (2002). Integration of the international rice market: implications for trade liberalization. Danish Research Institute of Food Economics.

Ohen, S. B., \& Abang, S. O. (2011). Evaluation of price linkages within the supply chain of rice markets in Cross River State, Nigeria. Journal of Stored Products and Postharvest Research, 2(8), 151-155. 
Piesse, J., \& Thirtle, C. (2009). Three bubbles and a panic: an explanatory review of recent food commodity price events. Food Policy, 34(2), 119-129. doi:doi:

10.1016/j.foodpol.2009.01.001

Press Trust Of India, N. D. (2008, April 10). Food prices to remain high, more riots feared: FAO. New Delhi. Retrieved from http://www.business-standard.com/india/news/food-prices-toremain-high-more-riots-feared-fao/319632/

Rapsomanikis, G. (2011). Price transmission and volatility spillovers in food markets. In A. Prakash (Ed.), Safeguarding food security in volatile global markets (pp. 144-163). FAO.

Reyes, C., Sobrevinas, A., Bancolita, J., \& de Jesus, J. (2009). Analysis of the impact of changes in the prices of rice and fuel on poverty in the Philippines (PIDS Discussion Paper No. 200907). Makati, Philippines: Philippine Institute for Development Studies. Retrieved from http://www3.pids.gov.ph/ris/dps/pidsdps0907.pdf

Robles, M. (2011). Price transmission from international agricultural commodity markets to domestic food prices: Case studies in Asia and Latin America. International Food Policy Research Institute. Retrieved from http://www.nepad.org/system/files/Price_Transmissionin_LAC_Asia.pdf

Rufino, C. (2011). Analyzing the Philippines Inter-Regional Market Integration for Rice. International Research Journal of Finance and Economics, (69), 108-127.

Sachs, J. (2008, June). Surging Food Prices Mean Global Instability. Scientific American. Retrieved from http://www.scientificamerican.com/article.cfm?id=surging-food-prices

Samson, C. R., Mataia, A. B., \& Francisco, S. R. (2010). Spatial analysis of price transmission efficiencies in Philippine rice market. In Philippine Journal of Crop Science (Vol. 35, p. 122). Davao, Philippines: Crop Science Society of the Philippines.

Sanogo, I. (2008). Spatial integration of the rice market: empirical evidence from mid-west and farwest Nepal, and the Nepalese-Indian border. Asian Journal of Agriculture and Development, $4(1), 139-156$.

Sanogo, I., \& Maliki Amadou, M. (2010). Rice market integration and food security in Nepal: The role of cross-border trade with India. Food Policy, 35(4), 312-322. doi:doi: 10.1016/j.foodpol.2010.03.002

Sarris, A., Conforti, P., \& Prakash, A. (2011). The use of organized commodity markets to manage food import price instability and risk. Agricultural Economics, 42(1), 47-64. doi:10.1111/j.1574-0862.2010.00463.x

Schuttel, C., Kleinwechter, U., Ihle, R., \& Grethe, H. (2011). Domestic policy responses to the food price crisis: the case of Bolivia. Journal of Agriculture and Rural Development in the Tropics and Subtropics, 112(2), 125-139.

Seck, P. A., Tollens, E., Wopereis, M. C. S., Diagne, A., \& Bamba, I. (2010). Rising trends and variability of rice prices: threats and opportunities for sub-Saharan Africa. Food Policy, 35(5), 403-411. doi:doi: 10.1016/j.foodpol.2010.05.003

Siddig, K., \& Grethe, H. (2014). International price transmission in CGE models: How to reconcile econometric evidence and endogenous model response? Economic Modelling, 38, 12-22. doi:10.1016/j.econmod.2013.11.038

Slayton, T. (2009). Rice Crisis Forensics: How Asian Governments Carelessly Set the World Rice Market on Fire (CGD Working Paper No. 163). Washington, D.C.: Center for Global Development. 
Slayton, T., \& Timmer, C. P. (2008). Japan, China and Thailand Can Solve the Rice Crisis-But U.S. Leadership Is Needed. Washington, D.C.: Center for Global Development.

Timmer, C. P. (2010a). Reflections on food crises past. Food Policy, 35(1), 1-11. doi:doi: 10.1016/j.foodpol.2009.09.002

Timmer, C. P. (2010b). The Changing Role of Rice in Asia's Food Security (ADB Sustainable Development Working Paper No. 15). Metro Manila, Philippines: Asian Development Bank (ADB). Retrieved from http://www.adb.org/documents/papers/adb-working-paper-series/adbwp15-rice-food-security.pdf

Trostle, R. (2008). Global Agricultural Supply and Demand: Factors Contributing to the Recent Increase in Food Commodity Prices (WRS No. 0801). United States Department of Agriculture. Retrieved from http://www.ers.usda.gov/Publications/WRS0801/WRS0801.pdf

Trung, L. D., Tam, T. N. M., Baulch, B., \& Hansen, H. (2007). Testing for food market integration: a study of the Vietnamese paddy market (DEPOCEN Working Paper No. 2007/11).

Development and Policies Research Center. Retrieved from http://www.depocenwp.org/upload/pubs/LeDangTrung/Testing\%20for\%20Food\%20market\% 20integration_DEPOCEN.pdf

USDA Agricultural Research Service. (2012). Rice Quality Categories. Retrieved from http://www.ars.usda.gov/Research/docs.htm?docid=7060

Varela, G. (2012). Incomplete, Slow, and Asymmetric Price Transmission in Ten Product Markets of Bolivia (Policy Research Working Paper No. 6291). Latin America and the Caribbean Region: World Bank.

Varela, G., Aldaz-Carroll, E., \& Iacovone, L. (2012). Determinants of Market Integration and Price Transmission in Indonesia (No. 6098). World Bank. Retrieved from http://elibrary.worldbank.org/doi/pdf/10.1596/1813-9450-6098

Von Braun, J. (2008a). Responding to the World Food Crisis: Getting on the Right Track. Washington, DC: International Food Policy Research Institute. Retrieved from http://www.ifpri.org/publication/responding-world-food-crisis-getting-right-track

Von Braun, J. (2008b). The food crisis isn't over. Nature, 456(701). doi:10.1038/456701a

Von Braun, J., \& Tadesse, G. (2012). Global Food Price Volatility and Spikes: An Overview of Costs, Causes, and Solutions (No. 161). Bonn, Germany: Center for Development Research (ZEF). Retrieved from http://www.zef.de/fileadmin/media/news/1a7f_zef_dp_161.pdf

Wang, K.-M., \& Lee, Y.-M. (2009). A measure of marketing price transmission in the rice market of Taiwan. Zbornik Radova Ekonomski Fakultet U Rijeka, 27(2), 311-311-326.

Warr, P. (2008). The transmission of import prices to domestic prices: an application to Indonesia. Applied Economics Letters, 15(7), 499-503.

WB. (2012). Food Price Volatility a Growing Concern, World Bank Stands Ready to Respond. Retrieved from http://www.worldbank.org/en/news/press-release/2012/07/30/food-pricevolatility-growing-concern-world-bank-stands-ready-respond

World Bank. (2008). Rising Food Prices: Policy Options and World Bank Response. Washington, DC: World Bank. Retrieved from http://siteresources.worldbank.org/NEWS/Resources/risingfoodprices_backgroundnote_apr08 .pdf 


\section{Nelissa Jamora}

\section{Education}

2011-2014 PhD Agricultural Economics

Georg-August-Universität Göttingen, Germany

2004-2006 MS Agricultural Economics

Michigan State University (MSU), USA

Specialization in International Development

Center for Advanced Study of International Development, MSU

1997-2000 BS Economics

University of the Philippines, Los Baños, Philippines

\section{Awards}

2014-2015 Academic career support grant, German Research Foundation

2014

Young Rice Scientist at the $4^{\text {th }}$ International Rice Congress

2004-2006

Fulbright-Philippine Agricultural Scholarship Program to the U.S. 